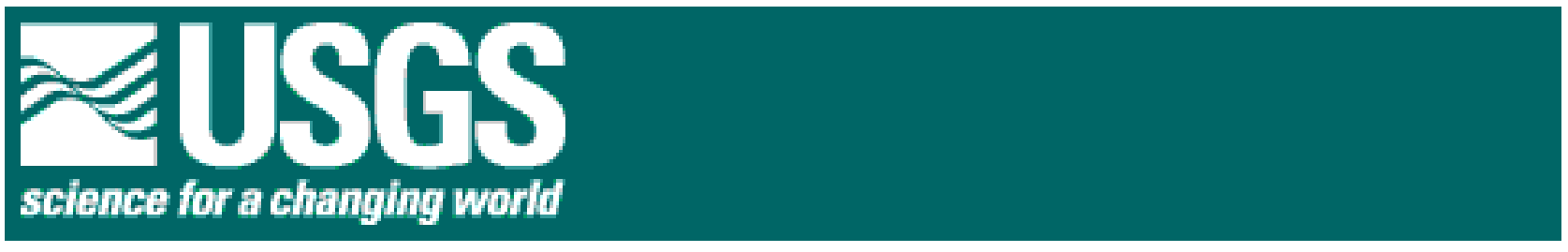

Mammal Inventory of the Mojave Network ParksDeath Valley and Joshua Tree National Parks, Lake Mead National Recreation Area, Manzanar National Historic Site, and Mojave National Preserve

Charles A. Drost and Jan Hart

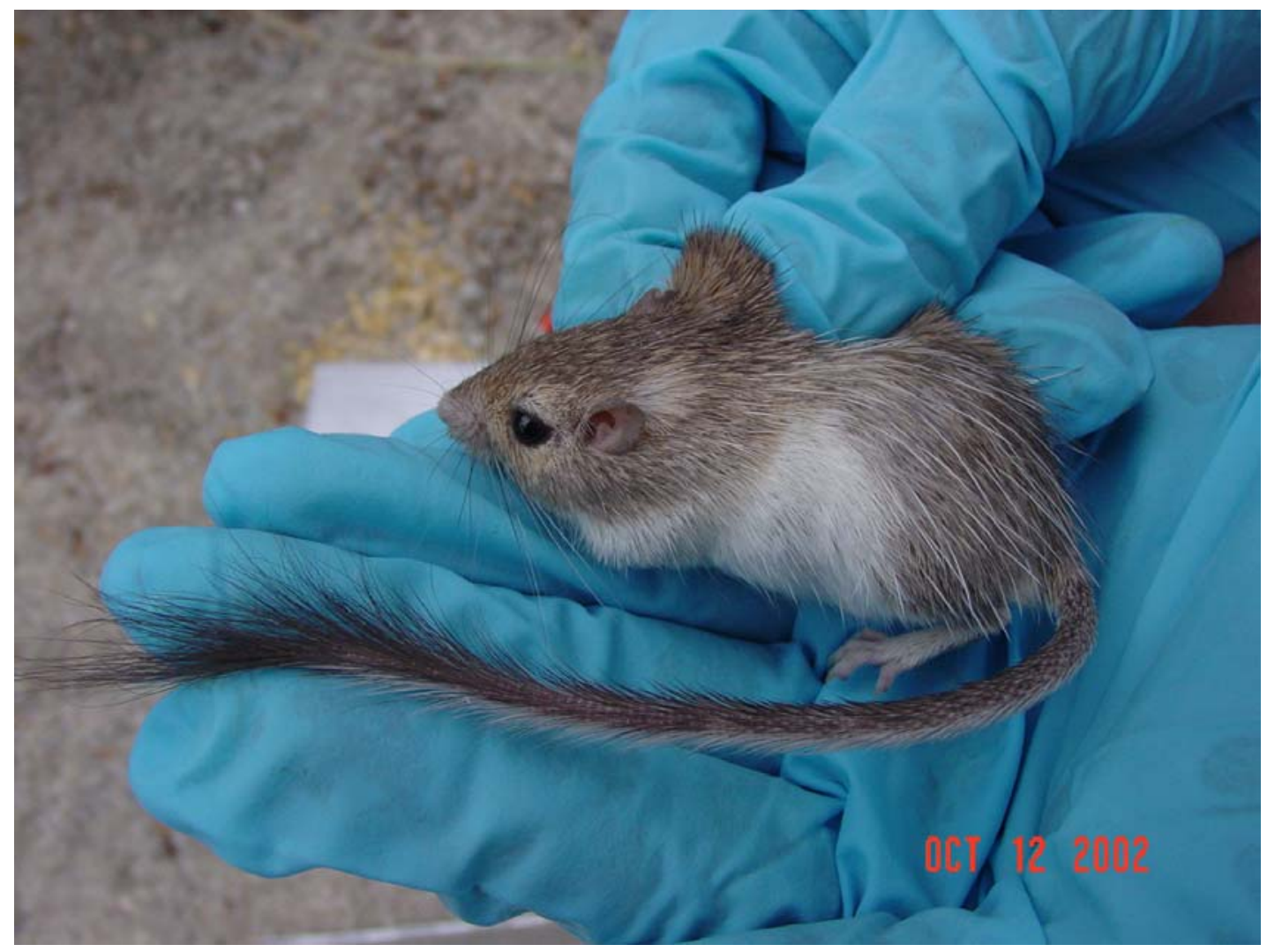

Open-File Report 2008-1167 


\section{U.S. Department of the Interior \\ DIRK KEMPTHORNE, Secretary}

\section{U.S. Geological Survey \\ Mark D. Myers, Director}

U.S. Geological Survey, Reston, Virginia 2008

For product and ordering information:

World Wide Web: http://www.usgs.gov/pubprod

Telephone: 1-888-ASK-USGS

For more information on the USGS - the Federal source for science about the Earth, its natural and living resources, natural hazards, and the environment:

World Wide Web: http://www.usgs.gov

Telephone: 1-888-ASK-USGS

Suggested citation:

Drost, Charles A., and Hart, Jan, 2008, Mammal inventory of the Mojave Network parks; Death Valley and Joshua Tree National Parks, Lake Mead National Recreation Area, Manzanar National Historic Site, and Mojave National Preserve: U.S. Geological Survey Open-File Report 2008-1167, 74 p.

Any use of trade, product, or firm names is for descriptive purposes only and does not imply endorsement by the U.S. Government.

Although this report is in the public domain, permission must be secured from the individual copyright owners to reproduce any copyrighted material contained within this report. 


\title{
Mammal Inventory of the Mojave Network Parks: \\ Death Valley and Joshua Tree National Parks, Lake Mead National Recreation Area, Manzanar National Historic Site, and the Mojave National Preserve
}

\begin{abstract}
This report describes the results of a mammal inventory study of National Park Service units in the Mojave Desert Network, including Death Valley National Park, Joshua Tree National Park, Lake Mead National Recreation Area, Manzanar National Historic Site, and Mojave National Preserve. Fieldwork for the inventory focused on small mammals, primarily rodents and bats. Fieldwork for terrestrial small mammals used trapping with Sherman and Tomahawk small- and medium-sized mammal traps, along with visual surveys for diurnal species. The majority of sampling for terrestrial small mammals was carried out in 2002 and 2003. Methods used in field surveys for bats included mist-netting at tanks and other water bodies, along with acoustic surveys using Anabat. Most of the bat survey work was conducted in 2003. Because of extremely dry conditions in the first two survey years (and associated low mammal numbers), we extended field sampling into 2004, following a relatively wet winter. In addition to field sampling, we also reviewed, evaluated, and summarized museum and literature records of mammal species for all of the Park units.

We documented a total of 59 mammal species as present at Death Valley National Park, with an additional five species that we consider of probable occurrence. At Joshua Tree, we also documented 50 species, and an additional four "probable" species. At Lake Mead National Recreation Area, 57 mammal species have been positively documented, with 10 additional probable species. Manzanar National Historic Site had not been previously surveyed. We documented 19 mammal species at Manzanar, with an additional 11 probable species. Mojave National Preserve had not had a comprehensive list previously, either. There are now a total of 50 mammal species documented at Mojave, with three additional probable species.

Of these totals, 23 occurrences are new at individual park units (positively documented for the first time), with most of these being at Manzanar. Noteworthy additions include western mastiff bat at Joshua Tree, house mouse at a number of wildland sites at Lake Mead, and San Diego pocket mouse at Mojave National Preserve. There are also species that have been lost from the Mojave Network parks. We discuss remaining questions, including the possible occurrence of additional species at each park area (most of these are marginal species whose distributional range may or may not edge into the boundaries of the area). Taxonomic changes are also discussed, along with potential erroneous species records.
\end{abstract}




\section{Mammal Inventory of the Mojave Network Parks}

\section{Introduction}

One of the major purposes of the U. S. National Park Service (NPS) is to protect and preserve the plants, animals, and biological communities of the federal lands that the agency manages. This is stated in the founding legislation, which describes the mission of the Park Service as “...to conserve the scenery and the natural and historic objects and the wildlife therein..." of National Park lands (National Park Service Organic Act 1916). As a fundamental part of this mission, NPS policy explicitly recognizes the important need for basic inventory data of natural resources. NPS management policies state: "The National Park Service will assemble baseline inventory data describing the natural resources under its stewardship and will monitor those resources at regular intervals to detect or predict changes” (NPS Management Policies 4:4 1988). For a nationwide network of parks, monuments, historic sites, recreation areas, and other lands, however, practice is more difficult than policy. Even large, well-known parks, such as Grand Canyon, Yosemite, and Death Valley, are deficient in some aspects of basic inventory data, and many small NPS areas have received very little study at all (Stohlgren and Quinn 1992).

The National Park Service (NPS) renewed its focus on natural resource inventory and monitoring in 1992 with the creation of a Service-wide Inventory and Monitoring Program. In fiscal year 2000, NPS initiated a nation-wide program to inventory vertebrates and vascular plants within all park areas that have significant natural resources. As part of this effort, all Park Service lands were divided into 32 groups or "networks," based on geographical proximity and similar habitat types. The several NPS units in the Mojave Desert area of southern California and adjacent Arizona and Nevada were assigned to the Mojave Network. Staff affiliated with the Mojave Network, in turn, brought together working groups of NPS managers, natural resources specialists, and outside cooperators to develop an inventory plan. This plan included reviews of existing knowledge, an evaluation and prioritization of inventory needs for vertebrates and vascular plants, and development of methodologies for conducting, evaluating, and reporting inventory work.

Of the seven NPS units included in the Mojave Network, three (Death Valley National Park, Joshua Tree National Park, and Manzanar National Historic Site) were given a high priority for mammal inventory (high priority was defined as existing inventory being less than 65\% complete), and two (Lake Mead National Recreation Area and Mojave National Preserve) were listed at medium priority for mammal inventory (defined as existing inventory being 66 - $87 \%$ complete). The network plan identified all of these areas as needing additional basic inventory work (surveys to determine overall species composition, as well as to provide general information on distribution and relative abundance). Small mammals were noted as specific priorities for all areas. This included rodents and shrews and, for Joshua Tree and Mojave, bats. This report describes the specific methods and results of inventory work on mammal species at the Mojave Network parks, evaluates the current state of inventory completeness, and discusses the mammal communities, with particular emphasis on protection and management. 


\section{Study Areas}

\section{Death Valley National Park}

Death Valley National Park is located in the northern Mojave Desert in Inyo County in eastcentral California, with a small portion of the Park extending into adjacent Nevada. The area was originally set aside as a National Monument in 1933. Subsequent additions - most recently the California Desert Protection Act in 1994, doubled the original size of the area, to its current extent of approximately 1.37 million ha (3,396,000 acres; NPS 2002). The purpose of the Park is to protect and preserve the natural, scenic, and geological features of this world-renowned desert landscape.

Physiographically, Death Valley National Park encompasses low-lying valleys bordered by hills and high mountains. Elevation ranges from -86 m (-282 ft.) at Badwater in Death Valley (the lowest point in North America), to 3,368 m (11,049 ft.) at the top of Telescope Peak in the Panamint Range. In between the extremes of the playas and the rugged mountain ridges and peaks, the Park includes several large dune systems, isolated freshwater marshes, and protected riparian strips (National Park Service 2002a). Because of the elevational range of the mountains, and because of the area's location near the transition from the Mojave Desert to the Great Basin Floristic Province, the Park is floristically diverse (Baldwin et al. 2002). Habitats range from a variety of desert scrub habitats at the low elevations, to limber pine forests on the higher mountains. This wide range of habitats, in turn, supports a wide diversity of animal species.

Recognized threats and management concerns range from aggressive non-native plant species and disturbance associated with past mining activity, to broad regional concerns over air pollution and depletion of ground water in the dry desert environment.

There have been several important studies on the mammal fauna of this area, including studies within the original Death Valley National Monument, and of lands now included within Death Valley National Park. Important early studies included the surveys of Merriam (1893) and Grinnell (1937), which focused on Death Valley itself (specifically concentrating on areas below sea level), and Miller (1946), who sampled pinyon pine habitats within the Park. More recent studies have examined specific areas, including Saratoga Springs (Bradley and Deacon 1971), and the Grapevine Mountains (Kingsley 1981),

\section{Joshua Tree National Park}

Joshua Tree National Monument was established in 1936. As with Death Valley, the California Desert Protection Act substantially increased the size of the area, and re-designated it as a National Park in 1994. The purpose of Joshua Tree National Park is to protect the desert landscape and its associated ecosystems and geological, scenic, and wildlife resources, as well as the historical and cultural resources of the Park. With the boundary expansion associated with its establishment as a National Park, Joshua Tree now encompasses approximately 321,000 ha (792,726 acres; National Park Service 1995).

Joshua Tree National Park lies astride the transition from the Mojave Desert to the Sonoran Desert Floristic Province. Several low mountain ranges further add to the physiographic and biological diversity of the area. Elevation ranges from $1.773 \mathrm{~m}(5,814 \mathrm{ft}$.) at Quail Mountain, to under $300 \mathrm{~m}$ (under 1,000 ft.) at Pinto Wash in the southeastern part of the Park. In addition to 
the mingling of Mojave and Sonoran elements, there is also coastal, "California Floristic Province" influence, due to the proximity of the Park to the higher mountains of the Transverse Ranges (Baldwin et al. 2002, Miller and Stebbins 1964).

As with other southern California park units, many of the management concerns at Joshua Tree are related to increasing levels of visitation, and the regional effects of the growth of large metropolitan areas. Urban and suburban growth are occurring directly along some of the borders of Joshua Tree, along with other ongoing and planned human developments that have the potential to negatively impact park resources.

The Joshua Tree National Park area has had a variety of inventory-related studies in the past. Particularly noteworthy is the work of Miller and Stebbins (1964) on the "lives of desert animals" of the Joshua Tree area. Subsequent surveys, studies, and compilations have added to our understanding of the vertebrate fauna of the Park, including those of De Lisle (2002), Rainey (1965), and Sakai and Hogg (1999).

\section{Lake Mead National Recreation Area}

Lake Mead National Recreation Area represents an expansion of the area originally designated as the "Boulder Dam Recreation Area" in October 1936. The Recreation Area boundaries have been expanded and modified a number of times, most recently in 1974, and the name was changed to Lake Mead National Recreation Area in 1964. The Recreation Area in its present form takes in over 600,000 ha (1.5 million acres), along the Colorado River in northeastern Arizona and southernmost Nevada (Lake Mead National Recreation Area 2001, National Park Service 2000).

Lake Mead National Recreation takes in the lands bordering the Colorado River from the Grand Wash Cliffs at the western end of Grand Canyon National Park, downstream to Davis Dam at the south end of Lake Mohave. It also includes the highlands of the Shivwits Plateau along the north side of the western Grand Canyon. Elevation ranges from $191 \mathrm{~m}$ (ca. $628 \mathrm{ft}$.) at Davis Dam to 2,156 m (7,072 ft) at Mount Dellenbaugh on the Shivwits Plateau. Plant and animal habitats within the Recreation Area range from Mojave and Sonoran Desert at the lower elevations, to ponderosa pine forest at the higher elevations on the Shivwits Plateau, with riparian and other wetlands habitats along the river, tributary streams, and other areas of water.

Information on the mammals and other terrestrial vertebrates of Lake Mead National Recreation Area was summarized by Schwartz et al. (1978), in a National Park Service Technical Report. This report drew on previous surveys and museum specimen compilations for the vicinity, notably Hoffmeister and Durham (1971) and Hall (1946). Suttkus et al. (1978) provide information on mammals along the Colorado River corridor, including the upper part of Lake Mead.

\section{Manzanar National Historic Site}

Manzanar National Historic Site is the 'newest' of the Mojave Network park units: The site was established in 1992 to preserve and interpret for the public the Japanese American internment camp that was built at this location and housed approximately 10,000 Japanese American 
citizens during World War II. The Historic Site is located in the Owens Valley of eastern California, between the towns of Independence and Lone Pine. Although the land area of the entire relocation facility was much larger, Manzanar encompasses the core area of approximately 330 ha (814 acres).

The Owens Valley where Manzanar is located is a long, flat basin walled in by the Inyo Mountains on the east and the Sierra Nevada on the west. Manzanar is at the foot of the gentle slope leading down from the base of the Sierras, along Bairs Creek. The site is relatively flat, ranging in elevation from ca. 1,170 $\mathrm{m}$ (3,830 ft.) to 1,210 $\mathrm{m}$ (3,970 ft.). The most extensive vegetation type at the site is desert scrub, dominated by saltbush, rabbitbrush, and sagebrush. There are also sizable areas of cottonwood / willow / tamarisk riparian vegetation along Bairs Creek, and a large woodland grove that includes cottonwoods, locusts, willows, and orchard trees.

No previous inventory studies have been conducted directly in or around Manzanar. However, useful information for the fauna of the site is provided by museum specimen records from the Owens Valley as a whole, and reports and literature that cover all or part of the area. A useful general guide to the natural history of the area is Putman and Smith (1995).

\section{Mojave National Preserve}

The Mojave National Preserve was established by the California Desert Protection Act in 1994. The Preserve superseded the East Mojave National Scenic Area, which was created in 1981. It is located in eastern San Bernardino County, and is largely bounded on the north by Interstate Highway 15, and on the south by Interstate 40 (with the exception of the Clark Mountain section, located north of Interstate 15). The Preserve is approximately 650,000 ha (1.6 million acres) in extent, and ranges in elevation from about $283 \mathrm{~m}$ (са. $928 \mathrm{ft}$.) at Saline Lake to $2417 \mathrm{~m}$ (7929 ft.) at the top of Clark Mountain (National Park Service 2002b).

Like other of the Mojave Network park units, the plant and animal diversity of the desert expanse of Mojave National Preserve is augmented substantially by several mountain ranges that rise up across the Preserve, including the Granite Mountains, Providence Mountains, and New York Mountains. The Clark Mountain Range is in a separate section of the Preserve on the north side of Interstate Highway 15.

Some survey studies have examined particular parts of the area included within Mojave National Preserve, and several research projects have studied the ecology of individual mammal species or groups of species within the Preserve boundaries. Important survey studies include Johnson et al. (1948) and Stein and Warrick (1979).

\section{Objectives}

This study is a part of the National Park Service's Inventory and Monitoring Program, whose broad goal is to establish baseline resource conditions for all units of the Park Service that have significant natural resources (National Park Service 1999). General objectives for NPS inventories are to:

1. Document through verifiable data the occurrence of at least $90 \%$ of the vascular plant and vertebrate species that are likely to occur in the park. 
2. Describe the distribution and relative abundance of species of special concern, such as listed threatened and endangered species, non-native species, and other species that are particularly important according to park resource management plans.

3. Provide baseline information to develop monitoring strategies and park-specific protocols for long-term monitoring” (National Park Service 1992).

The size and complexity of the parks in the Mojave Network pose significant challenges to obtaining distribution and abundance information or contributing information that would be useful in the development of monitoring protocols. For all of the Mojave Network parks except for Manzanar, park managers expressed needs for targeted inventories of specific locations or habitat types that were previously unexplored or relatively poorly-known, rather than a systematic, park-wide inventory design. In addition, because of the large size and diverse landscapes of the large Mojave parks, it was not considered feasible to attempt park-wide, systematic inventories. Again, the one exception was the Manzanar area, which was much more manageable in size.

Following from the goals of the Mojave Network plan, the overall goal of the mammal inventory at the Mojave parks was to determine the mammal species composition of the area to at least a $90 \%$ level of completeness. Other goals of the survey were to provide: (1) distribution and relative abundance data for mammal species; (2) summaries of biological and natural history information yielded by the survey work; (3) spatial data on sampling site locations and associated mammal sampling data for incorporation into the GIS of each park; (4) museum voucher specimens, as appropriate; and, (5) recommendations for long-term monitoring of mammals, based on the inventory results.

Also, where possible, inventories were designed to provide as much information as possible on the distribution and abundance of species of special concern, including rare species, and nonnative species.

\section{Methods}

\section{Museum Search}

Over the course of this project, we reviewed records from regional museums for mammal specimen collected in or near the Mojave Network parks. Most of the major museums had records in electronic databases, and we requested and obtained copies of data from all counties in California, Arizona, and Nevada where the Mojave parks are located (museum records typically list the county where the specimen was collected, and this is the most thorough and efficient way to obtain records from an area). In a few instances, museum records were not available in electronic form. In these cases, we created database files and entered pertinent records directly. Records from all museums were converted to a common database format for ease of reviewing and handling the records. Once it was compiled, we reviewed the data for errors, name changes, and any other problems. We then went through the data record by record and marked those records that were in or near any of the Mojave Network parks. Finally, these records were 
summarized and tabulated by park. In a few cases, we checked locations in the field, or consulted the individual museums to verify identifications or to attempt to obtain more precise location information.

\section{Field sampling}

Field sampling focused on small mammals, primarily rodents. We also surveyed for mediumsized mammals, including small carnivores, and at Joshua Tree and Mojave, we surveyed for bats (the other areas did not want surveys of bats). Even with this relatively restricted range of species, there are different sampling methods, which are more or less effective for different groups. For this reason, we employed several different techniques to adequately inventory the mammal fauna, and provide baseline population information. All methods and sampling procedures that we used are approved by the American Society of Mammalogists (Gannon et al. 2007), and follow ASM guidelines for proper treatment of animals in research.

Most of our field sampling was conducted within the priority study areas (Table 1) identified by each park unit. Within the priority study areas, we selected sites based on the particular species or species groups that we were targeting for that area. In other words, the specific sites that field crews chose for deploying traps or conducting other surveys were based on species habitat requirements, and field evaluation of habitats within the general area. At all sampling sites, we recorded data on vegetation cover and physical habitat parameters, so that habitat at the site could be categorized using community-type keys or descriptions.

\section{Trapping}

Nocturnal small mammals (rodents, shrews): We used small grids or transects of live traps (H. B. Sherman Co.) to sample nocturnal small mammals (Jones et al. 1996). These were supplemented in a few areas with pitfall traps. "Sherman" traps are effective for most rodent species, while pitfall traps are useful for shrews and for some rodents (such as voles, Microtus spp.) that are not prone to entering box traps. Traps were deployed in one of two ways:

(1) In transects, typically consisting of 10 stations spaced 15 m apart, with two traps per station, for a total of 20 traps. In targeted sampling situations, the transects were deployed to follow the habitat or feature of interest (e.g. narrow riparian area along stream courses, or the base of cliffs or rock outcrops).

(2) In small $3 \times 3$ grids, with traps placed $15 \mathrm{~m}$ apart. Such grids were used in habitats that are relatively uniform across the landscape (i.e. that are not linear or irregularly distributed);

We baited Sherman traps with rolled or crimped oats, or a combination of oats and peanut butter. Traps were set in the evening, and checked early the following morning, so that captured animals were not exposed to the full heat of the sun.

Pitfall traps, when used, were not baited. Pitfall traps consisted of 5-gallon buckets sunk in the ground so that the top edge of the bucket was flush with the ground surface. All pitfalls were covered by a shade board to keep out sun and rain. Pitfall traps were generally checked once per day when they were open, although timing of the check was not as critical as with Sherman traps. Sherman traps were retrieved at the end of each trap session, and pitfall traps were securely closed with a tight-fitting lid when they were not in use. 
We identified trapped animals to species, weighed and measured them, and recorded age and reproductive status. Usual measurements included body length, tail length (with and without the terminal tuft of hairs), hind foot length, and ear length (measured from notch to tip). We took digital photographs of rare or unusual species whenever possible.

Trapping effort was recorded as the number of traps set, times the number of nights the traps were open (referred to as number of 'trap-nights'). Traps that were noted as non-functional when they were checked, were subtracted from the total number of traps available for that night. All small mammal trapping incorporated recommended precautions to minimize exposure to hantavirus and other mammal-borne diseases.

Diurnal small and medium-sized mammals. We surveyed diurnal mammals using visual searches and by trapping with Sherman traps or wire-type box traps ("Havahart," or “Tomahawk"). Traps for diurnal mammals were generally set out in short transects or small groups in the particular habitat of interest. All traps set during the day were placed in shady sites, or were provided with artificial shade, in the form of a cover board propped over the top of the trap. Traps set during the day were checked frequently while they were open (e.g. hourly), to prevent overheating of captured individuals. As with traps set at night, trap effort was quantified as number of 'trapdays.'

\section{Visual surveys}

We conducted surveys and counts of diurnal species by walking through areas of habitat in the morning and afternoon, for defined time periods (30 minutes to one hour per area). We identified all animals seen, and recorded notes on species, location (recorded with GPS), time, general habitat type, and specific microhabitat, as appropriate. We took photos of these species, when possible, with cameras with telephoto lenses. Other mammal sign (tracks, scat, digging) were also recorded during these visual area surveys. In addition to standardized visual surveys, field staff also noted other diurnal mammals seen incidentally during the course of other fieldwork (e.g. while enroute to trapping sites). Where appropriate, similar data were recorded for these 'random encounters' (date, time, species, habitat, GPS location, etc.)

\section{Automatic cameras}

We used two different automatic camera systems to "capture" medium-sized nocturnal mammals (Wemmer et al. 1996). These included the active infrared "Trailmaster" system, which uses an infrared transmitter and receiver and a modified film camera, and the "Reconyx" system, which uses a passive infrared motion detector and an associated digital camera. Both camera systems have a date / time stamp that records the date and time of each event (when the motion detector is tripped) directly on the photo. We deployed these camera units along game trails or other areas where animal traffic was funneled (e.g. a narrow canyon, or an opening in vegetation). In most cases we set out bait or scent attractants in the "viewing area" of the camera and infrared detector. Field crews usually set up camera traps in late afternoon when they arrived in an area, and retrieved the unit the following morning. We generally did not stay at sampling sites more than one night, so the usual sampling effort was one "camera night” per site. 


\section{Sign}

We collected supplemental information on occurrence, distribution, and habitat use of small and medium-sized mammals by recording information from tracks, scat, dens, burrows and diggings. Field crews looked for mammalian sign whenever they were in the field, day or night. When they found identifiable sign, they recorded species (if this could be determined), location, habitat, and nature and condition of sign. Where particularly interesting or pertinent sign was found, it was collected, photographed (tracks, burrows), or traced onto clear acetate (tracks). We referred to standard identification guides (Halfpenny 1986, Murie 1974) to identify and interpret different sign that we found. Species identification is not always possible, but notes on such observations provide a useful complement to data gathered by other methods.

\section{Owl pellets}

In some areas, we collected and analyzed owl pellets to identify small mammals taken by the owls. When owl roosts were found, we searched for and collected pellets (the indigestible fur and bones regurgitated by the owls) from under and around the roost. These pellets were later dissected to recover bones (particularly skulls) of small mammals (Glue 1970). Owls can be effective and thorough samplers of the small mammal fauna in an area, and bones in their pellets are generally identifiable to species. Identification of these remains provided supplemental data on small and medium-sized mammals in the area. All of the pellets we collected were known or suspected to be from Barn Owls and Horned Owls. Skulls in good condition that were recovered from owl pellets were retained for voucher purposes for the inventory.

\section{Methods for Bats}

Because of their nocturnal nature, wide-ranging flight habits, and generally secretive roosting behavior, bats pose special challenges for inventory studies. There are a number of specialized survey methods for bats, including mist netting and harp traps, and roost surveys. Particularly for temperate North American bat species, however, the most effective and cost-efficient survey method consists of ultrasonic surveys of the echolocation calls emitted continuously by bats when they are active at night. Ultrasonic surveys have some important advantages as compared to mist net surveys. In particular, many bat species are difficult to capture in nets, and ultrasonic recorders are not limited to use around water and other concentration areas for bats (Thomas and West 1989). Surveys using bat call recorders frequently document a range of bat species in an area when mist net surveys turn up little or nothing, and ultrasonic surveys have been shown to be particularly useful for rare, widely ranging species (Drost et al. 2000, Fenton et al. 1987).

The recorder that we used in this project was the Anabat II bat detector, a countdown type recorder designed specifically for identifying microchiropteran bats by the pulse rate and time pattern of the dominant frequency of their calls (Hayes and Hounihan 1994, Fenton 1988). Most of our Anabat surveys were stationary surveys with the Anabat / computer system used in conjunction with mist net surveys (described below). We generally set up the computer and Anabat at or near dusk, and recorded continuously for two to four hours. The amount of time 
depended on the level of activity at the site (or lack thereof) and whether we planned to visit additional sites that evening. The person handling the Anabat typically swept it back and forth and around overhead, until calls were detected. At that point, an effort was made to "lock on" to the direction of the bat, to assure that a good sequence of calls was recorded. The recorder also used a hand-held spotlight to try to see the bat at this point. Flight patterns, and in some cases patterns of light and dark on the bat, are useful for confirming the identification of a particular bat. Output from the Anabat was directed to a laptop computer, both for immediate display and identification of the calls, and for permanent storage to the computer hard drive. Anabat call files are automatically recorded with a date / time stamp. We recorded separate notes on time, species identification and behavior, when particularly interesting species were recorded. In addition to allowing identification of bats visiting an area (such as a stock tank or similar water body), the stationary surveys also allowed us to make verified reference calls of different bat species captured in the nets. For this purpose, captured bats were released in a relatively clear, open area in front of the Anabat setup, and the person handling the Anabat kept the recorder trained on the released bat until it flew out of recording range.

We also conducted surveys from a vehicle, with one driver and one recorder handling the Anabat. These surveys incorporated real-time GPS, with UTM locations recorded for each bat species detected by the Anabat. As with stationary surveys, calls were displayed and recorded on a laptop computer. We also calculated species by species activity rates for Anabat surveys. It is typically not possible to determine if Anabat call sequences represent many different individuals, or one or a few individuals flying back and forth through an area. For this reason, we refer to tabulations of call sequences as measures of activity, as opposed to strict measures of abundance. For purposes of this survey, we tabulated calls separated by at least 10 minutes, to produce a relative measure of activity over the course of the evening. In cases where two or more bats were definitely recorded (either visually, or in the call sequence), the additional bats within the time period were added to the total. Some bat species produce echolocation calls audible to the human ear (e.g. mastiff bat, spotted bat). Since these low-frequency calls were sometimes not recorded by Anabat (which is tuned for higher frequencies), we counted and tabulated these species separately as the number of bats heard, their location, and the time they were heard.

All Anabat call sequences were confirmed by Chris Corben, who has extensive experience with identification of western United States bats and their echolocation calls. Chris developed both hardware and software for the Anabat system, and is uniquely qualified in the general use of the system, its features, and limitations. The bat call data are annotated with notes on call characteristics, behavior and appearance of the bats (if they were seen), and any questions about individual identifications.

At selected sites we also conducted mist net surveys. These sites were at areas of open surface water, areas near mine openings or other potential roost sites, or areas where canyon walls or lanes in vegetation tended to funnel the flight of bats. Sites with water are typically good sites for capturing bats in mist nets, particularly in arid desert regions, where they must come to such sites to drink. At each site, we set up at least three or four mist nets along the edge of or across the water, or across potential flight lanes in areas without water. We generally set up nets just before dusk, and kept them open until 10:00 to 11:00 pm. Nets were attended by one or two field crew at all times, so that bats could be removed and processed as soon as they entered the 
net. Captured bats were identified, sexed, and (for females) checked for reproductive condition. Basic measurements were recorded, including forearm, foot, tail, and ear. We took photographs of all species captured, showing diagnostic identifying characters whenever possible. As noted, we also released some captured individuals in front of an Anabat setup to obtain verified vocalizations. This was considered particularly important for some species (e.g. particular Myotis spp.) whose calls are very similar to one another. Bats were released promptly once we finished processing them.

Mist net locations were recorded with GPS for incorporation of the associated data into spatial databases. Data recorded for each net site included general habitat features of the site (topographic position, vegetation type, presence and character of water in the vicinity), weather conditions, bat species captured, numbers, and breeding status of individuals captured.

Combined data from Anabat recordings and mist net captures were used to evaluate bat species composition in the area surveyed, relationship to habitat parameters (vegetation type, elevation), and relative abundance. Relative abundance / activity measures were calculated separately using the Anabat recordings.

\section{Assessment of Inventory Completeness}

We used a modified 'master species list' approach to assess completeness of mammal inventory at the different parks in the Mojave Network. At the outset of this study, we compiled hypothetical species lists for each park unit (see Appendices 1 - 5). These lists included both known, documented species at each area, and species that occurred in the general area (based on regional references such as Jameson and Peeters 2004 and Hall 1946) and were judged to potentially occur within the park boundaries. Potential species were further categorized as high potential (very likely to be present in the park), medium potential (intermediate probability) and low potential (very unlikely to be present). Species that were positively documented from a park unit were given a weight of 1 . High-probability species received a weight of 0.83 , mediumprobability species were given a weight of 0.5 , and low-probability species received a weight of 0.17 (see Persons and Nowak 2005). These weighted values were then used to calculate a likely total number of mammal species for each area. At the completion of the study, we calculated inventory completeness for each area as the number of species positively documented for the area, as a percent of the weighted master species list total.

\section{Voucher Specimens}

We collected only a small number of representative specimens from the groups included in this survey. Good quality photographs were used in lieu of, or in addition to, museum study skins as vouchers for species occurrence at the different park areas. This was especially the case for larger mammals, and for relatively rare species. All specimens collected were documented and curated following NPS standards (National Park Service, 1999). Most of the voucher specimens that we collected were incidental trap mortalities, or specimens that were found dead (e.g. good condition road-killed individuals). 


\section{Taxonomy}

In the tables and text that follow, taxonomy and scientific names and common names follow Baker et al. (2003; see also Reid 2006). Some of these names and taxonomic opinions differ from the National Park Service NPSpecies “master” databases, and the on-line Integrated Taxonomic Information System (ITIS; http://www.itis.gov/) lists on which the NPS lists are based. ITIS does provide a very useful resource in its comprehensive lists of plant and animal names, but for mammals, at least, it is somewhat incomplete, and lags behind current usage. For example, it does not recognize Myotis ciliolabrum, the western small-footed myotis, which is distinct morphologically, biochemically, and geographically from M. leibii (the name that ITIS and NPSpecies uses; see Holloway and Barclay 2001). Similarly, ITIS does not recognize the western yellow bat (Lasiurus xanthinus) as distinct from L. ega (the southern yellow bat), and it does not include at all the large-eared woodrat (Neotoma macrotis). From a conservation and management standpoint, recognition of these species is potentially important to the Mojave Network parks.

Some taxonomic changes have been proposed since the publication of Baker et al. (2003) and Reid (2006). For example, Hoofer et al. (2006) proposed the new genus Parastrellus for pipistrelle bats in North America. "Canyon bat" has been proposed as an alternative common name.

Some areas - notably Mojave National Preserve and Joshua Tree National Park -- have prepared extensive lists including subspecies-level taxa (see NPSpecies data for Mojave NP, and De Lisle 2002 for Joshua Tree). In general, however, we did not address mammal subspecies, for several reasons. Few mammal subspecies are identifiable in the field, and we would have to rely solely on the range maps of other (often outdated) sources for subspecies names. Even using detailed measurements and multivariate analyses, many named subspecies can only be identified based on average characters across a population (i.e. individual specimens cannot be reliably assigned to subspecies). Finally, many subspecies designations are based on old references (e.g. Hall 1946 for part of the Mojave area) and are of questionable validity. Nonetheless, some subspecies are quite generally recognized, and are important from the standpoint of conservation (e.g. the different subspecies of bighorn sheep) We have noted subspecies in some of these cases, where use of the name is generally agreed-upon.

We list and discuss some differences in nomenclature and taxonomy, particularly in cases where a familiar, long-established name has been changed, or where a taxon has a confusing history.

\section{Results}

The majority of museum data for the Mojave Network parks was gathered in the first year of the project, but review of museum and literature records continued through the duration of the study. Major fieldwork for the project was conducted in spring and fall of 2002, 2003, and 2004. We avoided fieldwork during most of the summer each year because of the extreme heat in the desert 
areas. We made some follow-up field visits in 2005 and 2006, to follow up on particular species or areas of interest.

\section{Museum records}

We found pertinent specimen records for one or more of the Mojave Network parks at 11 museums. These included the National Park Service museums at Death Valley and Joshua Tree National Parks, as well as the California Academy of Science, the Museum of Northern Arizona, the Museum of Santa Monica College, the Museum of Vertebrate Zoology at the University of California at Berkeley, the Natural History Museum of Los Angeles County, the San Diego County Natural History Museum, the United States National Museum of Natural History in Washington, DC, the University of Arizona Museum, and the University of Illinois Museum of Natural History. We reviewed over 7,200 specimen records from the counties in and around the five Mojave Network parks (the counties encompassing the parks are Mohave County in Arizona, Inyo, Riverside, and San Bernardino Counties in California, and Clark, Esmeralda, and Nye Counties in Nevada).

We were able to verify that just under 1,000 (996) of these museum specimen records were from within the current boundaries of the Mojave Network parks. The number of specimens varied widely for the different parks. There were 674 records representing 46 species from Death Valley National Park, 167 records of 23 species from Joshua Tree National Park, 82 records of eight species from Mojave National Preserve, and 73 records of 24 species from Lake Mead National Recreation Area (Table 2).

\section{Field Sampling Effort}

Over the main period of fieldwork for this study (2002 - 2004), we made 41 field visits and spent 396 person-days in the field at the five Mojave Network park units (Tables 3 and 4). We had 14 field sessions in 2002, 16 field sessions in 2003, and 11 sessions in 2004 (Table 3). The greatest amount of field time was involved in setting and checking small mammal traps at targeted sampling sites across each of the park units. Other activities included visual surveys for diurnal mammals, use of remote camera "traps" for medium-sized nocturnal mammals, and mistnetting and Anabat surveys for bats. Additional visits were made to the network parks in 2005 and 2006, to check background information on museum specimens and unpublished reports.

Small mammal trapping totaled over 7,300 trap nights across all five park units over the threeyear period (Table 4). Person-effort and number of trap-nights roughly paralleled the size of the different park units, ranging from over 100 person-days and nearly 2,400 trap-nights at Death Valley, to 28 person-days and just over 600 trap-nights at Manzanar (Table 4). At the parks where we surveyed for bats, we had approximately 110 hours of night survey hours (mist-netting and Anabat / acoustic surveys combined). Most of this was in 2002 and 2003.

\section{Precipitation Patterns and Effects on Mammal Numbers}

The first year of this survey, 2002, was very dry in all of the Mojave Network parks (Figure 1). Precipitation at all of the park units was one inch or less, ranging from 0.48 inches at Death Valley (compared to an annual average of 2.36) to 1.01 at Lake Mead (annual average 5.91). In 2003, rainfall in was near average at Death Valley (2.96 inches) and Lake Mead (5.24), and well 
above average at Joshua Tree (6.9 inches) and Mojave (6.58). Rainfall in 2004 was above average in all areas, ranging from 2.94 in Death Valley to 11.57 at Lake Mead. We extended field sampling into 2004 to try to take advantage of the greater precipitation, and the expected increase in numbers of small mammals. In 2004, we spent a total of 128 person-days in the field, concentrating on Mojave National Preserve (46 person-days), Joshua Tree NP (39), and Death Valley NP (36). Trap success was conspicuously higher at in 2004 at Death Valley and Joshua Tree, exceeding 50\% on some visits. Recruitment of young individuals also appeared to be markedly improved in this last year. This was the first field season where we captured significant numbers of young animals at any of the parks.

\section{Field Sampling Results}

Recent fieldwork at the Mojave Network parks recorded a total of 50 mammal species over all five units (see Tables 7 - 11). This includes trap captures (mainly rodents), mist-net captures, visual sightings, and miscellaneous records such as automatic camera placements and Anabat records. At individual parks, we recorded 16 different species at Death Valley, 25 at Joshua Tree, 21 at Lake Mead, 19 at Manzanar, and 27 at Mojave (Tables 7 through 11; the totals do not sum to 50, of course, because many of the same species were recorded at more than one unit). These totals include both the groups that we specifically targeted (rodents and other terrestrial small mammals at all areas, and bats at Joshua Tree and Mojave), and also all other species that we recorded with other survey techniques (e.g. infrared automatic cameras) and that we observed incidentally in the course of other fieldwork.

Total captures for each park, across all sampling sessions, are listed in Table 6. These numbers reflect the specific habitats and geographic areas that we sampled (i.e. the 'Priority Study Areas' that were specified for each park). At Death Valley, four species of Peromyscus dominated the captures, along with the desert pocket mouse and desert woodrat. At Joshua Tree, the Merriam's kangaroo rat was abundant across all areas trapped. Large numbers of little pocket mice were also trapped, and pallid bat (Antrozous pallidus) was the most numerous bat recorded. At Lake Mead, cactus mice far outnumbered all other species in our captures; canyon mice, Merriam's kangaroo rat, and desert woodrat were captured in moderate numbers. At Manzanar, deer mice dominated the trap captures, followed by Merriam's kangaroo rats and brush mice. Finally, at Mojave National Preserve, the desert woodrat was surprisingly numerous, and was our most frequent capture. Large numbers of cactus mice, brush mice, and canyon mice were also caught.

We mist-netted for bats at Joshua Tree and Mojave. We caught six species of bats at Joshua Tree, with pallid bats by far the most numerous. Big brown bat (Eptesicus fuscus) and western pipistrelle (Pipistrellus hesperus) were a distant second in numbers. We netted a total of seven species at Mojave, with pipistrelles and California myotis (Myotis californicus) most numerous.

\section{Species lists}

Synthesizing the information from field surveys and literature and museum reviews yields current mammal species lists for the Mojave Network parks (Tables 7 through 11). In Tables 7 11, "D” indicates "Documented," or positively identified as being present within the boundaries of the park unit, either through museum specimens (M) or literature records (L) from sites within 
the boundaries of the unit, or through trap captures (C), or confirmed visual observations (S) (or some combination of these forms of evidence). Literature sources used only include those that describe captures or sightings of species at locations that were definitely within one of the park areas (i.e. they do not include sources that simply provide general range maps). Species listed as "Probably Present" are considered to have a high probability of being found within a particular park area; in many cases, these include species for which there are anecdotal reports which could not be verified. Species listed as "Unconfirmed" are less likely to be found within an area; there are sometimes reports of these species, but they are not well-documented and not considered trustworthy. The species lists do not include species listed as "False Report” in NPSpecies, or other records known to be in error; such species are based on old reports, literature, etc. that proved to be mistaken, and occurrence of these species is considered extremely unlikely.

There are a total of 59 mammal species documented from Death Valley National Park. At Joshua Tree National Park, a total of 50 species have been documented, with four additional species considered to be "Probably Present" (species thought to be present, even though there are not specimen records, photographs, or well-documented observations within or directly adjacent to Park boundaries; usually these are species that have been recorded within a few miles of Park boundaries, in habitat that occurs in the Park). At Lake Mead National Recreation Area, 59 mammal species have been documented, with eight additional "Probable" species. Manzanar National Historic Site has not had a mammal list up to now. Our preliminary list for Manzanar includes a total of 19 species that have been documented to be present, and an additional 11 "Probable" species. The list for Mojave National Preserve includes a total of 50 documented mammal species.

Species listed as "Unconfirmed" in the park species lists (tables 7 through 11) are species that have been listed in the past on hypothetical lists for the different areas, for which there is no good documentation of their occurrence in these areas; they are considered unlikely to be present because their known distributional range is not close to the monuments, and / or their habitat is different from that present in the respective areas (both the terms "Probably Present" and "Unconfirmed" are categories used in the National Park Service NPSpecies database, and we have tried to conform to their definitions).

\section{Inventory Completeness}

Using the modified 'master species list' approach, we calculated an estimated species total of 68.3 for Death Valley National Park (the decimal reflecting the use of fractional numbers for different levels of 'potential' species). Our list (Table 7) includes 59 mammal species documented for Death Valley to date. Dividing 59 by 68.3 yields an estimated inventory completeness of $86 \%$. For the other Mojave Network park areas, the calculations yield an estimated $89 \%$ inventory completeness for Joshua Tree (estimated species total $=56.3$, documented $=50$ ), $84 \%$ for Lake Mead (estimated 70.7, documented 59), 52\% completeness for Manzanar (estimated 36.6, documented 19), and 89\% estimated completeness for Mojave National Preserve (estimated species total $=56.5$, documented $=50$ ). 


\section{Species Notes}

In this section, we discuss individual mammal species records for the different park units in the Mojave Network. This includes the type of evidence for including a given species on the park list, locations described in literature or museum descriptions, new species records for the parks, known population changes, and species that have been lost from an area. We also note remaining questions about the status of particular mammal species in each park area. Species notes are listed in taxonomic order, for each park unit in the network.

\section{Death Valley National Park}

The spotted bat (Euderma maculatum) was recorded from “Hunter Canyon, Saline Valley” by its audible echolocation calls in April 1997 (Pierson and Rainey 1998). The coordinates for the location fall within the northwest boundary of Death Valley NP. Given the wide-ranging habits of this species, we feel there is good reason to list it as at least an occasional visitor to Death Valley.

The nearest records to Death Valley NP for Least Chipmunk (Neotamias minimus) are from the Inyo Mountains. We conducted visual searches specifically for this species in the northwestern area of Death Valley NP, along the east base of the Inyos. We did not find the species during our surveys, but believe there is a good chance that it occurs within the Park.

The Museum of Vertebrate Zoology has a specimen of the Golden-mantled Ground Squirrel (Spermophilus lateralis) collected at the east base of Waucoba Mountain (west of Jackass Flats). The coordinates provided for this specimen are within the boundary of Death Valley NP in this area, and we include this species on the Death Valley mammal list on this basis.

Ord's Kangaroo Rat (Dipodomys ordii) occurs in Esmeralda County, Nevada, north of the Nevada triangle of Death Valley NP (Hall 1946), and specimens have also been taken down into Owens Valley north Big Pine. We trapped the Nevada triangle area and the northernmost section of Death Valley looking for this species, but did not find it.

Small numbers of house mice (Mus musculus) have been noted by different sources in the buildings at Scotty’s Castle (e.g. Kingsley 1981). As far as we can determine, there is not a persistent population in natural habitats away from developed areas.

Characteristics gnawing and other sign of Porcupine (Erethizon dorsatum) have been noted by different authors in some areas of Death Valley - e.g. the Grapevine Mountains (Miller 1946, Kingsley 1981).

\section{Joshua Tree National Park}

We list the silver-haired bat, long-eared myotis, and western small-footed myotis as "Unconfirmed” at Joshua Tree. There are no known records of these species within the Park, but the proximity of the western end of the Park to the San Bernardino Mountains provides an easy corridor for these species to show up on an occasional basis. 
The addition of the western mastiff bat (Eumops perotis) to the mammal fauna of Joshua Tree NP is based on a specimen (previously unidentified) in the care of the Resource Management Division at the Park. This specimen has a forearm measurement of $78 \mathrm{~mm}$, the fur color is chocolate brown overall, and the upper lip is not wrinkled; all of these points clearly indicate Eumops. Brown (1993) also noted hearing this species in the vicinity of Cottonwood Springs, Barker Dam, and Keyes Ranch at Joshua Tree. She further noted that calls were heard soon after dark at Barker Dam and Keyes Ranch reservoir, suggesting that the bats had a roost nearby.

The Park also has an observation card (evidently without a specimen) labeled Eumops perotis from Indian Cove Campground “Site 62,” recorded on 23 March 1969. The 'Description' field noted that "Bat was found caught in a catclaw bush. Died when gotten free.” Observer was listed as "Donaldson.” The species was originally listed as Big Free-tailed Bat (Tadarida molossa = Nyctinomops macrotis), but this was scratched out and replaced with "Mastiff Bat Eumops perotis.”

We list the pocketed free-tailed Bat (Nyctinomops femorosaccus) as "Unconfirmed” at Joshua Tree. It occurs at least as close as canyons in the vicinity of Mecca, south of Joshua Tree NP. It is possible that small numbers of pocketed free-tail may occur in the Park, or may occasionally wander up from the south.

The taxon formerly called Merriam's Chipmunk (Neotamias merriami) has been split into two very similar species - Merriam’s chipmunk, and the California or dusky chipmunk ( $N$.

obscurus). Before this split, Merriam's chipmunk was listed as occurring at Joshua Tree, but it is now thought that most or all of the chipmunks within the boundaries of the Park are California chipmunks, which occur in lower-elevation, more arid habitats in this area, in association with singleleaf pinyon pine. However, Merriam's chipmunk (in the new, restricted sense) does occur near Joshua Tree NP in the San Bernardino Mountains, and the habitat relationships between the two species are complex (Best and Granai 1994a, 1994b). Therefore it seems possible that the latter species may also be present in the western area of the Park.

The chisel-toothed Kangaroo Rat (Dipodomys microps) is known only from two specimens collected in the area of Stubbe Spring in the southwest part of Joshua Tree NP, along the Little San Bernardino Mountains. This site is distinctly separate from the nearest other populations of chisel-toothed kangaroo rat (e.g. at Mojave NP). These kangaroo rats have not been seen since the 1940's (Miller and Stebbins 1964). We trapped specifically for this species around Stubbe Spring, and could not locate it.

The California vole (Microtus californicus) formerly occurred in Morongo Valley, just outside Joshua Tree NP on the west. We searched and trapped for this species along Long Canyon in the west part of the Park, but found no sign of it. The wet, marshy habitat at Morongo Valley has been converted, and it is doubtful if the species persists even there.

As at Death Valley, the house mouse has been reported from in and around developed areas just outside of Joshua Tree NP on the north and northwest side. It may also occur within Park boundaries. However, whether this species occurs in a wild state within the Park, and whether it persists presently, are both unknown. 
We include the northern raccoon (Procyon lotor) on the Joshua Tree list as "Unconfirmed," because of expanding urbanization along the western and northern edges of the Park. These may well provide an avenue for this species to eventually show up in the Park.

There are several sight reports of long-tailed weasel (Mustela frenata) at Joshua Tree NP, but we have been unable to find documentation for any of these sightings. Until further evidence is found, we are leaving this species as Unconfirmed.

\section{Lake Mead National Recreation Area}

The long-eared myotis (Myotis evotis) occurs primarily in forested uplands, although it is also sometimes found at lower elevations in semiarid shrub habitats (Manning and Jones 1989). In Arizona, it is recorded from Ponderosa and Spruce - Fir habitats (Hoffmeister 1986). The nearest specimen records to Lake Mead NRA are from the Kaibab Plateau (Hoffmeister 1986) and the mountains of western Clark County, Nevada (Hall 1946). It is possible that this species will be found on the Shivwits Plateau.

The spotted bat (Euderma maculatum) has been recorded from Beaver Dam Creek near Littlefield in extreme northwestern Arizona (Hoffmeister 1986), and is also known from the western Grand Canyon in habitats similar to some areas of Lake Mead NRA (Drost et al. 2000). The species is to be expected at Lake Mead.

Occurrence of the silver-haired bat (Lasionycteris noctivagans) along Las Vegas Wash is noted by Bradley and Niles (1973). Precise location of the record is not known (whether within the boundaries of Lake Mead NRA or not), however, so we do not list the species as documented for Lake Mead. This species appears to have at least a weakly-developed migratory habitat (Kunz 1982), which increases the likelihood that it may turn up at Lake Mead, particularly at higher elevations.

There is a specimen record of the western red bat (Lasiurus blossevillii) from Overton, in eastern Clark County, Nevada (Museum of Vertebrate Zoology). Depending on the precise location where this specimen was collected, it may or may not have been within the present boundaries of Lake Mead NRA (though if it was not within the park boundaries, it was very close). The red bat has also been reported from Las Vegas Wash, but again, it is not clear whether the occurrence was from within the boundaries of the Recreation Area. Given these occurrences very close by, however, and the wide-ranging habits of this species on migration, it is highly likely that the western red bat is an occasional visitor to Lake Mead NRA.

The western small footed myotis (Myotis ciliolabrum) has been recorded from scattered locations around Lake Mead NRA, including east of Lake Mohave (16 mi. NW of Kingman, SE edge of Mineral Park, University of Illinois Museum of Natural History (UIMNH) - cited in Hoffmeister 1986) and on the Shivwits Plateau (Diamond Butte, north of Parashant Canyon - also UIMNH, in Hoffmeister 1986). This bat is likely to be present at Lake Mead, particularly on the Shivwits Plateau. 
The mountain cottontail (Sylvilagus nuttallii) has previously been listed for the Shivwits Plateau area of LAME, based on scattered observations and an older checklist (Baldwin 1944). We have not found any substantial documentation for this occurrence, and the species was not recorded in extensive surveys of the Arizona Strip (including the Shivwits Plateau area) by Hoffmeister and Durham (1971; see also Hoffmeister 1986). Hoffmeister and Durham note that cottontails were relatively scarce during their surveys, however, and seem to leave open the possibility that mountain cottontails might be found in some of the higher areas, as on Mt. Dellenbaugh, where they noted observing a "very wary cottontail" (Hoffmeister and Durham 1971, p. 28). The nearest specimen records for $S$. nuttallii are from the Kaibab Plateau (Hoffmeister 1986).

Schwartz et al. (1978) noted small chipmunks in the vicinity of Mt. Dellenbaugh that they thought were least chipmunks (Neotamias minimus). We do not know of any verification for this claim. The nearest records listed by Hoffmeister (1986) and Hall (1946) are the Kaibab Plateau, Arizona, and the vicinity of Ursine in northern Lincoln County, Nevada. Nonetheless, there is suitable habitat in the Shivwits Plateau area, and this species may actually be present there.

The southern pocket gopher (Thomomys umbrinus) has previously been mistakenly listed for Lake Mead National Recreation Area (Schwartz et al. 1978). This species is restricted to the southern part of southeastern Arizona and extreme southwest New Mexico. Botta’s pocket gopher (T. bottae) is the only pocket gopher known from the Lake Mead area.

The nearest record for the chisel-toothed kangaroo rat (Dipodomys microps) that we can find is from 3 miles west of lower Pigeon Springs in the Grand Wash drainage, approximately $14 \mathrm{~km}$ from the boundary of Lake Mead NRA. A specimen was also collected near the southern base of the Virgin Mountains (Red Cliffs, 17 mi. E of Overton, Clark County, NV, cited in Hall 1946). This is about $16 \mathrm{~km}$ from the nearest boundary of Lake Mead NRA.

Ord's kangaroo rat (D. ordii) occurs near the boundaries of Lake Mead NRA, as at Nixon Springs at the foot of Mount Trumbull. We did not catch this species in our sampling on the Shivwits Plateau, but it is possible that it occurs within Lake Mead NRA boundaries in that area.

The Great Basin pocket mouse (Perognathus parvus) very likely occurs within Lake Mead NRA. There are specimen records quite close to the Shivwits Plateau portion of Lake Mead (Oak Grove, ca. 3 mi. N and 2 mi. W of Mount Dellenbaugh -UIMNH; see Hoffmeister 1986). We did not capture this species in our field sampling on the Shivwits Plateau, however, and as far as we know, there are not yet any definite records from within the boundaries of the Recreation Area.

Hall (1946) lists a record of the hispid cotton rat (Sigmodon hispidus) from along the Colorado River, “ $1 / 2$ mile north of the California - Nevada border” (von Schmidt's meridian post, i.e. the southern tip of Nevada). This location is approximately $25 \mathrm{~km}$ downstream of Davis Dam, and the nearest point of Lake Mead NRA. Also, what was called S. hispidus in Hall's time (i.e. the populations of cotton rats along the Colorado River in the vicinity of the Bill Williams River) has since been separated out as $S$. arizonae, the Arizona cotton rat. The closest occurrence of true $S$. hispidus to Lake Mead is along the lowermost Colorado River, in the vicinity of Yuma. 
A road-killed specimen of the white-backed hog-nosed skunk (Conepatus leuconotus) was found by Huey (1961) 1/2 mi. S of the Temple Bar Junction along U.S. Highway 93. This is less than 3 $\mathrm{km} \mathrm{E}$ of the boundary of Lake Mead NRA in this area. We do not know whether this species is expanding its range, or has simply been present and unnoticed. Given this specimen record, and the presence of suitable habitat in nearby areas within the park boundaries, it is very likely that the hog-nosed skunk occurs at Lake Mead.

Schwartz et al. (1978), citing an unpublished manuscript on the flora and fauna of Clark County, Nevada (Deming 1953), noted it was possible that pronghorn (Antilocapra americana) once occurred in the Gold Butte area of eastern Clark County. Hall (1946) did not include pronghorn as part of the mammal fauna of the state of Nevada, but Hoffmeister (1986) noted that pronghorn were "plentiful at one time on the Arizona Strip," including Tuweep and Antelope Valley, northeast of Mount Trumbull. Other place names on the Arizona Strip such as Antelope Knoll and Antelope Spring suggest that pronghorn were once common in the area. Hence the species may well have once roamed some of the lands now included within Lake Mead NRA, Pronghorn were reintroduced onto the Arizona Strip in 1961, and now number in the low hundreds in areas north of Lake Mead boundaries on the Shivwits Plateau Bureau of Land Management / Arizona Strip website, http://www.blm.gov/az/wildlife/pronghorn.htm).

Schwartz et al. (1978) also noted a report of a lone male goat (Capra hircus), presumably feral, near Burro Bay on the north side of Lake Mead, some time in 1963. We know of no subsequent reports of goats within Lake Mead NRA.

\section{Manzanar National Historic Site}

The Museum of Vertebrate Zoology has specimens of the water shrew (Sorex palustris) from 4 miles West of Lone Pine, along Lone Pine Creek (south of Manzanar). Although unlikely, it is possible that the water shrew may occur at Manzanar.

We were unsuccessful in either mist-netting or surveying with Anabat at Manzanar. The bats listed as probable or unconfirmed for Manzanar are species that are known to occur at low elevations in the Owens Valley. Species that are most likely to be found at Manzanar include the big brown bat (Eptesicus fuscus), California myotis (Myotis californicus), Yuma myotis (Myotis yumanensis), and Brazilian free-tailed bat (Tadarida brasiliensis). The hoary bat (Lasiurus cinereus) and possibly the western red bat (L. blossevillii) may be encountered during migration.

The house mouse is widespread in the Owens Valley, including the vicinity of both Independence and Lone Pine (specimens at Los Angeles County Museum of Natural History, and Museum of Vertebrate Zoology). It is likely to occur in and around human settlements, and areas with water, as at Manzanar.

The Long-tailed Weasel (Mustela frenata) has been recorded along the Owens River north of Independence (Museum of Vertebrate Zoology specimen), and so might be found at and around Manzanar. 
Pronghorn were once widespread in the Owens Valley, but were extirpated in the early 1900's (Putman and Smith 1995). They presumably once ranged over the area that is now Manzanar National Historic Site.

Mule deer (Odocoileus hemionus) are common in the Owens Valley. We did not record any within the boundaries of Manzanar during our fieldwork there, but they presumably are present at least seasonally.

\section{Mojave National Preserve}

Mojave National Preserve is within the known range of California Leaf-nosed Bat (Macrotus californicus), but we are not aware of any confirmed records from inside the boundaries of the Preserve. We did not encounter the species in our field surveys, and it has not been recorded in other surveys that have been reported (including surveys specifically for bats, e.g. Ecological Ventures California 2001). Macrotus has been collected from the eastern edge of San Bernardino County, near Mojave NP (San Bernardino County, 2 mi N Colorado River, 0.125 mi W Nevada boundary - MVZ; this location description is somewhat ambiguous because of its reference to "north" of the Colorado River, but it is clearly easternmost San Bernardino County, and the location in relation to the Colorado River indicates it is not within the boundary of Mojave NP). This species seems quite likely to occur at Mojave NP, at least on an occasional basis.

The spotted bat (Euderma maculatum) has been found in widely scattered locations in California surrounding Mojave NP (see, e.g. Pierson and Rainey 1998) and in adjacent areas of Nevada and Arizona. It is likely that this species is at least a rare visitor to Mojave NP.

The western red bat is occasionally found in the desert during its spring and fall migration (e.g. the specimens from Death Valley and from the Overton Arm of Lake Mead). Similarly, if the species occurs at Mojave NP, it would show up as a migrant. An extensive wooded riparian strip like the one at Piute Springs would be an attractive stopover area for this species on migration.

We made two different trips to areas of white fir on the upper reaches of Clark Mountain looking for the Bushy-tailed Woodrat (Neotoma cinerea). We did not find this species in our trapping of the area, but further survey would be worthwhile.

There are old records of the gray wolf (Canis lupus) from what is now Mojave NP, including a skull that was collected in the Providence Mountains (located at MVZ). The wolf was probably a rare resident or transient at Mojave, and of course is now long gone.

Mule deer were introduced to the New York Mountains in the 1940's and spread to other ranges. We do not know of strictly native populations within Mojave National Preserve. The introduction of mule deer may have led to immigration of mountain lions into the mountain ranges of the preserve (or at least a substantial increase in numbers of lions). In their survey of the Providence Mountains in the 1940’s, Johnson et al. (1948) found neither deer nor lions. By the time Stein and Warrick (1979) surveyed the Granite Mountains, both deer and mountain lions were present in that area. 


\section{Discussion}

\section{Museum Records}

We reviewed specimen records from 11 different museums, located mainly in the southwestern United States, but also including the U.S. National Museum in Washington, D.C., and the University of Illinois Museum of Natural History (which has significant holdings from Arizona and the Lake Mead area). We searched records at some other museums (e.g. the Monte L. Bean Life Sciences Museum at Brigham Young University), but did not find pertinent records at these other sites. All of the museums contributed important records, but some clearly stood out as being particularly valuable. The National Park Service museum collections at Death Valley and Joshua Tree were important because almost all of their specimens represent those parks. Among the major museums, the Museum of Vertebrate Zoology at Berkeley (MVZ) stands out because of the large numbers of specimen records it has for the parks (we reviewed over 5,200). This is especially true for Death Valley, as MVZ has holdings from several intensive studies that were conducted at sites within Death Valley NP. Particularly for the more southerly parks, the Natural History Museum of Los Angeles County (LACM) was important, with approximately 850 specimens from the area of NPS lands. In addition to reviewing records from individual museums, we also consulted the statewide compilations prepared by Hoffmeister (1986) for Arizona, and Hall (1946) for Nevada. These sources were particularly valuable in evaluating mammal species status at Lake Mead NRA.

The value of the extensive holdings of the Museum of Vertebrate Zoology (and, by extension, of other regional museum collections) to current knowledge and management of the Mojave parks, is not a coincidence. When the work of the Museum of Vertebrate Zoology was just beginning, its first director, Dr. Joseph Grinnell, stated “...the greatest purpose of our museum... is that the student of the future will have access to the original record of faunal conditions in California and the west, where-ever we now work" (Grinnell, 1910, quoted on the MVZ website, http://mvz.berkeley.edu/Grinnell/index.html). Grinnell might well have added "the land manager of the future” as well, as he clearly foresaw developing threats to native plant and animal diversity and native habitats in the western United States.

During our review of museum and literature records, we frequently had to make decisions about whether the information represented valid records for the Mojave parks. For older information, especially, location data for specimens is frequently imprecise, or just refers to a broad region. In many cases, we encountered approximate locations that were near the boundaries of one of the Mojave park units, or locations that referred to obscure historic locations. We were conservative in our interpretation of these locations; if a location was near the boundary of one of the park areas, but we could not be sure it was within, we left the status of that record as "probable" instead of "documented." Such records were retained in the museum database, with all available detail for the record. In the database, these records are noted as "Near" the park (e.g. "Near LAME"), with an estimated distance in some cases. We considered it important to retain these records, as they are still potentially important in understanding both the current and historic status of mammal species at the Mojave parks. 


\section{Sampling Effort}

This project was originally proposed for two sampling seasons. However, it quickly became apparent in 2002 that the extended drought of the time was having serious impacts on our trapping success. The total annual precipitation in 2002 was $25 \%$ or less of normal at all of the Mojave parks (data from NOAA 2006). For this reason, we scaled back sampling to save field time and funding for better conditions. The 2003 season was near normal or greater, and 2004 had higher rainfall totals for all areas (Figure 1). Hence, we carried field sampling over into 2004, and completed small mammal live trapping with targeted efforts for particular species of interest in that year. The higher rainfall in 2003 and 2004 provided an evident boost in small mammal numbers This was seen in increased trap success in late spring and summer at Death Valley and Joshua Tree (Table 5). Trap success reached a high of 80\% in June 2004 at Death Valley. Evident effects of the past winter's rain were also seen in small mammal recruitment; this was the first year in which we captured significant numbers of young individuals.

Over the three years of field sampling, we covered broad areas of each of the Mojave Network Parks. This included sites from Hunter Mountain in the north to Saratoga Springs in the south at Death Valley NP, Long Canyon to the Eagle Mountain area at Joshua Tree, areas on the Shivwits Plateau to the Newberry Mountains at Lake Mead, and from the Devils Playground area to Piute Springs at Mojave National Preserve. Given its small size, Manzanar was covered rather thoroughly. Table 3 summarizes the overall schedule of field sampling, and Table 4 lists cumulative totals of small mammal captures for each Park unit. Complete sampling and capture data are contained in the database files provided separately.

\section{Field Sampling}

The variety and numbers of small mammals that we trapped (Tables 5 and 6 ) is more a reflection of the specific 'priority study areas' and habitats that we surveyed, rather than an overall indication of diversity and abundance over the entire area of any of the Mojave parks (the one possible exception to this is Manzanar, which is small enough that our trapping results may provide a fair overall picture of mammal variety and numbers). Notable in this respect are the high numbers of white-footed mice (Peromyscus spp.) at some of the parks. Numbers of these species were quite high in areas where we focused sampling around springs. Numbers of the heteromyid rodents (pocket mice, kangaroo rats) were comparatively low in these dense habitats, compared to surrounding arid shrublands. For example, at Death Valley, where much of our sampling was at springs, the three most numerous captures were canyon mouse ( $P$. crinitus), deer mouse ( $P$. maniculatus), and cactus mouse (P. eremicus). In contrast, at Joshua Tree, where most sampling was in various desert scrub habitats, heteromyids dominated, led by Merriam's kangaroo rat (Dipodomys merriami) and little pocket mouse (Perognathus longimembris).

Noteworthy species at the other park units included spiny pocket mouse (Chaetodipus spinatus) at Lake Mead, at or near the northern extent of the range for this species, and the Arizona woodrat (Neotoma devia). The latter is a "new" species for Lake Mead, by virtue of the taxonomic separation of this form from the desert woodrat ( N. lepida; the Arizona woodrat occurs south and east of the Colorado River, while the desert woodrat occurs on the other side of the river, in the Nevada and California desert). We also found house mice (Mus musculus) in wildland habitats at Lake Mead, at Blue Point and Rogers Springs (Figure 2). Previously, this 
introduced species was thought to be restricted to areas around human habitations, as at Boulder City and areas along Las Vegas Wash (Schwartz et al. 1978).

At Manzanar, the California vole (Microtus californicus) is an important species for that area (Figure 3). The subspecies in this area is the Owens Valley vole (M. c. vallicola), which is a California Special Concern species (State of California “Special Animals” list, available at http://www.dfg.ca.gov/bdb/pdfs/spanimals.pdf). At Mojave National Preserve, the spiny pocket mouse is at or near the northern edge of its range. We caught spiny pocket mice in the Piute Springs area near the eastern edge of the Preserve (Figure 4).

Although field sampling for this project was not designed specifically to assess other aspects of small mammal ecology such as population size and habitat associations, the data do add to overall knowledge of distribution of the different species, and provide general indications of relative abundance and habitat occurrence. In particular, our sampling adds to distribution and abundance data for areas of the different park units which had previously been sampled little or not at all. These areas include the Last Chance Range and Darwin Plateau / Argus Range (northwest border of park) at Death Valley NP, the Eagle and Coxcomb Mountains, and the Long Canyon / Quail Springs / Smith Water Canyon area at Joshua Tree NP, the Newberry Mountains, Black Mountains, and Shivwits Plateau area at Lake Mead NRA, and the Piute Range, Providence Mountains, and Clark Mountains at Mojave NP. As previously noted, there has been no mammal sampling at Manzanar, so all of the areas surveyed there are "new."

\section{Species Lists}

The species lists for each of the Mojave Network park areas (Tables 7 -11) are intended to be as complete, up-to-date, and consistent as possible. Both in this report and in the NPSpecies database, we have documented evidence and, where necessary, our interpretations for including mammal species on the list for each area. Literature sources, where available, are cited in this report and in NPSpecies. All of the museum specimen records pertaining to species occurrence in each park area are included in a companion database. Mammal species totals that we consider to be adequately documented for each area are: Death Valley - 59 species; Joshua Tree National Park - 50 species; Lake Mead National Recreation Area - 59 species; Manzanar National Historic Site - 19 species (very incomplete); and Mojave National Preserve - 50 species.

There is room for differences of opinion in accepting some species as adequately documented or not (i.e. species listed as "Probably Present" or "Unconfirmed"). We have tried to be conservative throughout, not listing species as definitely present unless there were museum specimen records from within the boundaries of an area, literature references that clearly identified a species within an area, or well-documented, verifiable capture or sighting records for a species. There have been previous, comprehensive listings of mammal species for Joshua Tree NP (De Lisle 2002) and Lake Mead NRA (Schwartz et al. 1978). Compared to De Lisle's list for Joshua Tree, our list has only minor differences in interpretation (e.g. as to confirmed presence within the Park), and some updates to species names. In the compilation by Schwartz et al., it is not clear for some species whether there were documented occurrences of a particular species within the boundaries of the Recreation Area, or just nearby. For example, Schwartz et al. (1978) include the Arizona cotton rat (Sigmodon arizonae, called S. hispidus by Schwartz et al.) on their list. However, the nearest record of this species to Lake Mead NRA is approximately 25 $\mathrm{km}$ south of the southern boundary of Lake Mead, and this population may no longer be extant 
(Bradley 1986). As with De Lisle, there are minor differences of interpretation for some species, and updates to taxonomy and nomenclature for the Lake Mead list.

\section{Completeness of inventory}

The difficulty of conclusively determining the presence of all of the species of any taxonomic group (particularly when secretive, difficult-to-sample species are involved) is well-illustrated by long-term studies of the Savannah River Site in South Carolina (Gibbons et al. 1997). After 45 years of extensive and intensive, year after year study of the amphibians and reptiles at this 803 $\mathrm{km}^{2}$ site, researchers at the site were still finding occasional new species (the species found in the $45^{\text {th }}$ year was the large, albeit retiring and secretive, gopher tortoise). Particularly when vagile species are involved, there is the additional complication that species may come and go in the area over long periods of sampling. A good example of this among mammals, of course, is presented by the bats.

Our assessment of inventory completeness for the Mojave Network parks is based on the synthesis of all available data - recent field sampling, museum specimen data, and specific literature pertaining to the Mojave park units. At the outset of this project, we prepared a hypothetical species list, as a guide for directing the sampling effort, and also as a comparison against which to judge the inventory list. A significant problem with this approach, however, is that any hypothetical list is based on subjective judgments, and a more or less extensive hypothetical list can make the inventory list look either worse or better. When judged against a "conservative" hypothetical list (one that only contains species that are very likely to be present in the area), the inventory list will look very good -i.e. it will score a high percentage for "completeness." In contrast, a very "liberal” hypothetical list (one containing more species that could conceivably show up in the area, but are actually very unlikely) will make the inventory list look comparatively "bad." In either case, of course, neither score is demonstrably correct, because the hypothetical list was simply a best guess to begin with.

To try to better account for this uncertainty in the hypothetical lists, we used a weighted calculation of the species on the hypothetical list, similar to that used by Persons and Nowak (2005). Because there were species that were positively documented from the Mojave Network parks, we gave these species a weight of 1 . Other, undocumented species received a fractional weight, depending on our judgment of their probability of occurrence in the area (ranging from high-probability species $=0.83$, to low-probability species $=0.17$ ). Our assessment of inventory completeness for the different Mojave Network parks ranged from 89\% for Mojave National Preserve and Joshua Tree National Park on the high side, to 52\% for Manzanar National Historic Site on the low side. The low score for Manzanar is due in large part to the lack of previous work there; we found no museum specimens and no literature references that provided specific data on mammal species occurrence for Manzanar. The mammal inventory completeness for Manzanar also suffered, unfortunately, from our failure to collect any useful information on bats. We did not capture any bats in the areas of the site that we used mist nets, and an equipment failure prevented our collecting data with Anabat on the only Manzanar trip that we had that equipment available. We plan to work with the staff of Manzanar to conduct supplemental Anabat surveys there, to help correct this obvious deficiency.

For all of the Mojave parks, we almost certainly erred toward including too many species on the hypothetical lists, so that the actual inventory completeness of each area is probably higher than 
what we have calculated. We feel that this "conservative" approach of including more species than are actually likely to occur, is preferable to using a restricted hypothetical species list, and possibly leaving off mammal species that we might then overlook. The hypothetical species lists remain a good "watch" list for other mammal species that might be found in the parks - even if only on a rare and occasional basis.

Besides questions on how best to calculate completeness of inventory, and how conservative or broad a hypothetical species list should be, there are other issues with trying to reduce the concept of inventory completeness to a single number. In particular, among the bats at least, there are some species that occur within the monuments on an occasional or irregular basis. This is particularly true for relatively small areas such as Manzanar, but also applies to marginal or occasional occurrence of species in larger areas. The inclusion of hoary bat for any of the Mojave Network parks is based on very few records (evidently just a single, well-documented record for Lake Mead). The hoary bat is a migratory species, and it is unlikely that the species is resident at any of the Mojave parks, other than as spring and fall migrants. The species is only expected on a seasonal basis, then, but it is possible that hoary bats pass through some or all of the areas on an annual basis. There are obvious problems with surveying for a species like this, or even for assigning an accurate status for it.

There are similar situations even among non-flying species. Our inclusion of the spiny pocket mouse (Chaetodipus spinatus) on the Lake Mead list is based on a single trap capture in Bridge Canyon in the Newberry Mountains in the southern part of Lake Mead lands (there is also a single record from Willow Spring (= Granite Springs) along Sacatone Wash in the same area, that is just inside the Lake Mead boundary; Ryser 1964). A species like this, recorded by only one or two captures in a small area near the margin of one of the parks, obviously would have been very easy to miss.

\section{Management Implications}

Inventories of large areas are rarely fully "complete,” particularly considering the difficulty of detecting rare, cryptic, marginally-occurring species, coupled with changes in occurrence and numbers of some species (as discussed previously). However, the combination of careful review of museum and literature information, together with extensive, targeted field sampling over multiple years covering a range of environmental conditions, provides a sound inventory baseline that should satisfy most requirements of natural resource managers at the Mojave Network parks.

From a management standpoint, most of the species listed as "Probable" or "Unconfirmed" for the Mojave Network parks (Tables 7 -11) are common, widely distributed species that are simply near the edge of their geographic or ecological / habitat range. As such, most of these species are not likely to be high priorities for management. There are some Probable / Unconfirmed species, however, whose documented presence in an area would be of greater conservation and management interest, and these species may merit further targeted survey work, as discussed below. 
Park staff, visiting researchers, and visitors to the all of these areas will almost certainly be able to add to the mammal lists presented here. It is likely, too, that in-house materials at the different Network park areas, such as unpublished reports and perhaps even well-documented "observation cards" may hold additional information (we were able to review some of this material, but by no means all). Interested persons should be on the lookout for those species listed as "Probably Present" This is particularly true of the species that are at least partly diurnal, such as long-tailed weasel and at Joshua Tree, and ground squirrels and chipmunks at several of the areas.

\section{Additional Survey}

Shrews are the most problematic group among the nocturnal small mammals. They are sparsely distributed, may be rather specific in their habitat requirements, and are generally difficult to sample for. Our field sampling for this project added little to our knowledge of the presence or absence of potentially-occurring shrew species. This is one area in particular where additional surveys targeted specifically for potentially-occurring shrew species is likely to yield much better understanding - both in terms of presence or absence of species, and of habitat occurrence.

Compared to most other native mammals, there is also a comparatively limited base of knowledge for bats. In particular, less is known of habitat affinities and the overall distribution of bat species in this area, to guide targeted survey efforts. Additional work on bats should focus on broader general surveys to help overcome this limitation, as well as targeted surveys at specific sites of interest. A very useful and cost-effective supplement to bat surveys would be the use of remotely recording ultrasonic bat detectors, which may be set out at various sites (e.g. mine entrances, or other potential roost sites), left to record for one or more evenings, then retrieved and downloaded. These units are relatively new and record calls to compact flash cards similar to those used in many digital cameras. Having a number of these units can multiply effective survey effort considerably, and the units can also be employed for repeat monitoring of mine sites or other areas of particular concern to the parks. Use of the units does require either staff expertise in identification of bat calls, or collaborators who can assist with species identification.

Our fieldwork for this study included some diurnal surveys in various areas for species such as ground squirrels and chipmunks. For Death Valley NP in particular, further surveys for this group may be of substantial interest for potential further additions to the Park species list (at least one chipmunk species), because of the occurrence of rare, limited-distribution species in the Park (Mojave ground squirrel, Spermophilus mohavensis), and because some of these species are represented by isolated populations at the edge of their range. Such marginal species are most susceptible to long-term changes in their habitat, and repeat surveys could provide valuable data for evaluation of long-term trends.

Other marginal or isolated populations within the Mojave Network parks may also merit further study and monitoring. A disjunct population of the chisel-toothed kangaroo rat (Dipodomys microps) in Joshua Tree NP appears to have been extirpated. We and others have specifically searched the area where this kangaroo rat was previously found (Stubbe Spring and vicinity) and have been unable to locate it. Isolated and edge-of-range species like this kangaroo rat population may be expected to be the first populations to disappear with regional changes in 
climate and habitat. Further investigation of chisel-toothed kangaroo rat at Joshua Tree NP might include possible habitat change in the area.

\section{Species of concern}

Mammal species of special interest at all of the Mojave Network park areas include some of the bat species, in particular. These include some widely-distributed species found at most or all of the parks (e.g. Townsend's big-eared bat) and other rare or marginal species documented at only one or two areas (e.g. the California leaf-nosed bat and the spotted bat). Species of most interest and concern are probably those that resident populations, especially in caves and mines (again including the California leaf-nosed bat, Townsend's big-eared bat and several other species). Resource staff at the Mojave Network parks are quite aware of conservation concerns for resident bat species, and have invested considerable time and energy into management efforts for these species (e.g. Burghardt 2004).

Other mammal species that may be of particular management interest at some of the Mojave Network parks include:

- For Death Valley National Park: the Mojave ground squirrel, a restricted, special concern species whose range edges into the southwestern portion of the Park; and the pale kangaroo mouse (Microdipodops pallidus), a restricted-range species that may occur marginally in the northernmost part of the Park (but not yet confirmed there).

- For Joshua Tree National Park: the chisel-toothed kangaroo rat, discussed above.

- For Lake Mead National Recreation Area: the spiny pocket mouse, which reaches the northern edge of its range in the southern part of Lake Mead, in the Newberry Mountains area; and the house mouse, an introduced species which has recently been confirmed around some of the springs in the northern part of Lake Mead.

- For Manzanar National Historic Site: the Owens Valley subspecies of the California vole, which is a California "Special Concern Species."

- For Mojave National Preserve: the spiny pocket mouse, which (as for Lake Mead), reaches the northern extent of its range in the eastern part of the Preserve.

\section{Long-term Monitoring}

In its national inventory and monitoring program, the National Park Service sees natural resources monitoring as an important follow-on to inventory studies (National Park Service 1992). The "vital signs" approach adopted by the Park Service recognizes that long-term monitoring at the scale of park lands is a complex undertaking that necessarily involves a broad range of indicators of the health of natural systems. The Mojave Network is actively planning and developing its monitoring program in network parks (overview in http://science.nature. nps.gov/im/units/mojn/monitor/vs_main.cfm). Among a broad range of measures of the physical and biological environment, the Mojave Network included a number of plant and animal communities and species as monitoring priorities. Among mammals, these included special status species that are rare or otherwise of immediate management interest (e.g. bats, mule deer, bighorn sheep), as well as species groups that reflect the status and trends of important natural 
communities (e.g. small mammals) (notes from NPS Mojave Network Vital Signs workshop, May 25-27, 2004; see also http://science.nature.nps.gov/im/units/MOJN/monitor/

vs_biological.cfm).

Important advantages of monitoring mammals include the specific management concern for some species (e.g. bats, which were listed as species of concern by all network parks), the availability of methods for measuring and interpreting mammal populations and communities (e.g. Baker et al. 2003), and a relatively good understanding of how mammal species and communities relate to aspects of their environment. Some mammals are closely tied to habitat conditions and their populations may respond markedly to changes in habitat conditions. Markrecapture methods provide the ability to accurately estimate densities of small mammals (identified by network parks as a potential monitoring target), and there are a variety of methods for assessing and quantifying bat communities and populations (e.g. O'Shea et al. 2003). 


\section{Acknowledgments}

This project owes much to the field staff who carried out most of the sampling and data collection at the Mojave Network parks. Their hard work, care, and diligence in field work and data handling provided the foundation of what is reported here. Thanks go to Lisa Gelczis, Mary Ellen Prince, and Jenohn Wrieden (2002), Amanda Matthews and Kristen Pearson (2003), and Garrett Holway, and Wendy and David Tidhar (2004). Elena Salpas and Hertha Woody (an intern from the organization 'Native Americans for Community Action') accomplished much of the painstaking data compilation, editing, and review. The excellent results of the bat sampling are primarily due to Chris Corben and his great knowledge and expertise with Anabat. We also thank Park staff for their assistance and advice on accessing different areas of the two monuments, and for sharing their knowledge of the monuments. Special thanks are due Linda Greene, Linda Manning, and Dana York (Death Valley National Park), Hank McCutchen, Harold De Lisle, Amy Fesnock, and Jane Rodgers (Joshua Tree National Park), Kent Turner, Ross Haley, and Libby Powell (Lake Mead National Recreation Area), Frank Hays (Manzanar National Historic Site), and Larry Whalon, Debra Hughson, and Kitty Jensen (Mojave National Preserve). Darla Sidles (Parashant National Monument) was also instrumental in assisting with access to the remote Shivwits Plateau area of Lake Mead NRA and the adjacent Parashant NM. Jim Andre (University of California Granite Mountains Reserve) graciously aided us in our sampling of the Granite Mountains area of Mojave NP.

Review of local museum holdings added greatly to this project. For assistance with access to their holdings, we thank Jens Vindum (California Academy of Science), Blair Davenport (Death Valley National Park Museum), Melanie Spoo (Joshua Tree National Park Museum), John Heyning (Los Angeles County Museum of Natural History), Janet Gillette at the Museum of Northern Arizona, Tad Theimer, (Northern Arizona University), and Phil Unitt (San Diego County Natural History Museum). Finally, we thank the Inventory and Monitoring Office staff of the NPS / Mojave Network - especially Kristina Heister and Craig Palmer - for their help with the administration, oversight, and aspects of coordination of this project.

\section{Literature Cited}

American Society of Mammalogists. 1987. Acceptable methods in mammalogy. J. Mammal. 68(4):supplement.

Baker, R. J., L. C. Bradley, R. D. Bradley, J. W. Dragoo, M. D. Engstrom, R. S. Hoffmann, C. A. Jones, F. Reid, D. W. Rice, and C. Jones. 2003. Revised Checklist of North American Mammals North of Mexico, 2003. Occasional Papers, Museum of Texas Tech University number 229.

Baldwin, G. C. 1944. A check-list of the mammals of the Boulder Dam Recreational Area. National Park Service mimeo. Boulder City, NV.

Baldwin, B., S. Boyd, B. Ertter, R. Patterson, T. Rosatti, and D. Wilken. 2002. The Jepson desert manual. University of California Press, Berkeley.

Best, T. L., and N. J. Granai. 1994a. Tamias merriami. Mammalian Species no. 476. American Society of Mammalogists. 
Best, T. L., and N. J. Granai. 1994b. Tamias obscurus. Mammalian Species no. 472. American Society of Mammalogists.

Bradley, W. G. 1966. The status of the cotton rat in Nevada. J. Mammal. 47:349-350.

Bradley, W. G. and J. E. Deacon. 1971. The ecology of small mammals at Saratoga Springs, Death Valley National Monument, California. Journal of the Arizona Academy of Science 6: 206-215.

Bradley, W. G, and W. E. Niles. 1973. Study of the impact on the ecology of Las Vegas Wash under alternative actions in water quality management. Final report to Las Vegas Valley Water District.

Brown, P. E. 1993. Bat survey of mountain ranges adjacent to Pinto Basin, Joshua Tree National Monument, California. Report to Joshua Tree National Monument, August 1993.

Burghardt, J. 2004. Securing bat habitat in mines and caves at six national park areas. Natural Resource Year in Review - 2004. National Park Service (on the web at: http://www2.nature.nps.gov/ YearInReview/yir2004/04_H.html).

De Lisle, H. F. 2002. Annotated checklist of the mammals of Joshua Tree National Park. Unpublished report., $17 \mathrm{pp}$.

Deming, O. V. 1953. The flora and fauna of Clark County, Nevada. Unpublished manuscript.

Drost, C. A., J. Petterson, and E. Leslie. 2000. Survey of bats along the Colorado River through Grand Canyon National Park. Report to Arizona Game and Fish Department, Heritage Grant no. I96031

Ecological Ventures California. 2001. Acoustical and visual chiropteran surveys for the Evening Star Mine, Mojave National Preserve, Ivanpah Mountains, San Bernardino County, California.

Fenton, M. B., D. C. Tennant, and J. Wyszecki. 1987. Using echolocation calls to measure the distribution of bats: the case of Euderma maculatum. J. Mamm. 68:142-144.

Fenton, M. B. 1988. Detecting, recording, and analyzing vocalizations of bats. pp. 91- 104 in: T. H. Kunz (ed.), Ecological and behavioral methods for the study of bats. Smithsonian Institution Press, Washington, DC.

Gannon, W.L., R.S. Sikes, and the Animal Care and Use Committee of the American Society of Mammalogists. 2007. Guidelines of the American Society of Mammalogists for the use of wild mammals in research. Journal of Mammalogy, 88:809-823.

Gibbons, J. W., V. J. Burke, J. E. Lovich, et al. 1997. Perceptions of species abundance, distribution, and diversity: lessons from four decades of sampling on a government-managed reserve. Environmental Management 21: 259-268.

Glue, D. E. 1970. Avian predator pellet analyses and the mammologist. Mammal Review 1:53-62.

Grinnell, J. 1937. Mammals of Death Valley. California Academy of Sciences. 23(9):115-169.

Halfpenny, James. 1986. A field guide to mammal tracking in North America. Johnson Books, Boulder.

Hall, E.R. 1946. Mammals of Nevada. University of Nevada Press. 710 pp.

Hall, E. R. 1979. Mammals of North America. Vol.1, 2nd Ed. Wiley, New York.

Hayes, J. P., and P. Hounihan. 1994. Field use of the Anabat II bat-detector system to monitor bat activity. Bat Research News 35: 1-3.

Hoffmeister, Donald F. 1986. Mammals of Arizona. University of Arizona Press.

Hoffmeister, D. F., and F. E. Durham. 1971. Mammals of the Arizona Strip including Grand Canyon National Monument. Northern Arizona Society of Science and Art Technical Series no. 11, Flagstaff, Arizona. 
Holloway, G. L., and R. M. R. Barclay. 2001. Myotis ciliolabrum. Mammalian Species no. 670. American Society of Mammalogists.

Hoofer, S.R., R.A. Van Den Bussche, and I. Horacek. 2006. Generic status of the American pipistrelles (Vespertilionidae) with description of a new genus. Journal of Mammalogy 87:981-992.

Huey, L. M. 1961. Further northern extension of the Hog-nosed skunk. Journal of Mammalogy. 42:421.

Jameson, E. W., Jr., and H. J. Peeters. 2004. Mammals of California. University of California Press, Berkeley, CA.

Johnson, D.H., M.D. Bryant, and A.H. Miller. 1948. Vertebrate animals of the Providence Mountain area of California. University of California Publications in Zoology 48:221-375.

Jones, C., W. J. McShea, M. J. Conroy, and T. H. Kunz. 1996. Capturing mammals. Pp. 115-155 in: D. E. Wilson, F. C. Cole, J. D. Nichols, R. Rudran, and M. S. Foster (eds.), Measuring and monitoring biological diversity: standard methods for mammals. Smithsonian Press, Washington, D.C.

Kingsley, K.J. 1981. Mammals of the Grapevine Mountains, Death Valley National Monument. National Park Service / Univ. Of Nevada-Las Vegas Contribution No. CPSU/UNLV No. 018/05. 190 pp.

Kunz, T. H. 1982. Lasionycteris noctivagans. Mammalian Species no. 172. American Society of Mammalogists.

Lake Mead National Recreation Area. 2001. Strategic Plan, 2001 - 2005. Available at http://www.nps.gov/lame/parkmgmt/upload/ACFB12.doc

Manning, R. W., and J. K. Jones, Jr. 1989. Myotis evotis. Mammalian Species no. 329. American Society of Mammalogists.

Merriam, C.H. 1893. The Death Valley Expedition, Part II. North American Fauna No. 7: 1-393.

Miller, Alden H. 1946. Vertebrate inhabitants of the pinyon association in the Death Valley region. Ecology. 27(1) 54-60.

Miller, A.H., and R.C. Stebbins. 1964. The lives of desert animals in Joshua Tree National Monument. UC Press, 452 pp.

Murie, Olaus J. 1974. A field guide to animal tracks. Houghton Mifflin Co., Boston.

National Park Service. 1992. NPS-75: Natural Resources Inventory and Monitoring Guidelines. U.S. Dept. of Interior, National Park Service, Washington, D.C.

National Park Service. 1995. General Management Plan for Joshua Tree National Park. U.S. Dept. of Interior, National Park Service, Washington, D.C.

National Park Service. 1999. Guidelines for biological inventories. Inventory and Monitoring Program, National Park Service, Washington, D.C.

National Park Service. 2000. Resource Management Plan for Lake Mead National Recreation Area. Lake Mead National Recreation Area, National Park Service, Washington, D.C.

National Park Service. 2002a. General Management Plan for Death Valley National Park. U.S. Dept. of Interior, National Park Service, Washington, D.C.

National Park Service. 2002b. Mojave National Preserve General Management Plan. U.S. Dept. of Interior, National Park Service, Washington, D.C.

NOAA. 2006. Climatography of the United States. Available on the web at: www.ncdc.noaa.gov/oa/climate/normals/usnormals.html. 
O’Shea, T. J., M. A. Bogan, and L. E. Ellison. 2003. Monitoring trends in bat populations of the United States and territories: status of the science and recommendations for the future. Wildlife Society Bulletin 31:16-29.

Person, T. B., and E. M. Nowak. 2005. Inventory of amphibians and reptiles in southern Colorado Plateau National Parks. Final report to National Park Service, Southern Colorado Plateau Network, February 2005.

Pierson, E. D. and W. E. Rainey. 1998. Distribution of the spotted bat, Euderma maculatum in California. Journal of Mammalogy. 79 (4) 1296-1305.

Putman, J., and G. Smith. 1995. Deepest valley; guide to Owens Valley. Genny Smith Books, Mammoth Lakes, California.

Rainey, D. G. 1965. The distribution of the amphibians, reptiles, and mammals of Joshua Tree National Monument. Report to Joshua Tree National Monument.

Reid, F. A. 2006. A field guide to mammals of North America, north of Mexico. Houghton Mifflin Co., Boston and New York.

Ryser, F. A. 1964. Spiny pocket mouse in Nevada. J. Mammal. 45: 301-302.

Sakai, W.H. and N.D. Hogg. 1999. Animal inventories in Joshua Tree National Park, with special emphasis on sensitive species. Unpublished report, 164 pp.

Schwartz, J., G. T. Austin, and C. L. Douglas. 1978. Amphibians, reptiles and mammals of the Lake Mead National Recreation Area. LAME Technical Report \#2, National Park Service, University of Nevada, Las Vegas.

Stein, B. A., and S. F. Warrick. 1979. Granite Mountains resource survey: natural and cultural values of the Granite Mountains, Eastern Mojave Desert, California. Environmental Field Program Publication No. 1, University of California, Santa Cruz, Santa Cruz, California, USA. 363 pp.

Stohlgren, T. J., and J. F. Quinn., 1992. An assessment of biotic inventories in western U. S. National Parks. Nat. Areas J. 12(3): 145-154.

Suttkus, R. D., G. H. Clemmer, and C. Jones. 1978. Mammals of the riparian region of the Colorado River in the Grand Canyon area of Arizona. Occasional Papers, Tulane University Museum of Natural History no. 2, 23 pp.

Thomas, D. W., and S. D. West. 1989. Sampling methods for bats. Gen. Tech. Rep. PNW-GTR-243. Portland, OR: USDA Forest Service, Pacific Northwest Research Station, 20 pp.

Wemmer, C., T. H. Kunz, G. Lundie-Jenkins, and W. J. McShea. 1996. Mammalian sign. Pp. 157-176 in: D. E. Wilson, F. C. Cole, J. D. Nichols, R. Rudran, and M. S. Foster (eds.), Measuring and monitoring biological diversity: standard methods for mammals. Smithsonian Press, Washington, D.C.

Wilson, D. E., F. R. Cole, J. D. Nichols, R. Rudran, and M. S. Foster. 1996. Measuring and monitoring biological diversity: standard methods for mammals. Smithsonian Institution Press, Washington. 


\section{Tables}

Table 1. Priority sampling locations for Mojave Network Park units. Areas were identified by staff at each park unit as areas of particular concern, or as areas that were poorly known.

\section{Death Valley National Park}

Greenwater Range and Greenwater Valley. Land is newly acquired with little available information; represents prime desert tortoise habitat; representative example of the southern Mojave ecosystem; underlain by volcanic rock.

Owlshead Mountains. Land is newly acquired with little available information; only place in park the smoke tree occurs.

Inyo Range. Small piece of land near the Saline Valley that supports a pinyon-juniper community the most diverse community in the park.

Ibex Hills. Land is newly acquired with little available information.

Argus Range / Darwin Plateau. Historic records (1891) of several rare plants undocumented elsewhere in the park and one observation of the Mojave ground squirrel (state listed threatened) near area; underlain by volcanic rock; threatened by plans to build a mine near park boundary and increased water withdrawal from Darwin Falls.

Springs (Cottonwood and Panamint Mountains). Spring locations at DEVA represent islands of biodiversity in an otherwise unwatered landscape. Springs in the Cottonwood and Panamint Mountains have little information available on flora and fauna.

\section{Joshua Tree National Park}

Little San Bernardino Mountains. Represents an area of convergence between desert and non-desert coastal (Southern California Province) habitat; area is wooded which represents a unique community at JOTR with high diversity and high probability of detecting new species.

Pinto Wash/Pinto Dunes. Extremely fragile and unique floristic area located between vast areas of creosote and bursage; only place the fringe-toed lizard occurs; remote with little available information.

Coxcomb / Eagle Mountains. Land is newly acquired with little available information; represents a transition zone between the Mojave and Sonoran biomes; threatened by plans to build a large landfill surrounded on three sides by NPS lands.

Quail Springs Watershed. Significantly and repeatedly over the last 30 years; unusual species starting to appear related to burns; threatened by the invasion of exotic grasses; particularly interested in Smith Water Canyon.

Fan Palm Oases. Represent islands of biodiversity in an otherwise unwatered landscape; all are destination locations for park visitors; threatened by lowered groundwater levels due to urbanization; Fortynine Palms Oasis and Munsen Oasis particularly important.

Lost Horse and Hidden Valleys. Areas never surveyed; rugged and remote. 
Table 1. Priority sampling locations for Mojave Network Park units (continued).

\section{Lake Mead National Recreation Area}

Shivwits Plateau. Large area newly acquired; representative of the Great Basin desert; pinyon-juniper communities with high diversity; little available information, particularly on vertebrate species, due to limited access.

Newberry Mountains. Identified as an area with high probability of detecting new species; represents a Mojave Desert / Sonoran Desert ecotone; high elevation and high diversity; little available information compared to other areas of park.

Black Mountains. Identified as an area with high probability of detecting new species; high elevation and high diversity; little available information compared to other areas of park.

Gold Butte. Identified as an area with high probability of detecting new species; remote location accessible primarily by boat, therefore little information is available; one of two locations in Nevada where Ocotillo occurs naturally; unique in the presence of large patches of sand and high potential for rare or endemic plant species..

Springs. Areas of high diversity; known populations of relict leopard frogs in six springs (40-50 springs total); threatened by the invasion of non-native plant species and visitor use activities.

Sandy benches near water. Species of special concern possibly exist in this very limited habitat, including Chaetodipus penicillatus; represent areas historically beneath water level.

\section{Manzanar National Historic Site}

Riparian Community. Approximately 1 mile of riparian habitat associated with an intermittent stream represents the area of highest diversity at MANZ; highest potential for adding to the species list.

Cottonwood Grove. Approximately 1/3 of the land base of MANZ is covered by a large cottonwood grove due to unique hydrological conditions maintaining water near the surface in this area.

Blackbrush Scrub. Approximately 1/3 of MANZ is dominated by blackbrush scrub type habitat.

\section{Mojave National Preserve}

Springs and Seeps. Identified as having a high potential for adding to the park species list, particularly for bats; represent islands of biodiversity in an otherwise unwatered landscape; spring locations have been ranked based on risk to resources allowing focus of inventory efforts.

Piute Range. Area with Sonoran Desert influence; high potential for adding to park species list; includes a two-mile long perennial stream and associated riparian habitat unique in the park; little information on flora and fauna.

Limestone Substrates and Sand Dunes. High potential for the presence of unique/endemic floristic species and other rare plants and animals.

High elevation areas. Defined as >4,500 feet above sea level; primarily in Clark, New York, and Providence Mountains; presence of pinyon-juniper communities, representing areas of high diversity. 
Table 2. Numbers of museum specimen records of mammal species from the Mojave Network park units. Species are listed alphabetically by scientific name. Park acronyms are: DEVA - Death Valley National Park; JOTR - Joshua Tree National Park; LAME - Lake Mead National Recreation Area; MANZ - Manzanar National Historic Site; MOJA - Mojave National Preserve. See text for details of museum search.

\begin{tabular}{|c|c|c|c|c|c|}
\hline & DEVA & JOTR & LAME & MANZ & MOJA \\
\hline $\begin{array}{l}\text { Harris’ Antelope Squirrel } \\
\quad \text { (Ammospermophilus harrisii) }\end{array}$ & & & 5 & & \\
\hline White-tailed Antelope Squirrel (A. leucurus) & 54 & 3 & 5 & & \\
\hline Pallid Bat (Antrozous pallidus) & 9 & & & & \\
\hline Ringtail (Bassariscus astutus) & 3 & & & & \\
\hline Cattle (Bos sp.) & 2 & & & & \\
\hline Coyote (Canis latrans) & 14 & & & & \\
\hline San Diego Pocket Mouse (Chaetodipus fallax) & & 16 & & & \\
\hline Long-tailed Pocket Mouse (C. formosus) & 103 & 2 & 7 & & \\
\hline Rock Pocket Mouse (C. intermedius) & & & 45 & & \\
\hline Desert Pocket Mouse (C. penicillatus) & 18 & & 5 & & 2 \\
\hline $\begin{array}{l}\text { Townsend's Big-eared Bat } \\
\quad \text { (Corynorhinus townsendii) }\end{array}$ & 2 & & & & 3 \\
\hline Desert Kangaroo Rat (Dipodomys deserti) & 9 & 1 & 35 & & \\
\hline Merriam's Kangaroo Rat (Dipodomys merriami) & 5 & 3 & 26 & & \\
\hline Chisel-toothed Kangaroo Rat (D. microps) & 2 & & & & \\
\hline Panamint Kangaroo Rat (D. panamintinus) & 1 & & & & \\
\hline Porcupine (Erethizon dorsatum) & & & 1 & & \\
\hline Western Mastiff Bat (Eumops perotis) & & 1 & & & \\
\hline Feral Burro (Equus asinus) & 11 & & & & \\
\hline Silver-haired Bat (Lasionycteris noctivagans) & 5 & & & & \\
\hline Western Red Bat (Lasiurus blossevillii) & 1 & & & & \\
\hline Hoary Bat (Lasiurus cinereus) & 4 & 1 & & & \\
\hline Black-tailed Jackrabbit (Lepus californicus) & 3 & & & & \\
\hline Bobcat (Lynx rufus) & 1 & 1 & & & \\
\hline Striped Skunk (Mephitis mephitis) & & & 3 & & \\
\hline California Myotis (Myotis californicus) & 7 & 1 & 2 & & 5 \\
\hline Western Small-footed Myotis (M. ciliolabrum) & 2 & & & & 9 \\
\hline Fringed Myotis (Myotis thysanodes) & 4 & & & & \\
\hline Long-legged Myotis (Myotis volans) & 5 & & & & \\
\hline Yuma Myotis (Myotis yumanensis) & & & 7 & & \\
\hline Cliff Chipmunk (Neotamias dorsalis) & & & 1 & & \\
\hline Panamint Chipmunk (Neotamias panamintinus) & 40 & & & & 50 \\
\hline Uinta Chipmunk (Neotamias umbrinus) & 2 & & & & \\
\hline
\end{tabular}


Table 2. Numbers of museum specimen records from Mojave Network park units (continued).

\begin{tabular}{|c|c|c|c|c|c|}
\hline & DEVA & JOTR & LAME & MANZ & MOJA \\
\hline White-throated Woodrat (Neotoma albigula) & & 1 & & & \\
\hline Arizona Woodrat (Neotoma devia) & & & 39 & & \\
\hline Big-eared Woodrat (Neotoma macrotis) & 2 & 3 & & & \\
\hline Desert Woodrat (Neotoma lepida) & 8 & 3 & & & \\
\hline Crawford's Desert Shrew (Notiosorex crawfordi) & i) 1 & & & & \\
\hline Big Free-tailed Bat (Nyctinomops macrotis) & 1 & & & & \\
\hline Deer (Odocoileus sp.) & 1 & & & & \\
\hline Mule Deer (Odocoileus hemionus) & 12 & & & & \\
\hline $\begin{array}{l}\text { Southern Grasshopper Mouse } \\
\text { (Onychomys torridus) }\end{array}$ & & 2 & 16 & & \\
\hline Sheep (Ovis sp.) & 1 & & & & \\
\hline Bighorn (Ovis canadensis) & 202 & & & & \\
\hline Arizona Pocket Mouse (Perognathus amplus) & & & 16 & & \\
\hline Little Pocket Mouse ( $P$. longimembris) & & 1 & & & \\
\hline Great Basin Pocket Mouse (P. parvus) & 25 & & & & \\
\hline Brush Mouse (Peromyscus boylii) & 1 & 1 & 2 & & 1 \\
\hline Canyon Mouse (Peromyscus crinitus) & 2 & 8 & 16 & & \\
\hline Cactus Mouse (Peromyscus eremicus) & 6 & 2 & 54 & & \\
\hline Deer Mouse (Peromyscus maniculatus) & 13 & 5 & 5 & & \\
\hline White-footed Mouse (Peromyscus sp.) & 6 & 1 & & & \\
\hline Pinyon Mouse (Peromyscus truei) & 1 & 7 & 3 & & 1 \\
\hline Western Pipistrelle (Pipistrellus hesperus) & 3 & 3 & 1 & & \\
\hline Mountain Lion (Puma concolor) & 1 & & & & \\
\hline $\begin{array}{l}\text { Western Harvest Mouse } \\
\quad \text { (Reithrodontomys megalotis) }\end{array}$ & 25 & & 1 & & \\
\hline $\begin{array}{l}\text { California Ground Squirrel } \\
\text { (Spermophilus beecheyi) }\end{array}$ & 10 & 1 & & & \\
\hline Mojave Ground Squirrel (S. mohavensis) & 1 & & & & \\
\hline Round-tailed Ground Squirrel (S. tereticaudus) & 12 & & & & \\
\hline Rock Squirrel (Spermophilus variegatus) & & & & & 11 \\
\hline Desert Cottontail (Sylvilagus audubonii) & 1 & & & & \\
\hline Nuttall’s Cottontail (Sylvilagus nuttallii) & 1 & & & & \\
\hline Brazilian Free-tailed Bat (Tadarida brasiliensis) & 1 & & & & \\
\hline Badger (Taxidea taxus) & & & 2 & & \\
\hline Botta’s Pocket Thomomys bottae) & & 1 & 13 & & \\
\hline Gray Fox (Urocyon cinereoargenteus) & 1 & & & & \\
\hline Kit Fox (Vulpes macrotis) & 8 & & & & \\
\hline
\end{tabular}


Table 3. Mammal field sessions in Mojave Network Parks from 2002 - 2004. Person-days equals the number of working days in the field times the number of field staff working on that trip. Trap nights equals the number of traps deployed, times the number of nights that the traps were open. Park acronyms are the same as in Table 1.

2002 Field Season

\begin{tabular}{lccccc} 
Park & Start Date & End Date & Fld Days & Person-days & Trap Nights \\
\hline MANZ & 24-Apr-02 & 25-Apr-02 & 2 & 4 & 160 \\
DEVA & 29-May-02 & 2-Jun-02 & 4 & 16 & 252 \\
MANZ & 3-Jun-02 & 4-Jun-02 & 1 & 4 & 100 \\
LAME & 12-Jun-02 & 18-Jun-02 & 7 & 21 & 453 \\
MOJA & 30-Jun-02 & 1-Jul-02 & 1 & 2 & 0 \\
JOTR & 1-Jul-02 & 2-Jul-02 & 2 & 6 & 114 \\
MANZ & 21-Aug-02 & 24-Aug-02 & 3 & 9 & 204 \\
MANZ & 24-Sep-02 & & 1 & 2 & 60 \\
MOJA & 25-Sep-02 & 30-Sep-02 & 5 & 10 & 290 \\
JOTR & 10-Oct-02 & 15-Oct-02 & 5 & 10 & 180 \\
DEVA & 23-Oct-02 & 29-Oct-02 & 6 & 18 & 294 \\
LAME & 6-Nov-02 & 10-Nov-02 & 4 & 8 & 30 \\
JOTR & 23-Nov-02 & 23-Nov-02 & 1 & 2 & 60 \\
DEVA & 24-Nov-02 & 25-Nov-02 & 2 & 4 & 70
\end{tabular}

\section{Field Season}

$\begin{array}{lrrrrr}\text { MOJA } & \text { 26-Mar-03 } & \text { 28-Mar-03 } & 2 & 6 & 75 \\ \text { JOTR } & \text { 28-Mar-03 } & \text { 31-Mar-03 } & 4 & 8 & 224 \\ \text { DEVA } & \text { 07-Apr-03 } & \text { 13-Apr-03 } & 7 & 21 & 420 \\ \text { MANZ } & \text { 22-Apr-03 } & \text { 25-Apr-03 } & 3 & 6 & 80 \\ \text { MOJA } & \text { 25-Apr-03 } & \text { 28-Apr-03 } & 4 & 8 & 180 \\ \text { JOTR } & \text { 06-May-03 } & \text { 10-May-03 } & 4 & 8 & 280 \\ \text { LAME } & \text { 10-May-03 } & \text { 13-May-03 } & 4 & 8 & 180 \\ \text { JOTR } & \text { 21-May-03 } & \text { 27-May-03 } & 7 & 30 & 240 \\ \text { LAME } & \text { 03-Jun-03 } & \text { 10-Jun-03 } & 7 & 28 & 470 \\ \text { MOJA } & \text { 17-Jun-03 } & \text { 24-Jun-03 } & 7 & 28 & 110 \\ \text { MOJA } & \text { 23-Sep-03 } & \text { 26-Sep-03 } & 3 & 6 & 40 \\ \text { JOTR } & \text { 26-Sep-03 } & \text { 28-Sep-03 } & 2 & 4 & 40 \\ \text { DEVA } & \text { 07-Oct-03 } & \text { 13-Oct-03 } & 6 & 12 & 410 \\ \text { LAME } & \text { 21-Oct-03 } & \text { 24-Oct-03 } & 3 & 6 & 220 \\ \text { MOJA } & \text { 24-Oct-03 } & \text { 27-Oct-03 } & 3 & 6 & 140 \\ \text { DEVA } & \text { 04-Nov-03 } & \text { 10-Nov-03 } & 6 & 12 & 320\end{array}$


Table 3. Mammal field sessions in Mojave Network Parks from 2002 - 2004 (continued).

\section{Field Season}

$\begin{array}{lrrrrr}\text { DEVA } & \text { 31-Mar-04 } & \text { 05-Apr-04 } & 5 & 13 & 287 \\ \text { DEVA } & \text { 14-Apr-04 } & \text { 16-Apr-04 } & 2 & 4 & 325 \\ \text { MOJA } & \text { 16-Apr-04 } & \text { 19-Apr-04 } & 3 & 9 & 265 \\ \text { MOJA } & \text { 26-Apr-04 } & \text { 30-Apr-04 } & 4 & 8 & 254 \\ \text { JOTR } & \text { 30-Apr-04 } & \text { 03-May-04 } & 3 & 9 & 70 \\ \text { DEVA } & \text { 11-May-04 } & \text { 12-May-04 } & 1 & 2 & 50 \\ \text { MOJA } & \text { 12-May-04 } & \text { 16-May-04 } & 5 & 10 & 198 \\ \text { JOTR } & \text { 08-Jun-04 } & \text { 14-Jun-04 } & 6.5 & 13 & 256 \\ \text { JOTR } & \text { 22-Jun-04 } & \text { 23-Jun-04 } & 1 & 2 & 20 \\ \text { DEVA } & \text { 23-Jun-04 } & \text { 28-Jun-04 } & 5 & 10 & 213 \\ \text { MANZ } & \text { 08-Sep-04 } & \text { 10-Sep-04 } & 3 & 3 & 125\end{array}$


Table 4. Cumulative field sampling effort for mammals at Mojave Network Parks from 2002 - 2004, by Park unit. Park acronyms and definitions are the same as in preceding tables.

\begin{tabular}{lcccc} 
& \# of Visits & Field Days & Person-days & Trap-nights \\
\hline DEVA & 10 & 44 & 112 & 2,397 \\
JOTR & 10 & 35.5 & 92 & 1,492 \\
LAME & 5 & 25 & 71 & 1,313 \\
MANZ & 6 & 13 & 28 & 604 \\
MOJA & 10 & 37 & 93 & 1,538 \\
\hline Total: & $\mathbf{4 1}$ & $\mathbf{1 5 4 . 5}$ & $\mathbf{3 9 6}$ & $\mathbf{7 , 3 4 4}$
\end{tabular}


Table 5. Trap effort and trap success at the Mojave Network Parks from 2002 -- 2004. Trap nights equals the number of traps deployed, times the number of nights that the traps were open. Capture success is the number of captures as a percentage of total trap nights.

Date \# Traps Captures Success (\%)

\section{Death Valley National Park}

\begin{tabular}{lrrr} 
5/30/2002 & 252 & 50 & 20 \\
$10 / 25 / 2002$ & 294 & 8 & 3 \\
$11 / 24 / 2002$ & 70 & 11 & 16 \\
$4 / 8 / 2003$ & 420 & 70 & 17 \\
$10 / 9 / 2003$ & 410 & 87 & 21 \\
$11 / 6 / 2003$ & 320 & 28 & 9 \\
$4 / 1 / 2004$ & 274 & 14 & 5 \\
$4 / 15 / 2004$ & 60 & 11 & 18 \\
$5 / 12 / 2004$ & 50 & 26 & 52 \\
$6 / 24 / 2004$ & 247 & 108 & 44 \\
\hline \multicolumn{2}{r}{ Trap Success, Overall: } & & 17.2
\end{tabular}

Joshua Tree National Park

\begin{tabular}{lrrr}
$7 / 2 / 2002$ & 114 & 17 & 15 \\
$10 / 10 / 2002$ & 180 & 34 & 19 \\
$11 / 23 / 2002$ & 60 & 7 & 12 \\
$3 / 29 / 2003$ & 224 & 27 & 12 \\
$5 / 7 / 2003$ & 280 & 31 & 11 \\
$5 / 22 / 2003$ & 240 & 18 & 8 \\
$9 / 27 / 2003$ & 40 & 3 & 8 \\
$5 / 2 / 2004$ & 80 & 8 & 10 \\
$6 / 9 / 2004$ & 254 & 57 & 22 \\
$6 / 23 / 2004$ & 20 & 16 & 80 \\
\hline \multicolumn{2}{r}{ Trap Success, Overall: } & & 14.6
\end{tabular}

\section{Lake Mead National Recreation Area}

\begin{tabular}{lrrr}
$6 / 12 / 2002$ & 453 & 9 & 2 \\
$11 / 10 / 2002$ & 30 & 18 & 60 \\
$5 / 11 / 2003$ & 140 & 41 & 29 \\
$6 / 4 / 2003$ & 470 & 69 & 15 \\
$10 / 22 / 2003$ & 220 & 53 & 24 \\
\hline \multicolumn{2}{l}{ Trap Success, Overall: } & & 14.5
\end{tabular}


Table 5. Trap effort and trap success at the Mojave Network Parks (continued).

\begin{tabular}{cccc} 
Date & \# Traps & Captures & Success (\%) \\
Manzanar National Historic Site & & \\
4/24/2002 & 160 & 41 & 26 \\
6/4/2002 & 100 & 27 & 27 \\
8/22/2002 & 204 & 27 & 13 \\
9/24/2002 & 60 & 10 & 17 \\
4/24/2003 & 80 & 18 & 23 \\
\multicolumn{2}{r}{ Trap Success, Overall: } & & 20.4
\end{tabular}

\section{Mojave National Preserve}

\begin{tabular}{lrrl}
$7 / 1 / 2002$ & 0 & 0 & $* *$ \\
$9 / 25 / 2002$ & 290 & 48 & 17 \\
$3 / 28 / 2003$ & 75 & 11 & 15 \\
$4 / 26 / 2003$ & 180 & 47 & 26 \\
$6 / 18 / 2003$ & 110 & 23 & 21 \\
$9 / 26 / 2003$ & 40 & 18 & 45 \\
$10 / 26 / 2003$ & 140 & 26 & 19 \\
$4 / 17 / 2004$ & 265 & 31 & 12 \\
$4 / 28 / 2004$ & 240 & 39 & 16 \\
$5 / 13 / 2004$ & 198 & 25 & 13 \\
\hline \multicolumn{2}{c}{ Trap Success, Overall: } & & 17.4
\end{tabular}

$\begin{array}{llll}\text { All Sites: } & 7344 & 1212 & 16.5\end{array}$


Table 6. Cumulative small-mammal captures at Mojave Network Parks, by Park unit, sampling from 2002 through 2004. For each park unit, species are listed by total number of captures.

\section{Death Valley National Park}

Canyon Mouse (Peromyscus crinitus) 79

Deer Mouse (Peromyscus maniculatus) 78

Cactus Mouse (Peromyscus eremicus) 59

Desert Pocket Mouse (Chaetodipus penicillatus) 52

Desert Woodrat (Neotoma lepida) 50

Pinyon Mouse (Peromyscus truei) 47

Long-tailed Pocket Mouse (Chaetodipus formosus) 22

Merriam’s Kangaroo Rat (Dipodomys merriami) 20

Brush Mouse (Peromyscus boylii) 18

Desert Kangaroo Rat (Dipodomys deserti) 12

Great Basin Pocket Mouse (Perognathus parvus) 9

White-footed Mouse sp (Peromyscus sp.) 6

Little Pocket Mouse (Perognathus longimembris) 5

Pocket Mouse sp. (Chaetodipus sp.) 4

Panamint Chipmunk (Neotamias panamintinus) 2

\section{Joshua Tree National Park}

Merriam's Kangaroo Rat (Dipodomys merriami) 77

Pallid Bat (Antrozous pallidus) 53

Little Pocket Mouse (Perognathus longimembris) 45

Cactus Mouse (Peromyscus eremicus) 17

$\begin{array}{ll}\text { San Diego Pocket Mouse (Chaetodipus fallax) } & 16\end{array}$

Desert Woodrat (Neotoma lepida) 16

Canyon Mouse (Peromyscus crinitus) 12

Spiny Pocket Mouse (Chaetodipus spinatus) 11

$\begin{array}{ll}\text { Desert Pocket Mouse (Chaetodipus penicillatus) } & 10\end{array}$

Big Brown Bat (Eptesicus fuscus)

$\begin{array}{ll}\text { Western Pipistrelle (Pipistrellus hesperus) } & 7\end{array}$

Pinyon Mouse (Peromyscus truei) 4

Brush Mouse (Peromyscus boylii) 3

Long-tailed Pocket Mouse (Chaetodipus formosus) 3

White-tailed Antelope Squirrel (Ammospermophilus leucurus) 3

Pocket Mouse sp. (Chaetodipus sp.) 3

Southern Grasshopper Mouse (Onychomys torridus) 2

Yellow Bat (Lasiurus xanthinus) 2

Deer Mouse (Peromyscus maniculatus) 1

California Myotis (Myotis californicus) 1

White-footed Mouse sp. (Peromyscus sp.) 1 
Table 6. Cumulative small-mammal captures at Mojave Network Parks (continued).

\section{Lake Mead National Recreation Area}

Cactus Mouse (Peromyscus eremicus) 79

Canyon Mouse (Peromyscus crinitus) 31

Merriam's Kangaroo Rat (Dipodomys merriami) 16

Desert Woodrat (Neotoma lepida) 11

Long-tailed Pocket Mouse (Chaetodipus formosus) 11

$\begin{array}{ll}\text { Pocket Mouse sp. (Chaetodipus sp.) } & 10\end{array}$

Brush Mouse (Peromyscus boylii) $\quad 8$

Little Pocket Mouse (Perognathus longimembris) 5

House Mouse (Mus musculus) 4

Arizona Woodrat (Neotoma devia) 4

Pinyon Mouse (Peromyscus truei) 3

White-footed Mouse sp. (Peromyscus sp.) 3

Harris’ Antelope Squirrel (Ammospermophilus harrisii) 2

Spiny Pocket Mouse (Chaetodipus spinatus) 1

Desert Kangaroo Rat (Dipodomys deserti) 1

Cliff Chipmunk (Neotamias dorsalis) 1

\section{Manzanar National Historic Site}

Deer Mouse (Peromyscus maniculatus) 42

Merriam's Kangaroo Rat (Dipodomys merriami) 29

Brush Mouse (Peromyscus boylii)

Little Pocket Mouse (Perognathus longimembris) 12

Western Harvest Mouse (Reithrodontomys megalotis) 6

California Vole (Microtus californicus) 2

Southern Grasshopper Mouse (Onychomys torridus) 2

Desert Woodrat (Neotoma lepida) 1

Panamint Kangaroo Rat (Dipodomys panamintinus) 1

White-tailed Antelope Squirrel (Ammospermophilus leucurus) 1 
Table 6. Cumulative small-mammal captures at Mojave Network Parks (continued).

\section{Mojave National Preserve}

Desert Woodrat (Neotoma lepida) 81

Cactus Mouse (Peromyscus eremicus) $\quad 74$

Brush Mouse (Peromyscus boylii ) 50

Canyon Mouse (Peromyscus crinitus) 44

Merriam's Kangaroo Rat (Dipodomys merriami) 28

Western Pipistrelle (Pipistrellus hesperus) 28

California Myotis (Myotis californicus) 15

Pinyon Mouse (Peromyscus truei) 14

Long-tailed Pocket Mouse (Chaetodipus formosus) 13

Desert Pocket Mouse (Chaetodipus penicillatus) 12

Spiny Pocket Mouse (Chaetodipus spinatus) 12

Deer Mouse (Peromyscus maniculatus) 9

White-footed Mouse sp. (Peromyscus sp.)

Desert Kangaroo Rat (Dipodomys deserti) 6

San Diego Pocket Mouse (Chaetodipus fallax) 3

Pocket Mouse sp. (Chaetodipus sp.) 3

Big Brown Bat (Eptesicus fuscus) 3

Little Pocket Mouse (Perognathus longimembris) 2

White-tailed Antelope Squirrel (Ammospermophilus leucurus) 2

Pallid Bat (Antrozous pallidus) 2

Fringed Myotis (Myotis thysanodes) 2

Panamint Kangaroo Rat (Dipodomys panamintinus) 1

Townsend's Big-eared Bat (Corynorhinus townsendii) 1

Long-legged Myotis (Myotis volans) 1 
Table 7. Mammal species list for Death Valley National Park, California, based on recent fieldwork, and review of museum data and other sources. Under 'Park Status' ' $\mathrm{D}$ ' indicates the species has been documented from within park boundaries. Under evidence, $\mathrm{M}=$ museum specimen, $\mathrm{L}=$ literature record, $\mathrm{C}=$ trap capture, and $\mathrm{S}=$ reliable sighting, documented here.

\begin{tabular}{|c|c|c|}
\hline Common name (Scientific name) & Park Status & Evidence \\
\hline \multicolumn{3}{|l|}{ Shrews (Insectivora: Family Soricidae) } \\
\hline Crawford's Desert Shrew (Notiosorex crawfordi) & $\mathrm{D}$ & M, L \\
\hline Merriam's Shrew (Sorex merriami) & Unconfirmed & \\
\hline Inyo Shrew (Sorex tenellus) & Unconfirmed & \\
\hline \multicolumn{3}{|l|}{ Vesper Bats (Chiroptera: Family Vespertilionidae) } \\
\hline Pallid Bat (Antrozous pallidus) & $\mathrm{D}$ & M, L \\
\hline Townsend's Big-eared Bat (Corynorhinus townsendii) & $\mathrm{D}$ & M, L \\
\hline Big Brown Bat (Eptesicus fuscus) & $\mathrm{D}$ & M \\
\hline Spotted Bat (Euderma maculatum) & $\mathrm{D}$ & $\mathrm{L}$ \\
\hline Silver-haired Bat (Lasionycteris noctivagans) & $\mathrm{D}$ & M, L \\
\hline Western Red Bat (Lasiurus blossevillii) & $\mathrm{D}$ & M, \\
\hline Hoary Bat (Lasiurus cinereus) & $\mathrm{D}$ & M, L \\
\hline California Myotis (Myotis californicus) & $\mathrm{D}$ & M, L \\
\hline Western Small-footed Myotis (Myotis ciliolabrum) & $\mathrm{D}$ & M, L \\
\hline Long-eared Myotis (Myotis evotis) & Unconfirmed & \\
\hline Little Brown Myotis (Myotis lucifugus) & Unconfirmed & \\
\hline Fringed Myotis (Myotis thysanodes) & $\mathrm{D}$ & M, L \\
\hline Long-legged Myotis (Myotis volans) & $\mathrm{D}$ & M \\
\hline Yuma Myotis (Myotis yumanensis) & Probably Present & M \\
\hline Western Pipistrelle (Pipistrellus hesperus) & $\mathrm{D}$ & M, L \\
\hline \multicolumn{3}{|l|}{ Free-tailed Bats (Chiroptera: Family Molossidae) } \\
\hline Western Mastiff Bat (Eumops perotis) & Unconfirmed & \\
\hline Big Free-tailed Bat (Nyctinomops macrotis) & $\mathrm{D}$ & M \\
\hline Brazilian Free-tailed Bat (Tadarida brasiliensis) & $\mathrm{D}$ & M, L, S \\
\hline \multicolumn{3}{|l|}{ Hares and Rabbits (Lagomorpha: Family Leporidae) } \\
\hline Black-tailed Jackrabbit (Lepus californicus) & $\mathrm{D}$ & M, L \\
\hline Desert Cottontail (Sylvilagus audubonii) & $\mathrm{D}$ & M, L \\
\hline Mountain (or Nuttall's) Cottontail (Sylvilagus nuttallii) & $\mathrm{D}$ & M, L \\
\hline \multicolumn{3}{|l|}{ Squirrels (Rodentia: Family Sciuridae) } \\
\hline White-tailed Antelope Squirrel (Ammospermophilus leucurus) & $\mathrm{D}$ & M, L \\
\hline Least Chipmunk (Neotamias minimus) & Unconfirmed & \\
\hline Panamint Chipmunk (Neotamias panamintinus) & $\mathrm{D}$ & M, C, L \\
\hline Uinta Chipmunk (Neotamias umbrinus) & $\mathrm{D}$ & M \\
\hline California Ground Squirrel (Spermophilus beecheyi) & $\mathrm{D}$ & M \\
\hline Golden-mantled Ground Squirrel (Spermophilus lateralis) & $\mathrm{D}$ & M \\
\hline Mojave Ground Squirrel (Spermophilus mohavensis) & $\mathrm{D}$ & M \\
\hline Round-tailed Ground Squirrel (Spermophilus tereticaudus) & $\mathrm{D}$ & M, L \\
\hline
\end{tabular}


Table 7. Mammal species list for Death Valley National Park (continued).

Common name (Scientific name)

Park Status

Evidence

Pocket Gophers (Rodentia: Family Geomyidae)

Botta's Pocket Gopher (Thomomys bottae)

$\mathrm{D}$

L

Northern Pocket Gopher (Thomomys talpoides)

Unconfirmed

Pocket Mice and Kangaroo Rats (Rodentia: Family Heteromyidae)

Long-tailed Pocket Mouse (Chaetodipus formosus)

$\mathrm{D}$

M, L, C

Sonoran Desert Pocket Mouse (Chaetodipus penicillatus)

$\mathrm{D}$

Desert Kangaroo Rat (Dipodomys deserti)

$\mathrm{D}$

Merriam's Kangaroo Rat (Dipodomys merriami)

$\mathrm{D}$

Chisel-toothed Kangaroo Rat (Dipodomys microps)

$\mathrm{D}$

Ord's Kangaroo Rat (Dipodomys ordii)

Panamint Kangaroo Rat (Dipodomys panamintinus)

Unconfirmed

Pale Kangaroo Mouse (Microdipodops pallidus)

Little Pocket Mouse (Perognathus longimembris)

Great Basin Pocket Mouse (Perognathus parvus)

D

M, L, C

M, L, C

M, L, C

M, L

Unconfirmed

$\mathrm{D}$

C, L

$\mathrm{D}$

M, C, L

Mice, Rats, and Voles (Rodentia: Family Muridae)

Sagebrush Vole (Lemmiscus curtatus)

Unconfirmed

California Vole (Microtus californicus)

Unconfirmed

House Mouse (Mus musculus)

D

$\mathrm{L}$

Bushy-tailed Woodrat (Neotoma cinerea)

$\mathrm{D}$

$\mathrm{D}$

Desert Woodrat (Neotoma lepida)

Big-eared Woodrat (Neotoma macrotis)

$\mathrm{D}$

Common Muskrat (Ondatra zibethicus)

Southern Grasshopper Mouse (Onychomys torridus)

Brush Mouse (Peromyscus boylii)

Unconfirmed

$\mathrm{D}$

$\mathrm{D}$

Canyon Mouse (Peromyscus crinitus)

D

$\mathrm{D}$

D

D

D

$\mathrm{M}$

M, C, L

$\mathrm{M}$

Deer Mouse (Peromyscus maniculatus)

Pinyon Mouse (Peromyscus truei)

Western Harvest Mouse (Reithrodontomys megalotis)

Jumping Mice (Rodentia: Family Zapodidae)

Western Jumping Mouse (Zapus princeps)

Unconfirmed

New World Porcupines (Rodentia: Erethizontidae)

North American Porcupine (Erethizon dorsatum)

$\mathrm{D}$

L

Dogs, Foxes, and Wolves (Carnivora: Family Canidae)

Coyote (Canis latrans)

D

M, L

Common Gray Fox (Urocyon cinereoargenteus)

$\mathrm{D}$

M, L

Kit Fox (Vulpes macrotis)

D

M, L

Raccoons, Ringtails, and Coatis (Carnivora: Family Procyonidae)

Ringtail (Bassariscus astutus)

D

M, L 
Table 7. Mammal species list for Death Valley National Park (continued).

Common name (Scientific name)

Park Status

Evidence

Weasels, Otters, and Badgers (Carnivora: Family Mustelidae)

Long-tailed Weasel (Mustela frenata)

Badger (Taxidea taxus)

Unconfirmed

$\mathrm{D}$

$\mathrm{L}$

Skunks (Carnivora: Family Mephitidae)

Striped Skunk (Mephitis mephitis)

Western Spotted Skunk (Spilogale gracilis)

Unconfirmed

$\mathrm{D}$

C, L

Cats (Carnivora: Family Felidae)

Mountain Lion (or Puma) (Puma concolor)

$\mathrm{D}$

$\mathrm{D}$

M, L

Bobcat (Lynx rufus)

M, L, S

Horses and Asses (Perissodactyla: Family Equidae)

Feral Ass (Equus asinus)

$\mathrm{D}$

M, L

Wild Horse (Equus caballus)

$\mathrm{D}$

$\mathrm{L}$

Deer (Artiodactyla: Family Cervidae)

Elk (Cervus canadensis)

Unconfirmed

Mule (or Black-tailed) Deer (Odocoileus hemionus)

$\mathrm{D}$

M, L

Cattle, Antelope, Sheep, and Goats (Artiodactyla: Family Bovidae)

Domestic Cattle (Bos taurus)

$\mathrm{D}$

M, L

Goat (Capra hircus)

Bighorn (or Mountain) Sheep (Ovis canadensis)

D

M, L 
Table 8. Mammal species list for Joshua Tree National Park, California, based on recent fieldwork, and review of museum data and other sources. Symbols same as in Table 7.

\begin{tabular}{|c|c|c|}
\hline Common name (Scientific name) & Park Status & Evidence \\
\hline \multicolumn{3}{|l|}{ Shrews (Insectivora: Family Soricidae) } \\
\hline Crawford's Desert Shrew (Notiosorex crawfordi) & $\mathrm{D}$ & C, $\mathrm{L}$ \\
\hline \multicolumn{3}{|l|}{ Leaf-noted Bats (Chiroptera: Family Phyllostomidae) } \\
\hline California Leaf-nosed Bat (Macrotus californicus) & $\mathrm{D}$ & $\mathrm{L}$ \\
\hline \multicolumn{3}{|l|}{ Vesper Bats (Chiroptera: Family Vespertilionidae) } \\
\hline Pallid Bat (Antrozous pallidus) & $\mathrm{D}$ & $\mathrm{C}, \mathrm{L}$ \\
\hline Townsend's Big-eared Bat (Corynorhinus townsendii) & $\mathrm{D}$ & $\mathrm{L}$ \\
\hline Big Brown Bat (Eptesicus fuscus) & $\mathrm{D}$ & C, L \\
\hline Spotted Bat (Euderma maculatum) & $\mathrm{D}$ & $\mathrm{L}$ \\
\hline Silver-haired Bat (Lasionycteris noctivagans) & Unconfirmed & \\
\hline Western Red Bat (Lasiurus blossevillii) & Unconfirmed & \\
\hline Hoary Bat (Lasiurus cinereus) & $\mathrm{D}$ & M, L \\
\hline Western Yellow Bat (Lasiurus xanthinus) & $\mathrm{D}$ & C, $\mathrm{L}$ \\
\hline California Myotis (Myotis californicus) & $\mathrm{D}$ & M, C, L \\
\hline Western Small-footed Myotis (Myotis ciliolabrum) & Unconfirmed & \\
\hline Long-eared Myotis (Myotis evotis) & Unconfirmed & \\
\hline Little Brown Myotis (Myotis lucifugus) & Unconfirmed & \\
\hline Fringed Myotis (Myotis thysanodes) & $\mathrm{D}$ & $\mathrm{L}$, \\
\hline Long-legged Myotis (Myotis volans) & $\mathrm{D}$ & $\mathrm{L}$, \\
\hline Yuma Myotis (Myotis yumanensis) & Unconfirmed & \\
\hline Western Pipistrelle (Pipistrellus hesperus) & $\mathrm{D}$ & M, C, L \\
\hline \multicolumn{3}{|l|}{ Free-tailed Bats (Chiroptera: Family Molossidae) } \\
\hline Western Mastiff (or Western Bonneted) Bat (Eumops perotis) & $\mathrm{D}$ & M, L \\
\hline Pocketed Free-tailed Bat (Nyctinomops femorosaccus) & Unconfirmed & \\
\hline Big Free-tailed Bat (Nyctinomops macrotis) & Probably Present & \\
\hline Brazilian Free-tailed Bat (Tadarida brasiliensis) & Probably Present & \\
\hline \multicolumn{3}{|l|}{ Hares and Rabbits (Lagomorpha: Family Leporidae) } \\
\hline Black-tailed Jackrabbit (Lepus californicus) & $\mathrm{D}$ & M, L \\
\hline Desert Cottontail (Sylvilagus audubonii) & $\mathrm{D}$ & M, L \\
\hline \multicolumn{3}{|l|}{ Squirrels (Rodentia: Family Sciuridae) } \\
\hline White-tailed Antelope Squirrel (Ammospermophilus leucurus) & $\mathrm{D}$ & M, C, L \\
\hline Merriam's Chipmunk (Neotamias merriami) & Unconfirmed & $\mathrm{L}$ \\
\hline California Chipmunk (Neotamias obscurus) & $\mathrm{D}$ & $\mathrm{L}$ \\
\hline California Ground Squirrel (Spermophilus beecheyi) & $\mathrm{D}$ & M, L \\
\hline Round-tailed Ground Squirrel (Spermophilus tereticaudus) & $\mathrm{D}$ & C, L \\
\hline \multicolumn{3}{|l|}{ Pocket Gophers (Rodentia: Family Geomyidae) } \\
\hline Botta's Pocket Gopher (Thomomys bottae) & $\mathrm{D}$ & $\mathrm{C}$ \\
\hline
\end{tabular}


Table 8. Mammal species list for Joshua Tree National Park (continued).

Common name (Scientific name)

Park Status

Evidence

Pocket Mice and Kangaroo Rats (Rodentia: Family Heteromyidae)

San Diego Pocket Mouse (Chaetodipus fallax)

$\mathrm{D}$

Long-tailed Pocket Mouse (Chaetodipus formosus)

Sonoran Desert Pocket Mouse (Chaetodipus penicillatus)

$\mathrm{D}$

$\mathrm{M}, \mathrm{C}$

Spiny Pocket Mouse (Chaetodipus spinatus)

$\mathrm{D}$

$\mathrm{D}$

Desert Kangaroo Rat (Dipodomys deserti)

Merriam's Kangaroo Rat (Dipodomys merriami)

D

D

Chisel-toothed Kangaroo Rat (Dipodomys microps)

Historic?

$\mathrm{M}, \mathrm{C}$

Little Pocket Mouse (Perognathus longimembris)

D

M, C

M, C

$\mathrm{M}$

M, C

$\mathrm{L}$

Mice, Rats, and Voles (Rodentia: Family Muridae)

California Vole (Microtus californicus)

Historic / Unconfirmed

House Mouse (Mus musculus)

D

L

White-throated Woodrat (Neotoma albigula)

D

Desert Woodrat (Neotoma lepida)

D

M

Big-eared Woodrat (Neotoma macrotis)

$\mathrm{D}$

Southern Grasshopper Mouse (Onychomys torridus)

$\mathrm{D}$

Brush Mouse (Peromyscus boylii)

$\mathrm{D}$

Canyon Mouse (Peromyscus crinitus)

D

Cactus Mouse (Peromyscus eremicus)

$\mathrm{D}$

Deer Mouse (Peromyscus maniculatus)

Pinyon Mouse (Peromyscus truei)

Western Harvest Mouse (Reithrodontomys megalotis)

$\mathrm{D}$

$\mathrm{D}$

$\mathrm{D}$

M, C

Dogs, Foxes, and Wolves (Carnivora: Family Canidae)

Coyote (Canis latrans)

$\mathrm{D}$

D

Common Gray Fox (Urocyon cinereoargenteus)

Kit Fox (Vulpes macrotis)

D

M, C

$\mathrm{M}$

M, C

$\mathrm{M}, \mathrm{C}$

M, C

M, C

M, C

M, C

C, L

Bears (Carnivora: Family Ursidae)

Black Bear (Ursus americanus)

D

M, L, S

$\mathrm{D}$

M, L

M, L

Raccoons, Ringtails, and Coatis (Carnivora: Family Procyonidae)

Ringtail (Bassariscus astutus)

D

Unconfirmed

Weasels, Otters, and Badgers (Carnivora: Family Mustelidae)

Long-tailed Weasel (Mustela frenata)

Probably Present

L

Badger (Taxidea taxus)

$\mathrm{D}$

M, L

Skunks (Carnivora: Family Mephitidae)

Striped Skunk (Mephitis mephitis)

Unconfirmed

Western Spotted Skunk (Spilogale gracilis)

D

S, L

Cats (Carnivora: Family Felidae)

Bobcat (Lynx rufus)

$\mathrm{D}$

M, L

Mountain Lion (or Puma) (Puma concolor)

$\mathrm{D}$

M, L 
Table 8. Mammal species list for Joshua Tree National Park (continued).

Common name (Scientific name)

Horses and Asses (Perissodactyla: Family Equidae)

Feral Ass (Equus asinus)

Deer (Artiodactyla: Family Cervidae)

Mule (or Black-tailed) Deer (Odocoileus hemionus)

Cattle, Antelope, Sheep, and Goats (Artiodactyla: Family Bovidae)

Bighorn (or Mountain) Sheep (Ovis canadensis)
Park Status

$\mathrm{D}$

D

D

\section{Evidence}

L

M, L

M, L 
Table 9. Mammal species list for Lake Mead National Recreation Area , Arizona and Nevada, based on recent fieldwork, and review of museum data and other sources. Symbols same as in Table 7.

\begin{tabular}{|c|c|c|}
\hline Common name (Scientific name) & Park Status & Evidence \\
\hline \multicolumn{3}{|l|}{ Shrews (Insectivora: Family Soricidae) } \\
\hline Crawford's Desert Shrew (Notiosorex crawfordi) & $\mathrm{D}$ & $\mathrm{L}$ \\
\hline Merriam's Shrew (Sorex merriami) & Unconfirmed & \\
\hline \multicolumn{3}{|l|}{ New World Leaf-nosed Bats (Chiroptera: Family Phyllostomidae) } \\
\hline California Leaf-nosed Bat (Macrotus californicus) & $\mathrm{D}$ & $\mathrm{L}$ \\
\hline \multicolumn{3}{|l|}{ Vesper Bats (Chiroptera: Family Vespertilionidae) } \\
\hline Pallid Bat (Antrozous pallidus) & $\mathrm{D}$ & $\mathrm{L}$ \\
\hline Townsend's Big-eared Bat (Corynorhinus townsendii) & $\mathrm{D}$ & $\mathrm{L}$ \\
\hline Big Brown Bat (Eptesicus fuscus) & $\mathrm{D}$ & $\mathrm{L}$ \\
\hline Spotted Bat (Euderma maculatum) & Unconfirmed & \\
\hline Allen's Big-eared Bat (Idionycteris phyllotis) & $\mathrm{D}$ & $\mathrm{L}$ \\
\hline Silver-haired Bat (Lasionycteris noctivagans) & Probably Present & $\mathrm{L}$ \\
\hline Western Red Bat (Lasiurus blossevillii) & Probably Present & \\
\hline Hoary Bat (Lasiurus cinereus) & Probably Present & \\
\hline Western Yellow Bat (Lasiurus xanthinus) & Unconfirmed & \\
\hline California Myotis (Myotis californicus) & $\mathrm{D}$ & M, L \\
\hline Western Small-footed Myotis (Myotis ciliolabrum) & Probably Present & \\
\hline Long-eared Myotis (Myotis evotis) & Unconfirmed & \\
\hline Fringed Myotis (Myotis thysanodes) & Probably Present & $\mathrm{L}$ \\
\hline Cave Myotis (Myotis velifer) & Unconfirmed & \\
\hline Long-legged Myotis (Myotis volans) & Probably Present & \\
\hline Yuma Myotis (Myotis yumanensis) & $\mathrm{D}$ & M, L \\
\hline Western Pipistrelle (Pipistrellus hesperus) & $\mathrm{D}$ & $\mathrm{M}, \mathrm{L}, \mathrm{S}$ \\
\hline \multicolumn{3}{|l|}{ Free-tailed Bats (Chiroptera: Family Molossidae) } \\
\hline Western Mastiff (or Western Bonneted) Bat (Eumops perotis) & $\mathrm{D}$ & $\mathrm{L}$ \\
\hline Pocketed Free-tailed Bat (Nyctinomops femorosaccus) & Unconfirmed & $\mathrm{L}$ \\
\hline Big Free-tailed Bat (Nyctinomops macrotis) & $\mathrm{D}$ & $\mathrm{L}$ \\
\hline Brazilian Free-tailed Bat (Tadarida brasiliensis) & $\mathrm{D}$ & $\mathrm{L}$ \\
\hline \multicolumn{3}{|l|}{ Hares and Rabbits (Lagomorpha: Family Leporidae) } \\
\hline Black-tailed Jackrabbit (Lepus californicus) & $\mathrm{D}$ & L, S \\
\hline Desert Cottontail (Sylvilagus audubonii) & $\mathrm{D}$ & $\mathrm{L}$ \\
\hline \multicolumn{3}{|l|}{ Squirrels (Rodentia: Family Sciuridae) } \\
\hline Harris's Antelope Squirrel (Ammospermophilus harrisii) & $\mathrm{D}$ & M, C \\
\hline White-tailed Antelope Squirrel (Ammospermophilus leucurus) & $\mathrm{D}$ & $\mathrm{M}$ \\
\hline Cliff Chipmunk (Neotamias dorsalis) & $\mathrm{D}$ & M, C, S \\
\hline Least Chipmunk (Neotamias minimus) & Unconfirmed & \\
\hline Round-tailed Ground Squirrel (Spermophilus tereticaudus) & $\mathrm{D}$ & M \\
\hline Rock Squirrel (Spermophilus variegatus) & $\mathrm{D}$ & $\mathrm{S}$ \\
\hline
\end{tabular}


Table 9. Mammal species list for Lake Mead National Recreation Area (continued).

Common name (Scientific name)

Park Status

Evidence

Pocket Gophers (Rodentia: Family Geomyidae)

Botta's Pocket Gopher (Thomomys bottae)

$\mathrm{D}$

M,

Pocket Mice and Kangaroo Rats (Rodentia: Family Heteromyidae)

Long-tailed Pocket Mouse (Chaetodipus formosus)

$\mathrm{D}$

M, C

Rock Pocket Mouse (Chaetodipus intermedius)

$\mathrm{D}$

$\mathrm{M}$,

Sonoran Desert Pocket Mouse (Chaetodipus penicillatus)

$\mathrm{D}$

$\mathrm{M}$,

Spiny Pocket Mouse (Chaetodipus spinatus)

$\mathrm{D}$

C

Desert Kangaroo Rat (Dipodomys deserti)

$\mathrm{D}$

M, C

Merriam's Kangaroo Rat (Dipodomys merriami)

D

M, C

Chisel-toothed Kangaroo Rat (Dipodomys microps)

Probably Present

Ord's Kangaroo Rat (Dipodomys ordii)

Arizona Pocket Mouse (Perognathus amplus)

Unconfirmed

Little Pocket Mouse (Perognathus longimembris)

D

$\mathrm{M}$

D

C

Great Basin Pocket Mouse (Perognathus parvus)

Probably Present

Beavers (Rodentia: Family Castoridae)

American Beaver (Castor canadensis)

\section{D}

Mice, Rats, and Voles (Rodentia: Family Muridae)

House Mouse (Mus musculus)

White-throated Woodrat (Neotoma albigula)

Arizona Woodrat (Neotoma devia)

Desert Woodrat (Neotoma lepida)

$\mathrm{D}$

Common Muskrat (Ondatra zibethicus)

Northern Grasshopper Mouse (Onychomys leucogaster)

Southern Grasshopper Mouse (Onychomys torridus)

$\mathrm{D}$

Brush Mouse (Peromyscus boylii)

Canyon Mouse (Peromyscus crinitus)

$\mathrm{D}$

Cactus Mouse (Peromyscus eremicus)

$\mathrm{D}$

Deer Mouse (Peromyscus maniculatus)

Pinyon Mouse (Peromyscus truei)

$\mathrm{D}$

Western Harvest Mouse (Reithrodontomys megalotis)

New World Porcupines (Rodentia: Family Erethizontidae)

North American Porcupine (Erethizon dorsatum)

Dogs, Foxes, and Wolves (Carnivora: Family Canidae)

Coyote (Canis latrans)

Gray Wolf (Canis lupus)

Common Gray Fox (Urocyon cinereoargenteus)

Kit Fox (Vulpes macrotis)

D

D

D

D

Probably Present

D

D

D

Unconfirmed

D

L

D

L

Historic

D

L

C

M, C

C

L

M

M, C

M, C

M, C

$\mathrm{M}$

M, C

M

D 
Table 9. Mammal species list for Lake Mead National Recreation Area (continued).

Common name (Scientific name)

Park Status

Evidence

Raccoons, Ringtails, and Coatis (Carnivora: Family Procyonidae)

Ringtail (Bassariscus astutus)

D

L

Northern Raccoon (Procyon lotor)

D

L

Weasels, Otters, and Badgers (Carnivora: Family Mustelidae)

River Otter (Lontra canadensis)

D / Historic

L

Badger (Taxidea taxus)

$\mathrm{D}$

M, L

Skunks (Carnivora: Family Mephitidae)

White-backed Hog-nosed Skunk (Conepatus leuconotus)

Striped Skunk (Mephitis mephitis)

Western Spotted Skunk (Spilogale gracilis)

Probably Present

L

D

M, L

$\mathrm{D}$

L

Cats (Carnivora: Family Felidae)

Mountain Lion (or Puma) (Puma concolor)

D

L

Bobcat (Lynx rufus)

D

L

Horses and Asses(Perissodactyla: Family Equidae)

Feral Ass (Equus asinus)

$\mathrm{D}$

L, S

Wild Horse (Equus caballus)

D

L

Deer (Artiodactyla: Family Cervidae)

Mule (or Black-tailed) Deer (Odocoileus hemionus)

D

L, S

Pronghorn (Artiodactyla: Family Antilocapridae)

Pronghorn (Antilocapra americana)

Historic?

L

Cattle, Antelope, Sheep, and Goats (Artiodactyla: Family Bovidae)

Domestic Cattle (Bos taurus)

D

L, S

Goat (Capra hircus)

Bighorn (or Mountain) Sheep (Ovis canadensis)

Unconfirmed / Historic

L

D

L, S 
Table 10. Mammal species list for Manzanar National Historic Site, California, based on recent fieldwork, and review of museum data and other sources. Symbols same as in Table 7.

\begin{tabular}{|c|c|c|}
\hline Common name (Scientific name) & Park Status & Evidence \\
\hline \multicolumn{3}{|l|}{ Shrews (Insectivora: Family Soricidae) } \\
\hline Water Shrew (Sorex palustris) & Unconfirmed & \\
\hline \multicolumn{3}{|l|}{ Moles (Insectivora: Family Talpidae) } \\
\hline Broad-footed Mole (Scapanus latimanus) & Unconfirmed & \\
\hline \multicolumn{3}{|l|}{ Vesper Bats (Chiroptera: Family Vespertilionidae) } \\
\hline Pallid Bat (Antrozous pallidus) & Unconfirmed & \\
\hline Big Brown Bat (Eptesicus fuscus) & Probably Present & \\
\hline Silver-haired Bat (Lasionycteris noctivagans) & Unconfirmed & \\
\hline Western Red Bat (Lasiurus blossevillii) & Unconfirmed & \\
\hline Hoary Bat (Lasiurus cinereus) & Probably Present & \\
\hline California Myotis (Myotis californicus) & Probably Present & \\
\hline Western Small-footed Myotis (Myotis ciliolabrum) & Unconfirmed & \\
\hline Little Brown Myotis (Myotis lucifugus) & Probably Present & \\
\hline Fringed Myotis (Myotis thysanodes) & Unconfirmed & \\
\hline Yuma Myotis (Myotis yumanensis) & Probably Present & \\
\hline Western Pipistrelle (Pipistrellus hesperus) & Unconfirmed & \\
\hline \multicolumn{3}{|l|}{ Free-tailed Bats (Chiroptera: Family Molossidae) } \\
\hline Brazilian Free-tailed Bat (Tadarida brasiliensis) & Probably Present & \\
\hline \multicolumn{3}{|l|}{ Hares and Rabbits (Lagomorpha: Family Leporidae) } \\
\hline Black-tailed Jackrabbit (Lepus californicus) & $\mathrm{D}$ & S \\
\hline Desert Cottontail (Sylvilagus audubonii) & $\mathrm{D}$ & $\mathrm{S}$ \\
\hline \multicolumn{3}{|l|}{ Squirrels (Rodentia: Family Sciuridae) } \\
\hline White-tailed Antelope Squirrel (Ammospermophilus leucurus) & $\mathrm{D}$ & $\mathrm{C}, \mathrm{S}$ \\
\hline California Ground Squirrel (Spermophilus beecheyi) & $\mathrm{D}$ & S \\
\hline \multicolumn{3}{|l|}{ Pocket Gophers (Rodentia: Family Geomyidae) } \\
\hline Botta's Pocket Gopher (Thomomys bottae) & $\mathrm{D}$ & S (sign) \\
\hline \multicolumn{3}{|l|}{ Pocket Mice and Kangaroo Rats (Rodentia: Family Heteromyidae) } \\
\hline Merriam's Kangaroo Rat (Dipodomys merriami) & $\mathrm{D}$ & $\mathrm{C}$ \\
\hline Chisel-toothed Kangaroo Rat (Dipodomys microps) & Unconfirmed & \\
\hline Panamint Kangaroo Rat (Dipodomys panamintinus) & $\mathrm{D}$ & $\mathrm{C}$ \\
\hline Little Pocket Mouse (Perognathus longimembris) & $\mathrm{D}$ & $\mathrm{C}$ \\
\hline Great Basin Pocket Mouse (Perognathus parvus) & Unconfirmed & \\
\hline
\end{tabular}


Table 10. Mammal species list for Manzanar National Historic Site (continued).

Common name (Scientific name)

Park Status

Evidence

Mice, Rats, and Voles (Rodentia: Family Muridae)

California Vole (Microtus californicus)

$\mathrm{D}$

C

Long-tailed Vole (Microtus longicaudus)

Unconfirmed

House Mouse (Mus musculus)

Probably Present

Desert Woodrat (Neotoma lepida)

Southern Grasshopper Mouse (Onychomys torridus)

$\mathrm{D}$

C

$\mathrm{D}$

C

Brush Mouse (Peromyscus boylii)

$\mathrm{D}$

C

Deer Mouse (Peromyscus maniculatus)

$\mathrm{D}$

C

Western Harvest Mouse (Reithrodontomys megalotis)

$\mathrm{D}$

C

New World Porcupines (Rodentia: Family Erethizontidae)

North American Porcupine (Erethizon dorsatum)

Unconfirmed

Dogs, Foxes, and Wolves (Carnivora: Family Canidae)

Coyote (Canis latrans)

D

Gray Fox (Urocyon cinereoargenteus)

Probably Present

Kit Fox (Vulpes macrotis)

$\mathrm{D}$

Bears (Carnivora: Family Ursidae)

Black Bear (Ursus americanus)

Unconfirmed

Raccoons, Ringtails, and Coatis (Carnivora: Family Procyonidae)

Northern Raccoon (Procyon lotor)

$\mathrm{D}$

S

Weasels, Otters, and Badgers (Carnivora: Family Mustelidae)

Long-tailed Weasel (Mustela frenata)

Badger (Taxidea taxus)

Unconfirmed

Probably Present

Skunks (Carnivora: Family Mephitidae)

Striped Skunk (Mephitis mephitis)

D

S (road-kill)

Western Spotted Skunk (Spilogale gracilis)

Unconfirmed

Cats (Carnivora: Family Felidae)

Bobcat (Lynx rufus)

Probably Present

Horses and Asses (Perissodactyla: Family Equidae)

Feral Ass (Equus asinus)

Current status?

Pronghorn (Artiodactyla: Family Antilocapridae)

Pronghorn (Antilocapra americana)

Historic?

$\mathrm{L}$

Deer (Artiodactyla: Family Cervidae)

Elk (Cervus canadensis; Tule Elk - C. c. nannodes)

D

Mule Deer (Odocoileus hemionus)

Probably Present 
Table 11. Mammal species list for Mojave National Preserve, California, based on recent fieldwork, and review of museum data and other sources. Symbols same as in Table 7.

\begin{tabular}{|c|c|c|}
\hline Common name (Scientific name) & Park Status & Evidence \\
\hline \multicolumn{3}{|l|}{ Shrews (Insectivora: Family Soricidae) } \\
\hline Crawford's Desert Shrew (Notiosorex crawfordi) & $\mathrm{D}$ & $\mathrm{L}$ \\
\hline \multicolumn{3}{|l|}{ New World Leaf-nosed Bats (Chiroptera: Family Phyllostomidae) } \\
\hline California Leaf-nosed Bat (Macrotus californicus) & Unconfirmed & \\
\hline \multicolumn{3}{|l|}{ Vesper Bats (Chiroptera: Family Vespertilionidae) } \\
\hline Pallid Bat (Antrozous pallidus) & $\mathrm{D}$ & C, $L$ \\
\hline Townsend's Big-eared Bat (Corynorhinus townsendii) & $\mathrm{D}$ & M, C, L \\
\hline Big Brown Bat (Eptesicus fuscus) & $\mathrm{D}$ & C, L \\
\hline Spotted Bat (Euderma maculatum) & Probably Present & \\
\hline Western Red Bat (Lasiurus blossevillii) & Unconfirmed & \\
\hline Hoary Bat (Lasiurus cinereus) & $\mathrm{D}$ & $\mathrm{L}$ \\
\hline California Myotis (Myotis californicus) & $\mathrm{D}$ & M, C, L \\
\hline Western Small-footed Myotis (Myotis ciliolabrum) & $\mathrm{D}$ & M, L \\
\hline Fringed Myotis (Myotis thysanodes) & $\mathrm{D}$ & $C, \mathrm{~L}$ \\
\hline Long-legged Myotis (Myotis volans) & $\mathrm{D}$ & C, $\mathrm{L}$ \\
\hline Yuma Myotis (Myotis yumanensis) & Probably Present & \\
\hline Western Pipistrelle (Pipistrellus hesperus) & $\mathrm{D}$ & C, $\mathrm{L}$ \\
\hline \multicolumn{3}{|l|}{ Free-tailed Bats (Chiroptera: Family Molossidae) } \\
\hline Western Mastiff (or Western Bonneted) Bat (Eumops perotis) & Probably Present & \\
\hline Pocketed Free-tailed Bat (Nyctinomops femorosaccus) & Unconfirmed & \\
\hline Big Free-tailed Bat (Nyctinomops macrotis) & Unconfirmed & \\
\hline Brazilian Free-tailed Bat (Tadarida brasiliensis) & $\mathrm{D}$ & $\mathrm{L}$ \\
\hline \multicolumn{3}{|l|}{ Hares and Rabbits (Lagomorpha: Family Leporidae) } \\
\hline Black-tailed Jackrabbit (Lepus californicus) & $\mathrm{D}$ & $\mathrm{L}$ \\
\hline Desert Cottontail (Sylvilagus audubonii) & $\mathrm{D}$ & $\mathrm{L}, \mathrm{S}$ \\
\hline Mountain (or Nuttall's) Cottontail (Sylvilagus nuttallii) & Status not determined & \\
\hline \multicolumn{3}{|l|}{ Squirrels (Rodentia: Family Sciuridae) } \\
\hline White-tailed Antelope Squirrel (Ammospermophilus leucurus) & $\mathrm{D}$ & C, L, S \\
\hline Panamint Chipmunk (Neotamias panamintinus) & $\mathrm{D}$ & $M, L$ \\
\hline Round-tailed Ground Squirrel (Spermophilus tereticaudus) & $\mathrm{D}$ & $\mathrm{L}$ \\
\hline Rock Squirrel (Spermophilus variegatus) & $\mathrm{D}$ & M, L \\
\hline \multicolumn{3}{|l|}{ Pocket Gophers (Rodentia: Family Geomyidae) } \\
\hline Botta's Pocket Gopher (Thomomys bottae) & $\mathrm{D}$ & $\mathrm{L}$ \\
\hline \multicolumn{3}{|l|}{ Pocket Mice and Kangaroo Rats (Rodentia: Family Heteromyidae) } \\
\hline Long-tailed Pocket Mouse (Chaetodipus formosus) & $\mathrm{D}$ & $\mathrm{C}, \mathrm{L}$ \\
\hline Sonoran Desert Pocket Mouse (Chaetodipus penicillatus) & $\mathrm{D}$ & M, C \\
\hline Spiny Pocket Mouse (Chaetodipus spinatus) & $\mathrm{D}$ & C, $\mathrm{L}$ \\
\hline Desert Kangaroo Rat (Dipodomys deserti) & $\mathrm{D}$ & $\mathrm{C}, \mathrm{L}$ \\
\hline
\end{tabular}


Table 11. Mammal species list for Mojave National Preserve (continued).

\begin{tabular}{|c|c|c|}
\hline Common name (Scientific name) & Park Status & Evidence \\
\hline Merriam's Kangaroo Rat (Dipodomys merriami) & $\mathrm{D}$ & $\mathrm{C}, \mathrm{L}$ \\
\hline Chisel-toothed Kangaroo Rat (Dipodomys microps) & $\mathrm{D}$ & $\mathrm{L}$ \\
\hline Panamint Kangaroo Rat (Dipodomys panamintinus) & $\mathrm{D}$ & C, L \\
\hline Little Pocket Mouse (Perognathus longimembris) & $\mathrm{D}$ & $\mathrm{C}, \mathrm{L}$ \\
\hline Great Basin Pocket Mouse (Perognathus parvus) & Unconfirmed & \\
\hline \multicolumn{3}{|l|}{ Mice, Rats, and Voles (Rodentia: Family Muridae) } \\
\hline Bushy-tailed Woodrat (Neotoma cinerea) & Unconfirmed & \\
\hline Desert Woodrat (Neotoma lepida) & $\mathrm{D}$ & $\mathrm{C}, \mathrm{L}$ \\
\hline Big-eared Woodrat (Neotoma macrotis) & $\mathrm{D}$ & $\mathrm{L}$ \\
\hline Southern Grasshopper Mouse (Onychomys torridus) & $\mathrm{D}$ & $\mathrm{L}$ \\
\hline Brush Mouse (Peromyscus boylii) & $\mathrm{D}$ & M, C, L \\
\hline Canyon Mouse (Peromyscus crinitus) & $\mathrm{D}$ & $\mathrm{C}, \mathrm{L}$ \\
\hline Cactus Mouse (Peromyscus eremicus) & $\mathrm{D}$ & $\mathrm{C}, \mathrm{L}$ \\
\hline Deer Mouse (Peromyscus maniculatus) & $\mathrm{D}$ & C, $\mathrm{L}$ \\
\hline Pinyon Mouse (Peromyscus truei) & $\mathrm{D}$ & M, C, L \\
\hline Western Harvest Mouse (Reithrodontomys megalotis) & $\mathrm{D}$ & $\mathrm{L}$ \\
\hline \multicolumn{3}{|l|}{ New World Porcupines (Rodentia: Family Erethizontidae) } \\
\hline North American Porcupine (Erethizon dorsatum) & $\mathrm{D}$ & $\mathrm{L}$ \\
\hline \multicolumn{3}{|l|}{ Dogs, Foxes, and Wolves (Carnivora: Family Canidae) } \\
\hline Coyote (Canis latrans) & $\mathrm{D}$ & $\mathrm{S}, \mathrm{L}$ \\
\hline Gray Wolf (Canis lupus) & Historic & $\mathrm{L}$ \\
\hline Common Gray Fox (Urocyon cinereoargenteus) & $\mathrm{D}$ & $\mathrm{L}$ \\
\hline Kit Fox (Vulpes macrotis) & $\mathrm{D}$ & $\mathrm{L}$ \\
\hline \multicolumn{3}{|l|}{ Raccoons, Ringtails, and Coatis (Carnivora: Family Procyonidae) } \\
\hline Ringtail (Bassariscus astutus) & $\mathrm{D}$ & $\mathrm{L}$ \\
\hline \multicolumn{3}{|l|}{ Weasels, Otters, and Badgers (Carnivora: Family Mustelidae) } \\
\hline Badger (Taxidea taxus) & $\mathrm{D}$ & $\mathrm{L}$ \\
\hline \multicolumn{3}{|l|}{ Skunks (Carnivora: Family Mephitidae) } \\
\hline Striped Skunk (Mephitis mephitis) & Unconfirmed & \\
\hline Western Spotted Skunk (Spilogale gracilis) & $\mathrm{D}$ & $\mathrm{L}$ \\
\hline \multicolumn{3}{|l|}{ Cats (Carnivora: Family Felidae) } \\
\hline Bobcat (Lynx rufus) & $\mathrm{D}$ & $\mathrm{L}$ \\
\hline Mountain Lion (or Puma) (Puma concolor) & $\mathrm{D}$ & $\mathrm{L}$ \\
\hline \multicolumn{3}{|l|}{ Horses and Asses (Perissodactyla: Family Equidae) } \\
\hline Feral Ass (Equus asinus) & $\mathrm{D}$ & $\mathrm{L}, \mathrm{S}$ \\
\hline Wild Horse (Equus caballus) & $\mathrm{D}$ & $\mathrm{L}$ \\
\hline \multicolumn{3}{|l|}{ Deer (Artiodactyla: Family Cervidae) } \\
\hline Mule (or Black-tailed) Deer (Odocoileus hemionus) & $\mathrm{D}$ & $\mathrm{L}$ \\
\hline \multicolumn{3}{|c|}{ Cattle, Antelope, Sheep, and Goats (Artiodactyla: Family Bovidae) } \\
\hline Bighorn (or Mountain) Sheep (Ovis canadensis) & $\mathrm{D}$ & $\mathrm{L}, \mathrm{S}$ \\
\hline Domestic Cattle (Bos taurus) & $\mathrm{D}$ & $\mathrm{L}, \mathrm{S}$ \\
\hline
\end{tabular}


Figure 1. Quarterly precipitation for the area of the Mojave Network park units, 2001 - 2005. Data are for Furnace Creek / Park Headquarters area of Death Valley N. P., Temple Bar on the south side of the Colorado River in Lake Mead N.R.A., the town of Baker, on the northwest margin of Mojave National Preserve, and the town of Twentynine Palms, on the north side of Joshua Tree National Park. Note that the y-axes differ by area.

Figure 2. House mouse (Mus musculus) from Blue Point Spring, Lake Mead National Recreation Area, October 2003.

Figure 3. California vole (Microtus californicus) at Manzanar National Historic Site, April 2002. The voles at Manzanar are the "Owens Valley vole” subspecies, which is a California Special Concern species.

Figure 4. Spiny pocket mouse (Chaetodipus spinatus) from Piute Springs, Mojave National Preserve, September 2002. 


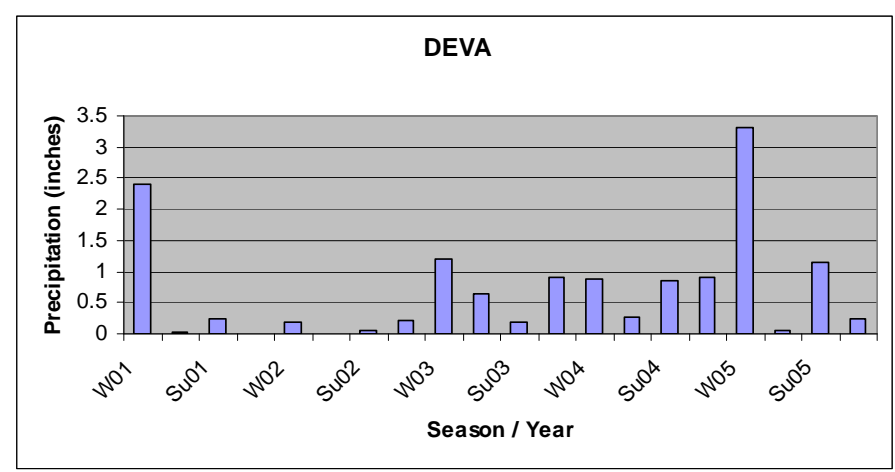

Furnace Creek - Death Valley National Park

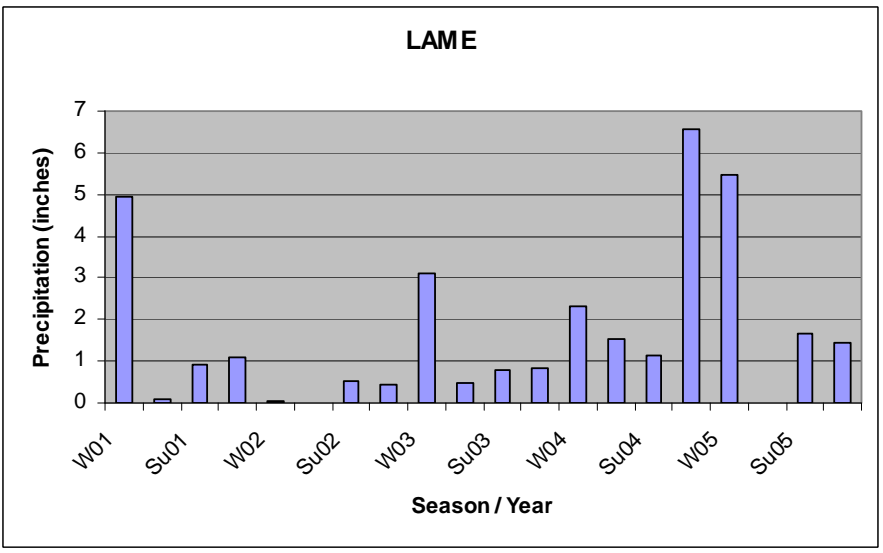

Temple Bar - Lake Mead National Recreation Area

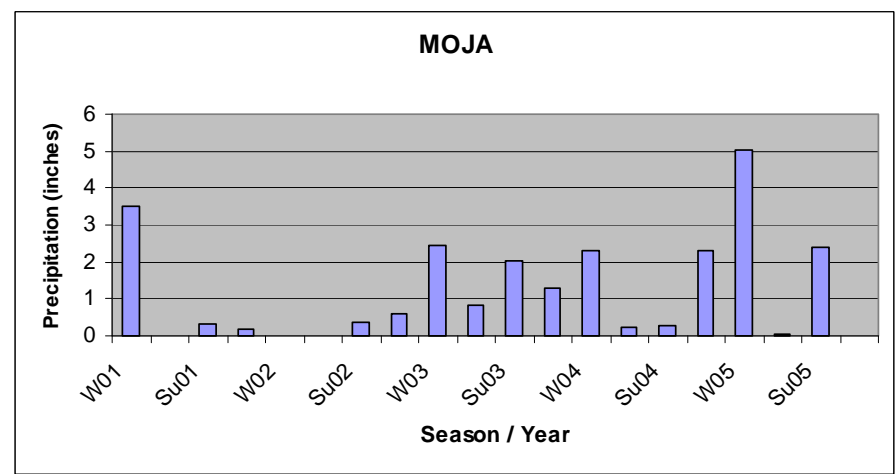

Baker - Northwest edge of Mojave National Preserve

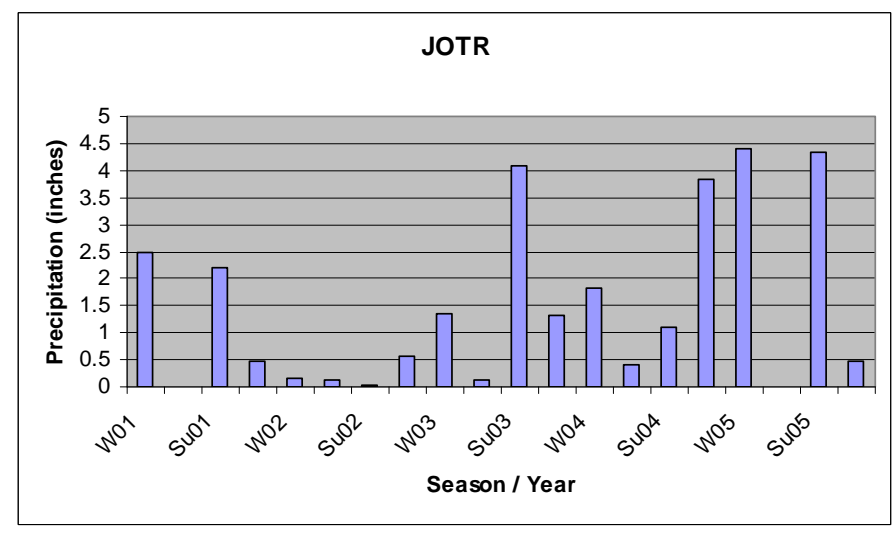

Figure 1.

Twentynine Palms - North side of Joshua Tree National Park 


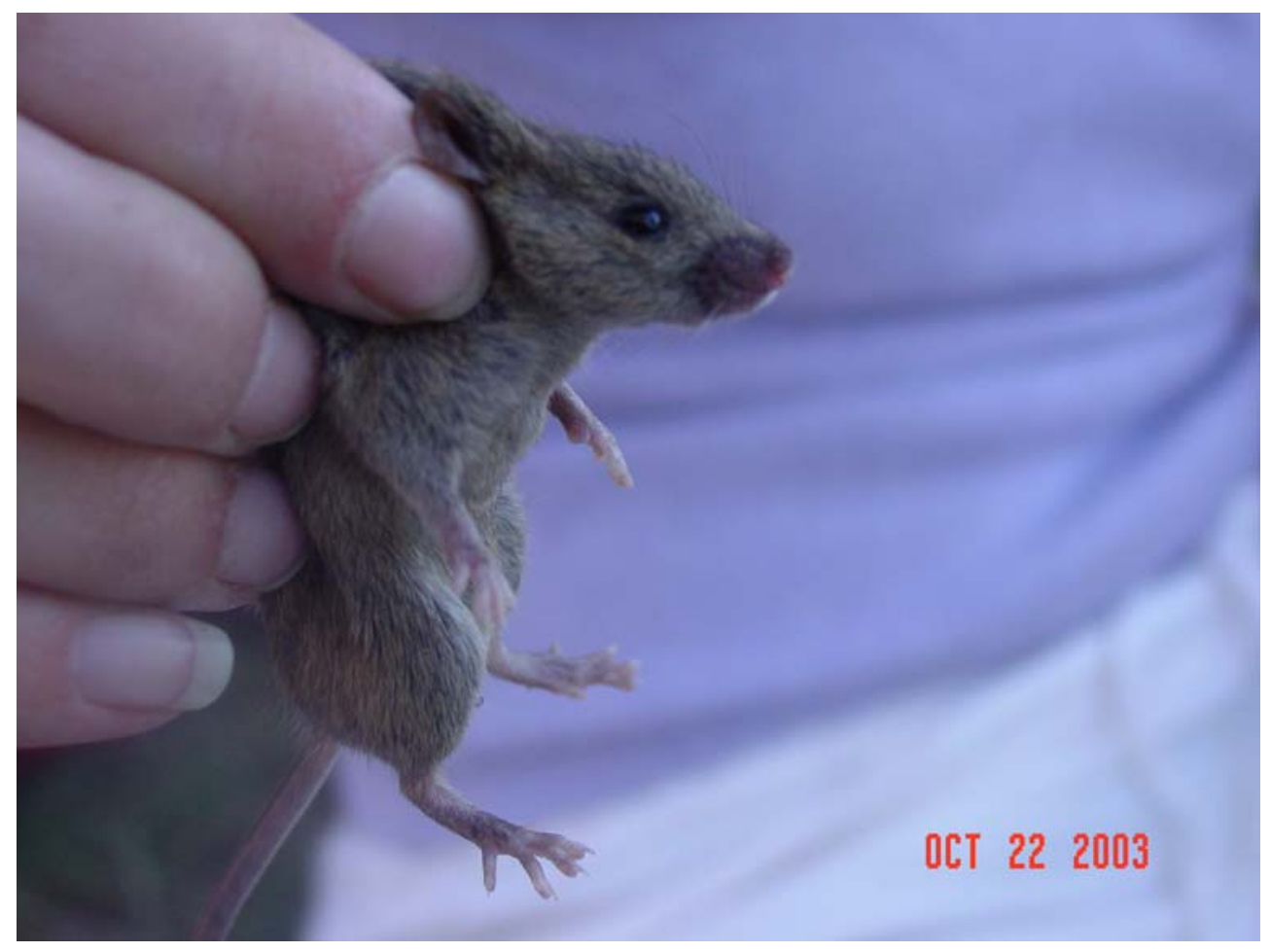

Figure 2.

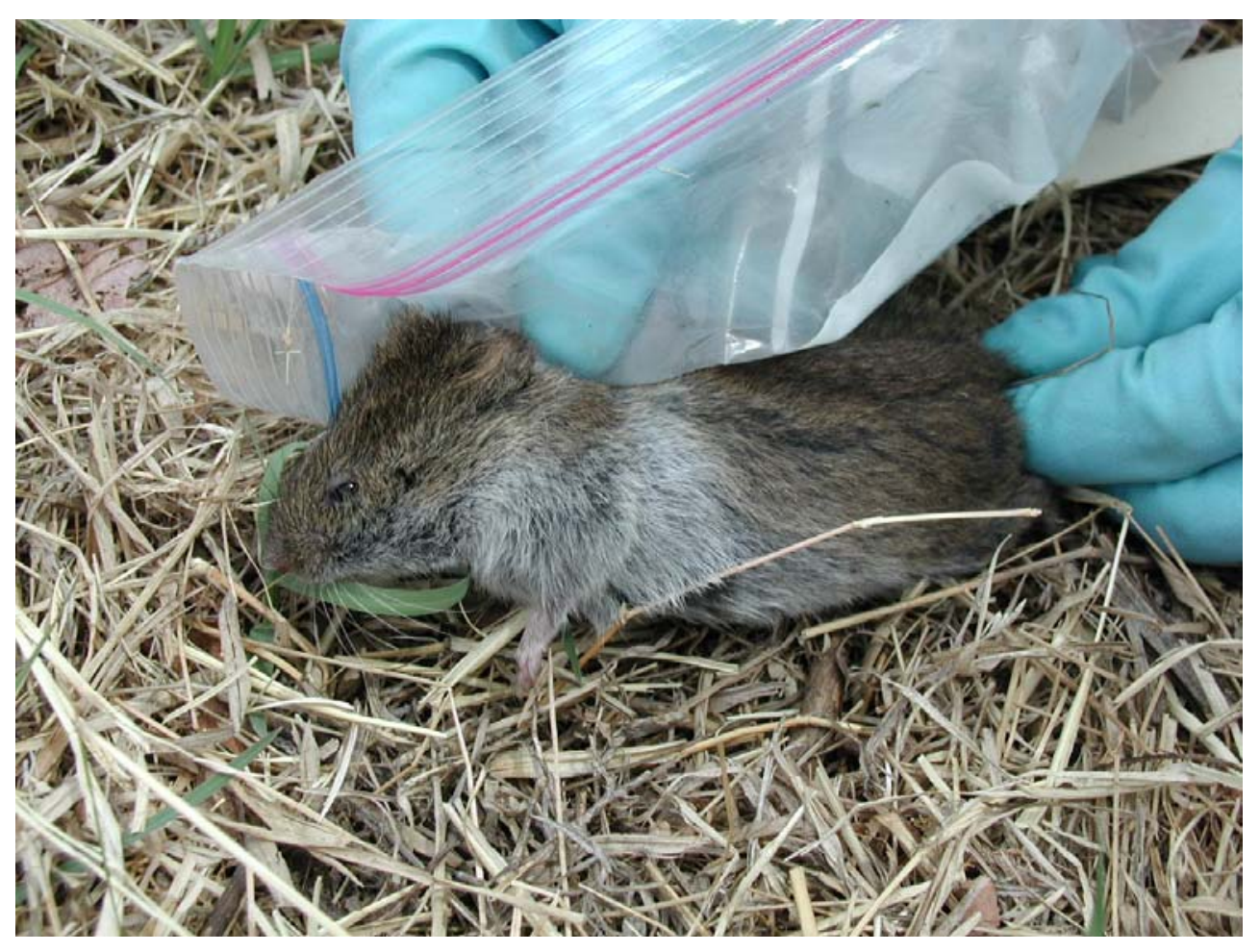

Figure 3. 


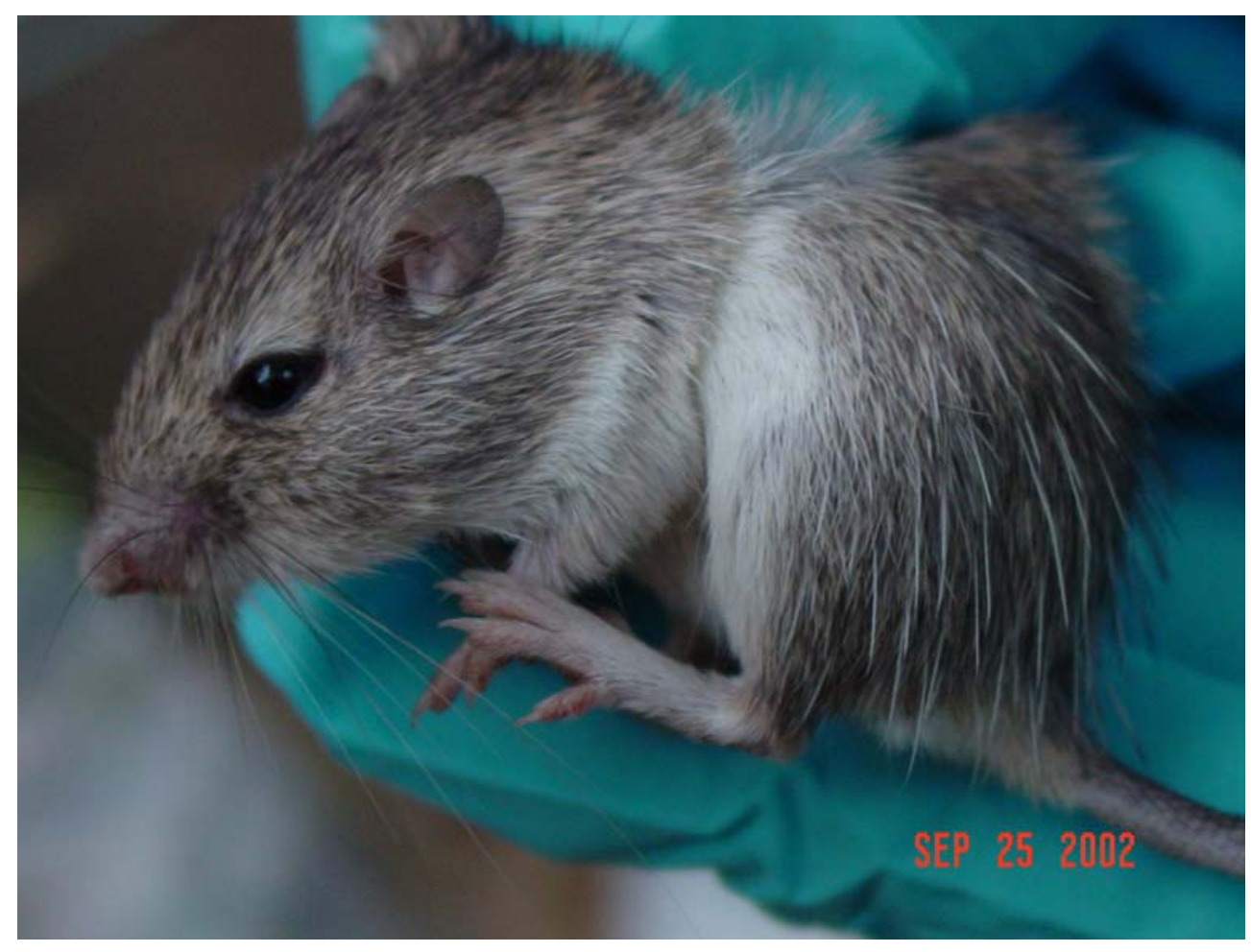

Figure 4 


\section{Appendices}

Appendix 1. Hypothetical mammal species list for Death Valley National Park, California. This list was prepared at the outset of an inventory study conducted from $2002-2006$, and served as a guide for targeting field sampling, and as a point of comparison for inventory completeness. Under Status, "D" indicates species has been documented from park, and " $L$," " $M$," and " $H$ " denote low, medium, and high potential of occurrence. Under evidence, "L" = literature record and "M" = museum specimen.

\begin{tabular}{|c|c|c|}
\hline Common name (Scientific name) & Park Status & Evidence \\
\hline \multicolumn{3}{|l|}{ Shrews (Insectivora: Family Soricidae) } \\
\hline Crawford's Desert Shrew (Notiosorex crawfordi) & $\mathrm{D}$ & M, L \\
\hline Merriam's Shrew (Sorex merriami) & Potential (M) & \\
\hline Inyo Shrew (Sorex tenellus) & Potential (M) & \\
\hline \multicolumn{3}{|l|}{ Moles (Insectivora: Family Talpidae) } \\
\hline Broad-footed Mole (Scapanus latimanus) & Potential ? & \\
\hline \multicolumn{3}{|l|}{ Vesper Bats (Chiroptera: Family Vespertilionidae) } \\
\hline Pallid Bat (Antrozous pallidus) & $\mathrm{D}$ & $M, L$ \\
\hline Townsend's Big-eared Bat (Corynorhinus townsendii) & $\mathrm{D}$ & M, L \\
\hline Big Brown Bat (Eptesicus fuscus) & $\mathrm{D}$ & M \\
\hline Spotted Bat (Euderma maculatum) & $\mathrm{D}$ & $\mathrm{L}$ \\
\hline Silver-haired Bat (Lasionycteris noctivagans) & $\mathrm{D}$ & M, L \\
\hline Western Red Bat (Lasiurus blossevillii) & $\mathrm{D}$ & M, \\
\hline Hoary Bat (Lasiurus cinereus) & $\mathrm{D}$ & M, L \\
\hline California Myotis (Myotis californicus) & $\mathrm{D}$ & M, L \\
\hline Western Small-footed Myotis (Myotis ciliolabrum) & $\mathrm{D}$ & M, L \\
\hline Long-eared Myotis (Myotis evotis) & Potential (M) & Status? \\
\hline Little Brown Myotis (Myotis lucifugus) & Potential (M) & $\mathrm{D}$ ? \\
\hline Fringed Myotis (Myotis thysanodes) & $\mathrm{D}$ & M, L \\
\hline Long-legged Myotis (Myotis volans) & $\mathrm{D}$ & M \\
\hline Yuma Myotis (Myotis yumanensis) & Potential $(\mathrm{H})$ & $\mathrm{D}$ ? (see) \\
\hline Western Pipistrelle (Pipistrellus hesperus) & $\mathrm{D}$ & M, L \\
\hline \multicolumn{3}{|l|}{ Free-tailed Bats (Chiroptera: Family Molossidae) } \\
\hline Western Mastiff Bat (Eumops perotis) & Potential (H?) & \\
\hline Big Free-tailed Bat (Nyctinomops macrotis) & $\mathrm{D}$ & M, \\
\hline Brazilian Free-tailed Bat (Tadarida brasiliensis) & $\mathrm{D}$ & M, L, S \\
\hline \multicolumn{3}{|l|}{ Hares and Rabbits (Lagomorpha: Family Leporidae) } \\
\hline Pygmy Rabbit (Brachylagus idahoensis) & Potential (M) & \\
\hline Black-tailed Jackrabbit (Lepus californicus) & $\mathrm{D}$ & M, L \\
\hline Desert Cottontail (Sylvilagus audubonii) & $\mathrm{D}$ & M, L \\
\hline Mountain (or Nuttall's) Cottontail (Sylvilagus nuttallii) & $\mathrm{D}$ & M, L \\
\hline \multicolumn{3}{|l|}{ Squirrels (Rodentia: Family Sciuridae) } \\
\hline White-tailed Antelope Squirrel (Ammospermophilus leucurus) & $\mathrm{D}$ & M, L \\
\hline Least Chipmunk (Neotamias minimus) & Potential (M) & \\
\hline Panamint Chipmunk (Neotamias panamintinus) & $\mathrm{D}$ & $M, C, L$ \\
\hline Uinta Chipmunk (Neotamias umbrinus) & $\mathrm{D}$ & M \\
\hline California Ground Squirrel (Spermophilus beecheyi) & $\mathrm{D}$ & M \\
\hline
\end{tabular}


Golden-mantled Ground Squirrel (Spermophilus lateralis)

Mojave Ground Squirrel (Spermophilus mohavensis)

Round-tailed Ground Squirrel (Spermophilus tereticaudus)

Pocket Gophers (Rodentia: Family Geomyidae)

Botta's Pocket Gopher (Thomomys bottae)

Northern Pocket Gopher (Thomomys talpoides)

Pocket Mice and Kangaroo Rats (Rodentia: Family Heteromyidae)

Long-tailed Pocket Mouse (Chaetodipus formosus)

Sonoran Desert Pocket Mouse (Chaetodipus penicillatus)

Desert Kangaroo Rat (Dipodomys deserti)

Merriam's Kangaroo Rat (Dipodomys merriami)

Chisel-toothed Kangaroo Rat (Dipodomys microps)

Ord's Kangaroo Rat (Dipodomys ordii)

Panamint Kangaroo Rat (Dipodomys panamintinus)

Pale Kangaroo Mouse (Microdipodops pallidus)

Little Pocket Mouse (Perognathus longimembris)

Great Basin Pocket Mouse (Perognathus parvus)

Mice, Rats, and Voles (Rodentia: Family Muridae)

Sagebrush Vole (Lemmiscus curtatus)

California Vole (Microtus californicus)

Mountain Vole (Microtus montanus)

House Mouse (Mus musculus)

Bushy-tailed Woodrat (Neotoma cinerea)

Desert Woodrat (Neotoma lepida)

Big-eared Woodrat (Neotoma macrotis)

Common Muskrat (Ondatra zibethicus)

Southern Grasshopper Mouse (Onychomys torridus)

Brush Mouse (Peromyscus boylii)

Canyon Mouse (Peromyscus crinitus)

Cactus Mouse (Peromyscus eremicus)

Deer Mouse (Peromyscus maniculatus)

Pinyon Mouse (Peromyscus truei)

Western Harvest Mouse (Reithrodontomys megalotis)

Jumping Mice (Rodentia: Family Zapodidae)

Western Jumping Mouse (Zapus princeps)

New World Porcupines (Rodentia: Erethizontidae)

North American Porcupine (Erethizon dorsatum)

Dogs, Foxes, and Wolves (Carnivora: Family Canidae)

Coyote (Canis latrans)

Common Gray Fox (Urocyon cinereoargenteus)

Kit Fox (Vulpes macrotis)

\section{D}

$\mathrm{D}$

D

D

Potential (M?)

$\mathrm{D}$

$\mathrm{D}$

$\mathrm{D}$

$\mathrm{D}$

D

Potential (M)

D

Potential (M / H)

D

D

Potential (M / H?)

Potential (M / H)

Potential (L)

D

(Kingsley notes Mus at Scotty's C.)

$\mathrm{D}$ ?

D

$\mathrm{D}$

Potential (M)

D

$\mathrm{D}$

D

$\mathrm{D}$

$\mathrm{D}$

D

D

Potential (M)

D

(Kingsley, Miller)

D

D

D
C, L

M, C, L 
Raccoons, Ringtails, and Coatis (Carnivora: Family Procyonidae)

Ringtail (Bassariscus astutus)

D

Potential (L?)

Weasels, Otters, and Badgers (Carnivora: Family Mustelidae)

Long-tailed Weasel (Mustela frenata)

Badger (Taxidea taxus)

Skunks (Carnivora: Family Mephitidae)

Striped Skunk (Mephitis mephitis)

Western Spotted Skunk (Spilogale gracilis)

Cats (Carnivora: Family Felidae)

Mountain Lion (or Puma) (Puma concolor)

Bobcat (Lynx rufus)

Horses and Asses (Perissodactyla: Family Equidae)

Feral Ass (Equus asinus)

Wild Horse (Equus caballus)

Deer (Artiodactyla: Family Ceridae)

Elk (Cervus canadensis)

Mule (or Black-tailed) Deer (Odocoileus hemionus)

Cattle, Antelope, Sheep, and Goats (Artiodactyla: Family Bovidae)

Domestic Cattle (Bos taurus)

Goat (Capra hircus)

Bighorn (or Mountain) Sheep (Ovis canadensis)
Potential (M)

$\mathrm{D}$

$\mathrm{L}$

Potential (M)

$\mathrm{D}$

C, L

$\mathrm{D}$

$\mathrm{D}$

M, L

M, L, S

D

D

M, L

$\mathrm{L}$

Potential (L?)

D

M, L

D

M, L

D

M, L 
Appendix 2. Hypothetical mammal species list for Joshua Tree National Park, California, prepared as a guide for an inventory study conducted in 2002-2006. Under Status, "D" indicates species has been documented from park, and "L," "M," and " $H$ " denote low, medium, and high potential of occurrence. Under evidence, "L" = literature record and " $M$ " = museum specimen.

\begin{tabular}{|c|c|c|}
\hline Common name (Scientific name) & Park Status & Evidence \\
\hline \multicolumn{3}{|l|}{ Shrews (Insectivora: Family Soricidae) } \\
\hline Crawford's Desert Shrew (Notiosorex crawfordi) & $\mathrm{D}$ & C, L \\
\hline \multicolumn{3}{|l|}{ Vesper Bats (Chiroptera: Family Vespertilionidae) } \\
\hline Pallid Bat (Antrozous pallidus) & $\mathrm{D}$ & C, $\mathrm{L}$ \\
\hline Townsend's Big-eared Bat (Corynorhinus townsendii) & $\mathrm{D}$ & $\mathrm{L}$ \\
\hline Big Brown Bat (Eptesicus fuscus) & $\mathrm{D}$ & C, L \\
\hline Spotted Bat (Euderma maculatum) & $\mathrm{D}$ & $\mathrm{L}$ \\
\hline Silver-haired Bat (Lasionycteris noctivagans) & Potential (M) & \\
\hline Western Red Bat (Lasiurus blossevillii) & Potential (M) & \\
\hline Hoary Bat (Lasiurus cinereus) & $\mathrm{D}$ & M, L \\
\hline Western Yellow Bat (Lasiurus xanthinus) & $\mathrm{D}$ & C, L \\
\hline California Leaf-nosed Bat (Macrotus californicus) & $\mathrm{D}$ & $\mathrm{L}$ \\
\hline California Myotis (Myotis californicus) & $\mathrm{D}$ & M, C, L \\
\hline Western Small-footed Myotis (Myotis ciliolabrum) & Potential (M) & ?? \\
\hline Long-eared Myotis (Myotis evotis) & Potential (L) & \\
\hline Fringed Myotis (Myotis thysanodes) & $\mathrm{D}$ & $\mathrm{L}$, \\
\hline Long-legged Myotis (Myotis volans) & $\mathrm{D}$ & $\mathrm{L}$, \\
\hline Yuma Myotis (Myotis yumanensis) & Potential (M?) & \\
\hline Western Pipistrelle (Pipistrellus hesperus) & $\mathrm{D}$ & M, C, L \\
\hline \multicolumn{3}{|l|}{ Free-tailed Bats (Chiroptera: Family Molossidae) } \\
\hline Western Mastiff (or Western Bonneted) Bat (Eumops perotis) & $\mathrm{D}$ & M, L \\
\hline Pocketed Free-tailed Bat (Nyctinomops femorosaccus) & Potential (M?) & \\
\hline Big Free-tailed Bat (Nyctinomops macrotis) & Potential $(\mathrm{H})$ & \\
\hline Brazilian Free-tailed Bat (Tadarida brasiliensis) & Potential $(\mathrm{H})$ & \\
\hline \multicolumn{3}{|l|}{ Hares and Rabbits (Lagomorpha: Family Leporidae) } \\
\hline Black-tailed Jackrabbit (Lepus californicus) & $\mathrm{D}$ & M, L \\
\hline Desert Cottontail (Sylvilagus audubonii) & $\mathrm{D}$ & M, L \\
\hline \multicolumn{3}{|l|}{ Squirrels (Rodentia: Family Sciuridae) } \\
\hline White-tailed Antelope Squirrel (Ammospermophilus leucurus) & $\mathrm{D}$ & M, C, L \\
\hline Merriam's Chipmunk (Neotamias merriami) & D / Unconfirmed? & $\mathrm{L}$ ? \\
\hline California Chipmunk (Neotamias obscurus) & $\mathrm{D}$ & $\mathrm{L}$ \\
\hline California Ground Squirrel (Spermophilus beecheyi) & $\mathrm{D}$ & M, L \\
\hline Round-tailed Ground Squirrel (Spermophilus tereticaudus) & $\mathrm{D}$ & C, L \\
\hline \multicolumn{3}{|l|}{ Pocket Gophers (Rodentia: Family Geomyidae) } \\
\hline Botta's Pocket Gopher (Thomomys bottae) & $\mathrm{D}$ & $\mathrm{C}$ \\
\hline \multicolumn{3}{|l|}{ Pocket Mice and Kangaroo Rats (Rodentia: Family Heteromyidae) } \\
\hline San Diego Pocket Mouse (Chaetodipus fallax) & $\mathrm{D}$ & M, C \\
\hline Long-tailed Pocket Mouse (Chaetodipus formosus) & $\mathrm{D}$ & M, C \\
\hline Sonoran Desert Pocket Mouse (Chaetodipus penicillatus) & $\mathrm{D}$ & M, C \\
\hline
\end{tabular}


Spiny Pocket Mouse (Chaetodipus spinatus)

Desert Kangaroo Rat (Dipodomys deserti)

Merriam's Kangaroo Rat (Dipodomys merriami)

Chisel-toothed Kangaroo Rat (Dipodomys microps)

Little Pocket Mouse (Perognathus longimembris)

Mice, Rats, and Voles (Rodentia: Family Muridae)

California Vole (Microtus californicus)

House Mouse (Mus musculus)

White-throated Woodrat (Neotoma albigula)

Big-eared Woodrat (Neotoma macrotis)

Desert Woodrat (Neotoma lepida)

Southern Grasshopper Mouse (Onychomys torridus)

Brush Mouse (Peromyscus boylii)

Canyon Mouse (Peromyscus crinitus)

Cactus Mouse (Peromyscus eremicus)

Deer Mouse (Peromyscus maniculatus)

Pinyon Mouse (Peromyscus truei)

Western Harvest Mouse (Reithrodontomys megalotis)

Dogs, Foxes, and Wolves (Carnivora: Family Canidae)

Coyote (Canis latrans)

Common Gray Fox (Urocyon cinereoargenteus)

Kit Fox (Vulpes macrotis)

Bears (Carnivora: Family Ursidae)

Black Bear (Ursus americanus)

Raccoons, Ringtails, and Coatis (Carnivora: Family Procyonidae)

Ringtail (Bassariscus astutus)

Northern Raccoon (Procyon lotor)

Weasels, Otters, and Badgers (Carnivora: Family Mustelidae)

Long-tailed Weasel (Mustela frenata)

Badger (Taxidea taxus)

Skunks (Carnivora: Family Mephitidae)

Western Spotted Skunk (Spilogale gracilis)

Cats (Carnivora: Family Felidae)

Bobcat (Lynx rufus)

Mountain Lion (or Puma) (Puma concolor)

Horses and Asses (Perissodactyla: Family Equidae)

Feral Ass (Equus asinus)

Deer (Artiodactyla: Family Cervidae)

Mule (or Black-tailed) Deer (Odocoileus hemionus)

Cattle, Antelope, Sheep, and Goats (Artiodactyla: Family Bovidae)

Bighorn (or Mountain) Sheep (Ovis canadensis)
$\mathrm{D}$

D

D

Historic?

D

Potential (M?)

$\mathrm{D}$ ?

L

D

$\mathrm{D}$

$\mathrm{D}$

D

$\mathrm{D}$

$\mathrm{D}$

D

$\mathrm{D}$

D

D

$\mathrm{D}$

D

$\mathrm{D}$

D

L

D

Potential (M)

Potential (H?)

L

D

M, L

D

S, L

D

M, L

D

M, L

D

L

D

M, L

D

M, L 
Appendix 3. Hypothetical mammal species list for Lake Mead National Recreation Area, Arizona / California. This list was prepared at the outset of an inventory study conducted from $2002-2006$, and served as a guide for targeting field sampling, and as a point of comparison for inventory completeness. Under Status, "D" indicates species has been documented from park, and " $L$," "M," and " $H$ " denote low, medium, and high potential of occurrence. Under evidence, " $L "=$ literature record and " $M$ " = museum specimen.

Common name (Scientific name)

Park Status

Evidence

Shrews (Insectivora: Family Soricidae)

Crawford's Desert Shrew (Notiosorex crawfordi)

$\mathrm{D}$

Potential (M)

New World Leaf-nosed Bats (Chiroptera: Family Phyllostomidae)

California Leaf-nosed Bat (Macrotus californicus)

Vesper Bats (Chiroptera: Family Vespertilionidae)

Pallid Bat (Antrozous pallidus)

Townsend's Big-eared Bat (Corynorhinus townsendii)

Big Brown Bat (Eptesicus fuscus)

Spotted Bat (Euderma maculatum)

Allen's Big-eared Bat (Idionycteris phyllotis)

Silver-haired Bat (Lasionycteris noctivagans)

Western Red Bat (Lasiurus blossevillii)

Hoary Bat (Lasiurus cinereus)

Western Yellow Bat (Lasiurus xanthinus)

California Myotis (Myotis californicus)

Western Small-footed Myotis (Myotis ciliolabrum)

Long-eared Myotis (Myotis evotis)

Fringed Myotis (Myotis thysanodes)

Cave Myotis (Myotis velifer)

Long-legged Myotis (Myotis volans)

Yuma Myotis (Myotis yumanensis)

Western Pipistrelle (Pipistrellus hesperus)

Free-tailed Bats (Chiroptera: Family Molossidae)

Western Mastiff (or Western Bonneted) Bat (Eumops perotis)

Pocketed Free-tailed Bat (Nyctinomops femorosaccus)

Big Free-tailed Bat (Nyctinomops macrotis)

Brazilian Free-tailed Bat (Tadarida brasiliensis)

Hares and Rabbits (Lagomorpha: Family Leporidae)

Black-tailed Jackrabbit (Lepus californicus)

Desert Cottontail (Sylvilagus audubonii)

Eastern cottontail (Sylvilagus floridanus)

Mountain (or Nuttall's) Cottontail (Sylvilagus nuttallii)

Squirrels (Rodentia: Family Sciuridae)

Harris's Antelope Squirrel (Ammospermophilus harrisii)

White-tailed Antelope Squirrel (Ammospermophilus leucurus)

Cliff Chipmunk (Neotamias dorsalis)

Least Chipmunk (Neotamias minimus)
$\mathrm{D}$

$\mathrm{D}$

$\mathrm{D}$

$\mathrm{D}$

Potential (M)

$\mathrm{D}$

Potential (H)

Potential (M)

Potential (H)

Potential (M)

$\mathrm{D}$

Potential (H)

Potential (M?)

Potential (H)

Potential (M)

Potential (H)

D

$\mathrm{D}$

D

Potential (M)

D

D

D

D

Potential (L)

Status?

D

D

D

Potential (M?)
L

L

L

L

L

L

L

L

M, L

L

M, L

M, L, S

L

L

L

L

L, S

L

M, C

M,

M, C, S 
Round-tailed Ground Squirrel (Spermophilus tereticaudus)

Pocket Gophers (Rodentia: Family Geomyidae)

Botta's Pocket Gopher (Thomomys bottae)

Pocket Mice and Kangaroo Rats (Rodentia: Family Heteromyidae)

Long-tailed Pocket Mouse (Chaetodipus formosus)

Rock Pocket Mouse (Chaetodipus intermedius)

Sonoran Desert Pocket Mouse (Chaetodipus penicillatus)

Spiny Pocket Mouse (Chaetodipus spinatus)

Desert Kangaroo Rat (Dipodomys deserti)

Merriam's Kangaroo Rat (Dipodomys merriami)

Chisel-toothed Kangaroo Rat (Dipodomys microps)

Ord's Kangaroo Rat (Dipodomys ordii)

Arizona Pocket Mouse (Perognathus amplus)

Little Pocket Mouse (Perognathus longimembris)

Great Basin Pocket Mouse (Perognathus parvus)

Beavers (Rodentia: Family Castoridae)

American Beaver (Castor canadensis)

Mice, Rats, and Voles (Rodentia: Family Muridae)

House Mouse (Mus musculus)

White-throated Woodrat (Neotoma albigula)

Bushy-tailed Woodrat (Neotoma cinerea)

Plateau and Sheep Mountains in NV)

Arizona Woodrat (Neotoma devia)

Desert Woodrat (Neotoma lepida)

Common Muskrat (Ondatra zibethicus)

Northern Grasshopper Mouse (Onychomys leucogaster)

Southern Grasshopper Mouse (Onychomys torridus)

Brush Mouse (Peromyscus boylii)

Canyon Mouse (Peromyscus crinitus)

Cactus Mouse (Peromyscus eremicus)

Deer Mouse (Peromyscus maniculatus)

Pinyon Mouse (Peromyscus truei)

Western Harvest Mouse (Reithrodontomys megalotis)

Arizona Cotton Rat (Sigmodon arizonae)

New World Porcupines (Rodentia: Family Erethizontidae)

North American Porcupine (Erethizon dorsatum)

Dogs, Foxes, and Wolves (Carnivora: Family Canidae)

Coyote (Canis latrans)

Gray Wolf (Canis lupus)

Common Gray Fox (Urocyon cinereoargenteus)

Kit Fox (Vulpes macrotis)
$\mathrm{D}$ ?

$\mathrm{D}$

S

D

M,

D

D

M, C

$\mathrm{D}$

$\mathrm{D}$

$\mathrm{D}$

D

D

Potential (H)

Potential (M)

D

D

Potential (H)

M,

C

$\mathrm{M}$,

M,

C

M, C

$\mathrm{M}, \mathrm{C}$
C

D

Potential (L / M)

(Kaibab

M, C

C

$<$ Check

Potential (H)

D

D

D

D

D

D

D

Potential (M)

D

L

D

L

Historic

D

L

D L 
Raccoons, Ringtails, and Coatis (Carnivora: Family Procyonidae)

Ringtail (Bassariscus astutus)

$\mathrm{D}$

$\mathrm{D}$

D / Historic

$\mathrm{D}$

Potential (H)

$\mathrm{D}$

$\mathrm{D}$

Potential $(\mathrm{H})$

$\mathrm{D}$

L

L

$\mathrm{L}$

$\mathrm{L}$

L

L
M, L M, L

L, S

$\mathrm{L}$

L, S

Historic?

L

D L, S

Unconfirmed / Historic L

D

L, S 
Appendix 4. Hypothetical mammal species list for Manzanar National Historic Site, California. This list was prepared at the outset of an inventory study conducted from $2002-2006$, and served as a guide for targeting field sampling, and as a point of comparison for inventory completeness. Under Status, "D" indicates species has been documented from park, and " $L$," " $M$," and " $H$ " denote low, medium, and high potential of occurrence. Under evidence, "L" = literature record and "M" = museum specimen.

Common name (Scientific name)

Park Status

Evidence

Shrews (Insectivora: Family Soricidae)

Water Shrew (Sorex palustris)

Potential (M)

Moles (Insectivora: Family Talpidae)

Broad-footed Mole (Scapanus latimanus)

Potential (M)

Vesper Bats (Chiroptera: Family Vespertilionidae)

Pallid Bat (Antrozous pallidus)

Potential (M)

Big Brown Bat (Eptesicus fuscus)

Potential $(\mathrm{H})$

Silver-haired Bat (Lasionycteris noctivagans)

Potential $(\mathrm{H})$

Western Red Bat (Lasiurus blossevillii)

Potential $(\mathrm{H})$

Hoary Bat (Lasiurus cinereus)

Potential $(\mathrm{H})$

California Myotis (Myotis californicus)

Potential (H)

Western Small-footed Myotis (Myotis ciliolabrum)

Potential (M)

Little Brown Myotis (Myotis lucifugus)

Potential $(\mathrm{H})$

Fringed Myotis (Myotis thysanodes)

Potential (M)

Yuma Myotis (Myotis yumanensis)

Potential (M)

Western Pipistrelle (Pipistrellus hesperus)

Potential (M)

Free-tailed Bats (Chiroptera: Family Molossidae)

Brazilian Free-tailed Bat (Tadarida brasiliensis)

Potential (H)

Hares and Rabbits (Lagomorpha: Family Leporidae)

Black-tailed Jackrabbit (Lepus californicus)

$\mathrm{D}$

$\mathrm{D}$

S

Desert Cottontail (Sylvilagus audubonii)

Squirrels (Rodentia: Family Sciuridae)

White-tailed Antelope Squirrel (Ammospermophilus leucurus)

$\mathrm{D}$

C, S

California Ground Squirrel (Spermophilus beecheyi)

$\mathrm{D}$

$\mathrm{S}$

Least Chipmunk (Neotamias minimus)

Potential (L)?

Pocket Gophers (Rodentia: Family Geomyidae)

Botta's Pocket Gopher (Thomomys bottae)

$\mathrm{D}$

Pocket Mice and Kangaroo Rats (Rodentia: Family Heteromyidae)

Merriam's Kangaroo Rat (Dipodomys merriami)

D

C

Chisel-toothed Kangaroo Rat (Dipodomys microps)

Potential (M)

Panamint Kangaroo Rat (Dipodomys panamintinus)

$\mathrm{D}$

D

C

Little Pocket Mouse (Perognathus longimembris)

Potential (M)

C

Great Basin Pocket Mouse (Perognathus parvus)

Potential (L)?

American Beaver (Castor canadensis)

Mice, Rats, and Voles (Rodentia: Family Muridae)

California Vole (Microtus californicus)

D

C 
Long-tailed Vole (Microtus longicaudus)

House Mouse (Mus musculus)

Desert Woodrat (Neotoma lepida)

Southern Grasshopper Mouse (Onychomys torridus)

Brush Mouse (Peromyscus boylii)

Deer Mouse (Peromyscus maniculatus)

Pinyon Mouse (Peromyscus truei)

Western Harvest Mouse (Reithrodontomys megalotis)

New World Porcupines (Rodentia: Family Erethizontidae)

North American Porcupine (Erethizon dorsatum)

Dogs, Foxes, and Wolves (Carnivora: Family Canidae)

Coyote (Canis latrans)

Gray Fox (Urocyon cinereoargenteus)

Kit Fox (Vulpes macrotis)

Raccoons, Ringtails, and Coatis (Carnivora: Family Procyonidae)

Ringtail (Bassariscus astutus)

Northern Raccoon (Procyon lotor)

Weasels, Otters, and Badgers (Carnivora: Family Mustelidae)

Long-tailed Weasel (Mustela frenata)

Badger (Taxidea taxus)

Skunks (Carnivora: Family Mephitidae)

Striped Skunk (Mephitis mephitis)

kill)

Western Spotted Skunk (Spilogale gracilis)

Cats (Carnivora: Family Felidae)

Bobcat (Lynx rufus)

Horses and Asses (Perissodactyla: Family Equidae)

Feral Ass (Equus asinus)

Deer (Artiodactyla: Family Cervidae)

Elk (Cervus canadensis; Tule Elk - C. c. nannodes)

Mule Deer (Odocoileus hemionus)
Potential (M)

Potential $(\mathrm{H})$

D

C

D

D

D

Potential (L)?

D

C

Potential (M)

D

Potential (H)

D

Potential (L)?

D

Potential (M)?

Potential (H)

D

Potential (M)?

Potential (H)

Status?

D

D?
S

S

S (road-

S

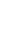

C

C 
Appendix 5. Hypothetical mammal species list for Mojave National Preserve, California. This list was prepared at the outset of an inventory study conducted from $2002-2006$, and served as a guide for targeting field sampling, and as a point of comparison for inventory completeness. Under Status, "D" indicates species has been documented from park, and " $L$," " $M$," and " $H$ " denote low, medium, and high potential of occurrence. Under evidence, "L" = literature record and " $M$ " = museum specimen.

Common name (Scientific name)

Park Status

Evidence

Shrews (Insectivora: Family Soricidae)

Crawford's Desert Shrew (Notiosorex crawfordi)

$\mathrm{D}$

Potential (M)

Vesper Bats (Chiroptera: Family Vespertilionidae)

Pallid Bat (Antrozous pallidus)

Townsend's Big-eared Bat (Corynorhinus townsendii)

Big Brown Bat (Eptesicus fuscus)

Spotted Bat (Euderma maculatum)

Western Red Bat (Lasiurus blossevillii)

Hoary Bat (Lasiurus cinereus)

California Myotis (Myotis californicus)

Western Small-footed Myotis (Myotis ciliolabrum)

Fringed Myotis (Myotis thysanodes)

Long-legged Myotis (Myotis volans)

Yuma Myotis (Myotis yumanensis)

Western Pipistrelle (Pipistrellus hesperus)

Free-tailed Bats (Chiroptera: Family Molossidae)

Western Mastiff (or Western Bonneted) Bat (Eumops perotis)

Pocketed Free-tailed Bat (Nyctinomops femorosaccus)

Big Free-tailed Bat (Nyctinomops macrotis)

Brazilian Free-tailed Bat (Tadarida brasiliensis)

Hares and Rabbits (Lagomorpha: Family Leporidae)

Black-tailed Jackrabbit (Lepus californicus)

Desert Cottontail (Sylvilagus audubonii)

Mountain (or Nuttall's) Cottontail (Sylvilagus nuttallii)

Squirrels (Rodentia: Family Sciuridae)

White-tailed Antelope Squirrel (Ammospermophilus leucurus)

Panamint Chipmunk (Neotamias panamintinus)

Round-tailed Ground Squirrel (Spermophilus tereticaudus)

Rock Squirrel (Spermophilus variegatus)

Pocket Gophers (Rodentia: Family Geomyidae)

Botta's Pocket Gopher (Thomomys bottae)

Pocket Mice and Kangaroo Rats (Rodentia: Family Heteromyidae)

San Diego Pocket Mouse (Chaetodipus fallax)

Long-tailed Pocket Mouse (Chaetodipus formosus)

Sonoran Desert Pocket Mouse (Chaetodipus penicillatus)

Spiny Pocket Mouse (Chaetodipus spinatus)
$\mathrm{D}$

$\mathrm{D}$

$\mathrm{D}$

Potential (H)

Potential (M)

$\mathrm{D}$

$\mathrm{D}$

D

D

D

Potential (H)

D

Potential (H)

Potential (M)

Potential (M)

D

L

D L

D

Status?

L, S

$\mathrm{D}$ ? (see)

D

D

D

D

D

L

D C

D C, L

D M, C

D C, L 
Desert Kangaroo Rat (Dipodomys deserti)

Merriam's Kangaroo Rat (Dipodomys merriami)

Chisel-toothed Kangaroo Rat (Dipodomys microps)

Panamint Kangaroo Rat (Dipodomys panamintinus)

Little Pocket Mouse (Perognathus longimembris)

Great Basin Pocket Mouse (Perognathus parvus)

Mice, Rats, and Voles (Rodentia: Family Muridae)

Bushy-tailed Woodrat (Neotoma cinerea)

Desert Woodrat (Neotoma lepida)

Big-eared Woodrat (Neotoma macrotis)

Southern Grasshopper Mouse (Onychomys torridus)

Brush Mouse (Peromyscus boylii)

Canyon Mouse (Peromyscus crinitus)

Cactus Mouse (Peromyscus eremicus)

Deer Mouse (Peromyscus maniculatus)

Pinyon Mouse (Peromyscus truei)

Western Harvest Mouse (Reithrodontomys megalotis)

New World Porcupines (Rodentia: Family Erethizontidae)

North American Porcupine (Erethizon dorsatum)

Dogs, Foxes, and Wolves (Carnivora: Family Canidae)

Coyote (Canis latrans)

Gray Wolf (Canis lupus)

Common Gray Fox (Urocyon cinereoargenteus)

Kit Fox (Vulpes macrotis)

Raccoons, Ringtails, and Coatis (Carnivora: Family Procyonidae)

Ringtail (Bassariscus astutus)

Weasels, Otters, and Badgers (Carnivora: Family Mustelidae)

Badger (Taxidea taxus)

Skunks (Carnivora: Family Mephitidae)

Striped Skunk (Mephitis mephitis)

Western Spotted Skunk (Spilogale gracilis)

Cats (Carnivora: Family Felidae)

Bobcat (Lynx rufus)

Mountain Lion (or Puma) (Puma concolor)

Horses and Asses (Perissodactyla: Family Equidae)

Feral Ass (Equus asinus)

Wild Horse (Equus caballus)

Deer (Artiodactyla: Family Cervidae)

Mule (or Black-tailed) Deer (Odocoileus hemionus)

Cattle, Antelope, Sheep, and Goats (Artiodactyla: Family Bovidae)

Bighorn (or Mountain) Sheep (Ovis canadensis)

Domestic Cattle (Bos taurus)

\section{D}

D

D

D

D

Potential (M)

Potential (M)

$\mathrm{D}$

D

D

D

D

$\mathrm{D}$

D

$\mathrm{D}$

D

$\mathrm{D}$

D

Historic

D

D

D

D

Potential (M)

D

D

D

D

D

D

D

D
L

L

L

L, S

L

L

C, L

C, L

L

C, L

C, L

C, L

L

L

M, C, L

C, L

C, L

C, L

M, C, L

L

L

S, L

L

L

L

L

L

L, S

L, S 